\title{
CHRONICLE OF EVENTS AND INCIDENTS RELATING TO ASIA WITH RELEVANCE TO INTERNATIONAL LAW
}

\author{
July 1994-June 1995
}

\section{Ko Swan $\operatorname{Sik}^{*}$}

with contributions from WAN ARFAH HAMZAH (Kuala Lumpur) and KRIANGSAK KITTICHAISAREE (Bangkok/Washington D.C.)

\section{TABLE OF HEADINGS}

Air traffic

Aliens

Arms sales and supplies

Asian Development Bank (ADB)

Asian Pacific Economic Cooperation forum (APEC)

Association of South East Asian Nations (ASEAN)

Asylum

Borders, border disputes and border incidents

Broadcasting

Cambodia

Chemicals and chemical weapons

Civil war

Compensation

Debts

Development aid

Diplomatic and consular inviolability

Diplomatic and consular protection

Diplomatic and consular relations

Disarmament and arms control

Dissidents

Divided states: China

Divided states: Korea

East Asia Economic Caucus (EAEC)

Economic cooperation and assistance

Emergency aid

Environmental pollution and protection
Espionage

Exclusive economic zone

Fisheries

Foreign investment and transnational contracts

General Agreement on Tariffs and Trade (GATT)

Group of 77

Hong Kong

Hot pursuit

Immigration and emigration

Insurgents

Intellectual property

Inter-state relations: general aspects

(Non-) Interference

International criminal law

International Monetary Fund (IMF)

International trade

Iraq-Kuwait War

Japan's military role

Joint development and joint ventures

Judicial assistance

Jurisdiction

Korean War

Labour

Loans

Migrant workers

Military alliances

Military cooperation

\footnotetext{
* General Editor
}

Asian Yearbook of International Law, Volume 5 (Ko Swan Sik et al., eds.; 90-411-0375-9

() 1997 Kluwer Law International; printed in the Netherlands), pp. 383-508 
Minorities

Missile technology

Narcotics problem

Nationality

Naval incidents

Non-Aligned Movement (NAM)

Nuclear capability

Oil and gas

Passports and visas

Piracy

Recognition

Refugees

Regional security

Rivers

Sanctions

Sea traffic

Settlement of disputes

South Asian Association for Regional

Cooperation (SAARC)

Southeast Asia Community
Space activities

Specific territories within a state:

East Timor

Specific territories within a state:

Kashmir

Specific territories within a state:

Tibet

Taxation

Territorial claims and disputes

Territorial integrity

Territorial waters

Terrorism

Transit

United Nations

Unrecognized entities

(Non-)Use of force

Vietnam War

Weapons

World Trade Organization (WTO)

World War II

\section{AIR TRAFFIC}

\section{Japan-US dispute on air cargo flight routes}

The two countries failed to agree over a US request for new air cargo flight routes to Asia under the 1952 US-Japanese Air Transport Services Agreement. At the centre of the dispute are 'beyond rights', i.e. permission for US lines, particularly Federal Express Corp., to fly to third countries, particularly to FedEx's new transfer facility at Subic Bay in the Philippines, via Japanese cities.

The Japanese side turned down the request, classifying it as excessive. Japan insisted on prior amendment of the 1952 treaty because of its 'inequities'. It alleged it had been trying to renegotiate the treaty for twenty years but had been rebuffed by the US. Under the treaty three US airlines (among which FedEx) were given virtually unlimited rights to fly not only from the US to Japan, but also onward from Japan to other Asian countries. It was reported that United Airlines and Northwest Airlines got a third of their profit from routes that go through Japan. Japanese airlines, in return, had only limited rights to fly beyond the US. The Japanese position is that when it signed the treaty in 1952 it had just been freed from US occupation and was not in a good bargaining position. Furthermore, most air passengers were then Americans while nowadays most passengers flying between the US and Japan are Japanese, yet Japanese airlines still have only a $30 \%$ share of the traffic. In addition, because of the limited range of airplanes in those days, the American carriers needed to make a landing in Japan on their way to other Asian destinations. Besides, under the 1952 treaty Japanese airlines flying into the US only have onward rights from San Francisco. Japan should 
like to scrap the restrictions on the places that can be served by either side and instead reach a deal on numbers of flights.

Apart from the revision of the 1952 treaty, Japan also held that the new FedEx routes would upset the air-cargo market balance in the Pacific region. FedEx's response was that Japanese carriers (such as Nippon Cargo Airlines) had a 5-to-1 advantage in weight of cargo shipped between Asia and the US. In retaliation of the Japanese refusal to grant the requested flight routes, the US thereupon started preparing sanctions on Japanese air cargo operations in the US.

Compared to the US-Japanese dispute on automobiles (see: International trade) the aviation case showed a reversal of roles: each side was here seeking a kind of solution which it found unacceptable in the automobile case. In the background of the dispute is the effort of the US to win 'open skies', i.e. the deregulation of air traffic, whereas Asian airlines fear that they would be unable to compete with US carriers which are in a better position to draw on their huge home market. (IHT 05, 16 and 21-06-95; FEER 08-06-95 p. 56)

\title{
Hong Kong-Australia dispute over passenger quota
}

Qantas Airways had asked the Hong Kong Supreme Court to undo a government decision of April 1995 limiting to 50 percent capacity the number of passengers that Qantas could pick up in Hong Kong on its onward flights to Bangkok and Singapore. It contended that its Bangkok and Singapore services were in compliance with current air-traffic agreements. Hong Kong argued that Qantas had abused a Hong KongAustralia air-service agreement of 1991 by taking too many passengers on its onward flights within Asia. Australia responded to the Hong Kong restrictions by announcing that access of Cathay Pacific Airways to Australia would be put under review for the period after 30 June, whereupon Hong Kong threatened Qantas with a loss of Hong Kong landing rights. (IHT 16 and 22-06-95)

A settlement of the conflict was postponed when the two sides withdrew their threats of sanctions and agreed to review their mutual aviation permits by year-end. (IHT 27-06-95)

\author{
ALIENS \\ (see also: Immigration; Inter-state relations: general aspects at p. 435; Migrant \\ workers)
}

\section{Release of convicted spy in Iran}

A German engineer who had been sentenced to death by an Iranian court after having been convicted of spying for Iraq during the 1980-1988 war, was pardoned and released after five years in prison. The release resulted from talks between German officials and the Iranian Foreign Minister during the latter's visit to Germany in midJune 1994. (IHT 04-07-94) 


\section{Aliens barred from entry for foreign policy reasons}

Thailand barred foreign activists from entering the country to attend human-rights conferences on Timor and Myanmar scheduled to coincide with the ASEAN Foreign Ministers' Conference in July 1994. (FEER 28-07-94 p. 23)

\section{Deportation of undesired alien from Thailand}

Thailand on 2 September 1994 detained and deported to Malaysia the (Malaysian) head of the Islamic sect 'Arqam', which was banned in Malaysia. (IHT 3/4-09-94) Upon arrival in Malaysia Mr. ABUYA ASHAARI MUHAMMAD was taken into police custody under the Malaysian Internal Security Act. (IHT 06-09-94)

\section{Voting rights for aliens}

The Japanese prime minister expressed support for the right of permanent foreign residents to vote in local elections. He said that since foreign residents live and pay taxes in Japan, they deserve to voice their opinion.

Meanwhile the Japanese Supreme Court ruled that the Constitution did not exclude the possibility of a right for foreign residents to vote in such elections. So far the Public Offices Election Law and the Local Government Law stipulate that only people of Japanese nationality are eligible to vote and run for office. (IHT 02-03-95)

\section{Kazakhstan-Russia Treaty on the legal status of each other's citizens}

The two countries concluded a treaty on 20 January 1995 on the legal status of citizens of one party "who reside permanently in the territory" of the other party.

The preamble refers to (1) the wish of the parties to offer their citizens who reside in the other party's territory a legal status "that is as close as possible to the legal status of the citizens of the other Party, in particular as regards civil, political, social, economic, labour, cultural and other rights", (2) the Kazakhstan-Russia Treaty on Friendship, Cooperation and Mutual Assistance of 25 May 1992 and (3) the Memorandum of 28 March 1994 on "basic principles for settling questions relating to the citizenship and legal status" of each other's citizens who reside in the territory of the other party.

The treaty, consisting of 16 articles, excludes simultaneous permanent residence in both countries for citizens of either party (Art. 1). The category of persons covered by the Treaty "shall enjoy the protection of the two Parties" (Art. 3 para. 2), and "shall enjoy the same rights and freedoms and be bound by the same obligations as citizens of the Party of residence" except various rights relating to political, representative, judicial and security functions (Art. 4). (UN doc. A/50/83)

\section{Vietnamese in Germany}

About 60,000 Vietnamese were living legally in Germany, among whom were the former 'boat people' who began arriving in West Germany in the early 1980s. 
In the past decades possibly 100,000 Vietnamese were admitted by East Germany as students or contract workers. The arrangement terminated with German reunification, and the German government offered a bonus and free plane tickets home for those willing to go; more than 50,000 accepted the offer. However, at least 15,000 decided to stay, taking advantage of temporary residence permits valid for the duration of their contracts. Besides thousands slipped back to Germany as illegal aliens or as asylum seekers. Due to the tough new standards fewer than one percent would actually obtain asylum. The result was an estimated 40,000 illegal Vietnamese in Germany.

On 6 January 1995 the German and Vietnamese governments reached agreement, pledging early action on, inter alia, "Vietnamese citizens who stay in Germany without the legal right to do so". Germany promised to resume aid and provide more exportguarantees to German firms, and gave the green light to a Euro-Vietnamese cooperation agreement. This agreement called for "the orderly return of Vietnamese workers" about which different interpretations existed.

In April 1995 an agreement was reached between the two countries: Germany would provide $\$ 142$ million in development aid and Vietnam would repatriate 40,000 Vietnamese over the next five years. (FEER 29-09-94 p. 30; 09-02-95 p. 28; IHT 12$01-95,17 / 18-06-95)$

\section{Arrest of US citizen in China}

A US citizen was arrested and detained in June 1995 when he entered the Chinese province of Xinjiang from Kazakhstan. The arrest took place for illegal entries made in 1994 and illegal activities during these stays. China refused to disclose the whereabouts of the detained person and the US accused China of denying US officials access to him as required under a relevant international agreement. (IHT 28, 29 and 30-06-95)

\section{ARMS SALES AND SUPPLIES}

\section{US sale of combat aircraft to Asia}

It was announced that Singapore was to buy 18 F-16 fighter aircraft from the US company Lockheed, to be delivered as of 1998.

The company stated that among its nine foreign customers currently waiting for execution of orders, five were Asian (Singapore, Thailand, Taiwan, South Korea and Pakistan). (IHT 11-07-94; FEER 21-07-94 p. 13)

\section{US Patriot air defence system and warships for Taiwan}

The Taiwanese defence ministry announced that Taiwan would purchase an air defence system based on the Patriot missile. The first delivery would be in 1996. (FEER 14-07-94 p. 13, 11-08-94 p. 13) It was later reported that Taiwan had acquired four modernized former US mine sweepers. (IHT 06-02-95) 


\section{US limits to arms sales to Indonesia}

In order to convey a 'strong message' to Indonesia on human rights, the US Senate on 14 July 1994 voted to restrict small arms sales by way of an amendment to a foreign aid measure under consideration, unless the Secretary of State determines that there has been significant progress on human rights in East Timor. (IHT 16/17-07-94,FEER 2807-94 p. 18) In 1994 the US Defense Department authorized weapons sales to Indonesia worth an estimated $\$ 10.7$ million, in addition to an estimated $\$ 90$ million in US arms licensed for sale by the State Department. (IHT 22-03-95)

\section{Russian rockets for India}

Russia agreed to sell seven cryogenic (low temperature fuel) rocket engines to India but would not transfer their technology. (FEER 04-08-94 p. 13)

\section{Volume of arms sales to Third World countries}

According to the (US) "Congressional Research Service" overall sales fell 22 percent in 1993, to $\$ 20.4$ billion from $\$ 26.2$ billion in 1992 . The fall started with the end of the Cold War.

However, sales from the US rose to $\$ 14.8$ billion in 1993 from $\$ 14.6$ billion in 1992, its share rising from 56 percent to 73 percent. (IHT 03-08-94)

\section{French sale of submarines and missiles to Pakistan}

Pakistan signed an agreement with France on 21 September 1994 to buy three Agosta 90-B submarines including torpedoes and anti-ship missiles and transfer of technology. The deal included a French pledge not to sell the same submarines and weapons to India. (IHT 22-09-94)

\section{Chinese weapons sale to Myanmar}

It was reported by Jane's Defence Weekly that Myanmar had signed a (second) defence contract with China in November 1994, worth $\$ 400$ million. A previous package was worth $\$ 1.2$ billion. (IHT 01-12-94; FEER 01-12-94 p. 12)

\section{Israeli supply to Asia}

Israel began selling weapons to Asia in the 1950 s but sales increased steeply when the arms manufacturers were confronted with domestic procurement cuts and shrinking traditional markets in Western Europe, the US and South America.

Most of the increase were accounted by sales to China and Southeast Asia. It was reported that China bought around $\$ 3$ billion of Israeli arms over the last ten years. Ironically, Israeli arms exports had also made inroads into the Taiwan market by licensing the production of anti-ship and other missiles. 
So far as other Asian countries are concerned, Singapore was being mentioned as a most faithful Israeli client. Singapore organizes its entire military strategy on the Israeli model. Besides, inter alia, the government-owned IAI was negotiating a $\$ 300$ million sale of Kfir fighters to the Philippines and sold Arava reconnaissance aircraft to Thailand. (FEER 19-01-95 p. 27)

\section{US arms for Cambodia}

It was reported that the US would consider supplying weapons to Cambodia after its armed forces had been reformed. (IHT 30-01-95)

\section{Russian submarines for China}

It was reported that China had bought four patrol submarines from Russia in November 1994 and that the first one had already been delivered. (IHT 10-02-95; FEER 23-02-95 p. 13)

\section{Polish tanks for Iran}

Despite US objections Poland planned to go ahead with its sale of more than hundred T-72 tanks and to continue the already started deliveries. The sale appears to be driven more by domestic considerations than by foreign policy. (IHT 18-05-95)

\section{South African arms sales to Malaysia}

Malaysia concluded two deals with South Africa for the purchase of warfare equipment worth RM71.6 million and for the procurement of grenade launchers and grenades worth RM508,000. (Star 25-05-95)

\section{ASIAN DEVELOPMENT BANK (ADB)}

\section{Need of increased financial support by newly rich Asian countries}

Echoing a sentiment expressed by Bank officials and Japan, the US Assistant Treasury Secretary said at the annual meeting of the ADB that newly prosperous economies as Singapore, Taiwan, South Korea, should contribute more to finance future development bank initiatives. (IHT 03 and 04-05-95)

\section{ASIAN-PACIFIC ECONOMIC COOPERATION forum (APEC)}

(see also: Association of South East Asian Nations)

\section{Regional trade liberalization}

Trade ministers from Asia-Pacific countries met in Jakarta in early October 1994 
to discuss regional trade liberalization in goods and services in preparation of the annual ministerial conference in November. The meeting considered a recommendation of the so-called Eminent Persons Group (EPG, see infra p. 392), comprising business leaders, economists and former officials. The recommendation contained a target for achieving free trade in 2020, by way of a phased introduction, taking account of the widely varying levels of development among APEC members. According to the proposed plan developed countries should eliminate trade barriers by 2010 , newly industrialized economies by 2015 and developing countries by 2020 .

It was reported that some countries, including Japan, China, South Korea and Malaysia were wary of accepting a fixed time-table, while Malaysia also asserted that the plan could allow powerful states to dictate economic terms to smaller countries. (IHT 06-10-94; FEER 15-09-94 p. 77) A Chinese foreign ministry statement said that China wanted more concrete assurances about its trade and economic status as part of the accord, although China approved of trade liberalization in the Asia-Pacific region as a long-term goal. (IHT 15/16 and 26-10-94) Later China said it could endorse the plan to liberalize trade by 2020 provided it was applied in a 'flexible' way and took account of differences between developed and developing countries. (IHT 15/16 and 26-10-94, 12/13-11-94)

In trying to implement the plans contained in the Bogor Declaration (infra) substantial differences between the members of APEC became apparent at a meeting among officials at Fukuoka in February 1995. The differences concerned the question how to liberalize import barriers and whether to extend the benefits to third states without reciprocal concessions. A second meeting was planned for April in Singapore. (IHT 17-03-95)

On 20 June 1995 the Japanese executive director of APEC accused the US of disrupting preparations for the annual summit meeting by backing out of the proposed scheme for a regional free-trade mechanism as adopted in the Bogor Declaration. It was said that the US preferred a short-term binding commitment to achieve free trade to a non-binding system spread out over a period of more than twenty years which would enable heavily protected East Asian economies to avoid taking real action to open their markets. The fundamental difference between the US and Asia centered on whether APEC should develop primarily as an organization for reducing trade barriers, or as a club for promoting regional growth through more diversified means. It was also said that the Asian partners were particularly unhappy with the US stress on reciprocal exchanges of trade concessions with non-members, preferring an open non-reciprocal system instead. (IHT 21 and 26-06-95; FEER 15-09-94 p. 77)

\section{Investment Code}

The 18 APEC states endorsed a common investment code on 11 November 1994. The code covers such issues as investment incentives, expropriation and compensation, repatriation and convertibility of profits, settlement of disputes, entry and residence of staff, and avoidance of double taxation. The next step would be for APEC members to incorporate the principles of the investment code into their domestic laws, while the final step would be to make them legally binding among the APEC members. (IHT $12 / 13-11-94)$ 


\section{Declaration of Common Resolve (Bogor Declaration)}

The members of APEC committed themselves on 15 November 1994, with Malaysian reservations, to achieve free and open trade and investment no later than 2020 but no commitments were made to start rounds of negotiations on the cuts in trade barriers.

Among the features of the Declaration were:

- a distinction between industrialized economies which would achieve the goal no later than the year 2010 and developing economies no later than 2020;

- particular attention to be given to trade between APEC members and non-APEC developing countries to ensure that the latter would also benefit from the trade and investment liberalization in conformity with GATT/WTO provisions;

- APEC economies that are ready to initiate and implement a cooperative arrangement may proceed to do so while those not yet ready to participate may join at a later date. (IHT 16-11-94; NST and Star 17-11-94)

\section{ASSOCIATION OF SOUTH EAST ASIAN NATIONS (ASEAN) (see also: United Nations)}

\section{Attendance of the annual foreign ministers meeting by prospective members}

The foreign minister of Myanmar attended the Foreign Ministers' Meeting in July 1994 as a guest of the host country (Thailand). For two years, plans by ASEAN to invite Myanmar had been thwarted by Malaysia and Indonesia who were inspired by the flight of members of the Muslim Rohingya community from Myanmar to Bangladesh.

The foreign ministers of Vietnam and Laos attended the meeting as observers, and the Cambodian foreign minister as a guest of ASEAN.

While all ASEAN members expressed their expectation of these four countries being included in a truly regional community of nations of Southeast Asia in the foreseeable future, the US and Australia recently expressed reservations about ASEAN's policy of 'constructive engagement' with Myanmar. (IHT 23/24-07-94; FEER 28-07-94 p. 28)

Vietnam would be accepted as member of ASEAN at the annual Foreign Ministers Conference in Brunei, July 1995. (IHT 16-06-95)

\section{Relations with Vietnam}

Two-way trade between ASEAN members and Vietnam rose more than ten times to more than $\$ 1.6$ billion in 1992 from $\$ 163$ million in 1989 , the year Vietnam withdrew its troops from Cambodia. ASEAN thus raised its share of total Vietnamese trade to 32.4 percent in 1992, from 3.6 percent in 1989 . While still behind Taiwan and Hong Kong, ASEAN's share of foreign investment commitments in Vietnam more than doubled to 15.5 percent in the three years to December 1993. (IHT 03-08-94) 


\section{ASEAN Free Trade Area (AFTA)}

ASEAN economic ministers at their meeting at Chiang Mai in September 1994 approved changes in the AFTA-arrangement in order to expedite the free-trade area, by endorsing the reduction of tariffs to near zero five years ahead (10 years instead of 15 ) of the original target date of 2008 . Tariffs above $20 \%$ must be reduced to $0-5 \%$ by 2003 , and tariffs below $20 \%$ must fall to $0-5 \%$ by 2000 . Some goods would be subject to a 'fast-track' schedule under which tariffs are to be reduced to 0-5\% by 1998 .

The ministers also endorsed a broadening of the scope of AFTA by extending the number of goods covered by including unprocessed agricultural products. Each country would retain the right, however, to keep some sensitive agricultural products out of AFTA.

The ministers agreed that a list of excluded goods, originally subject to a review after eight years, would be formally phased out over five years beginning 1996. (IHT 24/25-09-94; FEER 06-10-94 p. 15))

\section{Attitude within APEC}

ASEAN economic ministers at their meeting in Chiang Mai in September 1994 distanced themselves from the recommendations of APEC's Eminent Persons Group. They were of the opinion that the EPG proposals for an "Apec Concord on Investment Principles and Apec Dispute Mediation Services" could lead to "excessive institutionalization". The ministers recommended that the EPG be disbanded, and agreed that each ASEAN member would act independently from each other within APEC. (IHT 24/25-09-94; FEER 06-10-94 p. 15)

\section{ASYLUM}

\section{East Timorese in US embassy}

Twenty-nine East Timorese in Jakarta entered the US embassy compound on 12 November 1994 and refused to leave in spite of Indonesian assurances that there would be no arrests or retaliation as a result of their action. The occupiers made a number of demands, including US intervention in the issue of East Timor and obtaining political asylum. The US president who was on a visit in Indonesia said that the US had 'no problem' with the occupation and that he felt 'comfortable' with the Indonesian assurance that no retribution would be exercised.

The Portuguese prime minister said his government was willing to offer asylum and the Indonesian state secretary said Indonesia had no objections to anyone seeking asylum in another country. (IHT 15-11-94; UN doc. E/CN.4/1995/117 of 03-02-95) The offer was accepted by the dissidents on 22 November 1994 who, however, preferred to speak of 'repatriation' so as not to imply recognition of the Indonesian title. (IHT 23-11-94; FEER 01-12-94 p. 16) 


\section{Asylum in Australia}

Hundreds of East Timorese, who were granted visitor visas to Australia by the Australian consulate at Bali, applied for asylum upon arrival. It was said that the Australian willingness to have the applications reviewed by the federal Refugee Review Tribunal might conflict with the Australian view that Indonesia should be regarded as the administrative authority in East Timor. (IHT 15/16-04-95)

\section{BORDERS, BORDER DISPUTES AND BORDER INCIDENTS}

(see also: Inter-state relations: general aspects, at p. 437; Joint development)

\section{Applicable principles on maritime boundaries}

It was reported that Indonesia and the Philippines had agreed on three principles in drawing up their maritime boundaries. These principles are: the applicability of the UN Convention on the Law of the Sea, the 'median line' principle, and the applicability of unspecified 'creative options'. (Indon. Times 28-07-94)

\section{China - Vietnam}

Having last met in Beijing in 1993 the two countries held a second round of talks in Hanoi in August 1994 on border issues and their overlapping claims in the South China Sea. (FEER 25-08-94 p. 13)

According to a joint communique issued on 22 November 1994 on the occasion of a visit by the Chinese president to Vietnam, China and Vietnam agreed not to escalate their territorial disputes nor resort to force and that they were willing to work for a peaceful settlement. It was also agreed to form an expert group to negotiate a settlement of their rival claims to the Spratly Islands. (IHT 23-11-94; FEER 01-12-94 p. 13)

\section{Gulf of Thailand delineation}

Thailand and Vietnam held talks early January 1995 on the delineation of their borders in the Gulf of Thailand where they have overlapping claims. (BP 13-12-94)

\section{US helicopter strayed into North Korean air space}

On 17 December 1994 a US helicopter "on a standard reconnaissance flight along the border" strayed into North Korean airspace and crashed about three miles north of the Demilitarized Zone. The Korean authorities said they shot down the helicopter, the US said it made an emergency landing. One of the two pilots was killed, the other was captured. (IHT 19 and 21-12-94) North Korea returned the body of the killed pilot on 22 December while the one who survived would be held until the completion of the investigation of the incident. (IHT 22, 23 and 29-12-94) On 28 December North Korea published a statement by the pilot to the effect that the incursion was a violation of international law. This was later followed by a written understanding between the US 
and DPRK deputy foreign ministers on the incident. Under the arrangement the US acknowledged that there was 'no legal basis' for the helicopter to have been in DPRK air space and expressed sincere regret for the incident, agreeing to contacts in an 'appropriate forum' designed to prevent such incidents in the future. This referred to a North Korean demand that the Military Armistice Commission be bypassed and to its preference for a new entity consisting solely of North Korean and US military officials. (see: Korean War at p. 461) On 30 December 1994 the pilot was released. (IHT 30-1294, 31-12-94/01-01-95)

\section{Opening of Sino-Indian border passes}

China and India concluded an agreement on 18 July 1994 for the opening of an ancient trade route through Shipkila pass on the border of Kinnaur District of the state of Himachel Pradesh. (BLD 1994 No.15)

The two countries later agreed to open other new passes along their Himalayan borders, including the Nathu La pass in Sikkim. [Indian rule over Sikkim has been disputed by China since India took over control in 1975, when a popular revolt led to the abdication of the Buddhist ruler. In December 1994 a left-leaning state government was elected, defeating a group widely regarded as closer to China.] (IHT 06-03-95)

Myanmarese intrusions into Thailand

(see also: Insurgents )

Myanmarese troops and members of an allied Karen guerilla faction crossed into Thailand and set fire to a Karen refugee camp in northwest Thailand on 25 April 1995. (IHT 27-04-95)

\section{Malaysia-Thailand boundary line demarcation}

It was announced on 26 May 1995 that the Malaysian government had almost completed the demarcation of the Thai-Malaysian boundary line, based on factors such as historical facts and maps. (NST 27-05-95)

\section{BROADCASTING}

\section{BBC broadcasting from Thailand}

Under an agreement between the Thai government and the BBC the latter would build a radio transmitter in central Thailand which would improve reception of the BBC world service from Beijing to Bombay. (FEER 28-07-94 p. 13)

\section{Voice of America broadcasting from Sri Lanka}

The Sri Lankan and US governments had resolved problems relating to the construction of a Voice of America relay station near Chilaw, on the country's western 
coast. The construction had been suspended following protests by villagers in the area. (FEER 16-02-95 p. 13)

\section{CAMBODIA}

\section{Khmer Rouge}

In early July 1994 the Cambodian parliament voted unanimously to outlaw the Khmer Rouge by making it illegal to be a member of the organization. (IHT 09/10-0794) The Khmer Rouge then proclaimed a "Provisional Government for National Solidarity and the National Salvation of Kampuchea" on 11 July 1994. It recognized King NORODOM SIHANOUK as "the true patriotic and honorable king of the Khmer nation". (IHT 12-07-94)

The Khmer Rouge appeared to have suffered a serious setback in February 1994 when government forces overran their northern base of Anlong Veng near the border with Thailand, but the base was recaptured two weeks later. In March 1994 the army seized Pailin, a gem-mining and timber centre where the Khmer Rouge had their headquarters. On 9 April 1994 the town was recaptured and in July the Khmer Rouge, having been formally outlawed by the Cambodian parliament, set up a 'provisional government' in an enclave near the border with Thailand.

On 26 July 1994 three tourists from Australia, France and Britain were abducted after a train hijacking, along with ten Cambodians and three ethnic Vietnamese. They were initially held in a Khmer Rouge village for a ransom of about $\$ 138,000$ worth of gold but on 15 August the Khmer Rouge said that the three men would be freed only when their governments publicly pledged not to provide military aid to the central government. Several government and military officials were offering their mediation to achieve the release of the hostages for various amounts of money. On 5 September 1994 the King called on the government to consider two conditions put forward by the Khmer Rouge for securing the release of the hostages and easing the security risks for foreigners in Cambodia. The first was the repeal of the law which declared the Khmer Rouge outlawed. The second was the reopening of the Khmer Rouge office in Phnom Penh. In October rumors started to circulate according to which the hostages had been killed in September. These rumors were later confirmed by the government. (IHT $13 / 14-08,18-08,23-08,24-08,25-08,06-09,28-10-94$ )

\section{Coup d'etat}

It was reported that there was a coup attempt (infra, p. 432) led by a former deputy prime minister, Prince NORODOM CHAKRAPONG and a general. The two had earlier mounted an abortive secessionist movement in June 1993. (see 3 AsYIL 357) The prince was, as a result, sent into exile in Malaysia on 3 July 1994. In view of a forthcoming visit to Malaysia by the Cambodian co-premiers the Cambodian government requested that the Prince depart from Malaysia before the visit. The Prince left Malaysia for Thailand on 4 August and a few days later he was granted asylum in France. (FEER 14-07-94 p. 14-16; 28-07-94 p. 13; 18-08-94 p. 13) 


\section{Foreign assistance for retraining of the Cambodian army}

It was reported that a consensus had emerged in ASEAN on the need of foreign military assistance to Cambodia. However, supply of arms and combat equipment might be opposed by China and Thailand, who would argue that it would inflame the situation, and that the factions in Cambodia should settle their political differences by negotiations. (IHT 28-07-94)

Almost simultaneously it was reported that the US was in fact already sending military trainers, money and (non-lethal) equipment to Cambodia. The supply of arms and ammunition was being considered but a final decision would have to await consultations with other countries involved in efforts to rebuild Cambodia. The Cambodian side openly emphasized the need for arms and ammunition. (IHT 29-07-94)

\section{CHEMICALS AND CHEMICAL WEAPONS}

(see: Nuclear capability, at p. 471)

\section{CIVIL WAR}

\section{Cease-fire agreement in Tajikistan}

As a result of consultations between the Tajik government and the Tajik opposition under UN auspices in Teheran, agreement was reached on 17 September 1994 on "a temporary cease-fire and the cessation of other hostile acts on the Tajik-Afghan border and within the country for the duration of the talks". In order to ensure the effective implementation of the agreement a joint commission was to be established as the main element of a monitoring mechanism. The two sides reaffirmed their commitment to resolve the conflict through political dialogue and agreed in a joint communique to hold a next round of inter-Tajik talks in Islamabad in the middle of October 1994. (S/1$994 / 1102$ and $S / 1994 / 1080$, with text of agreement and joint communique)

However, on 3 January 1995 the ministry of foreign affairs referred to "continuing attempts by detachments of the Tajik opposition to cross the border [from Afghanistan] illegally". It accused the opposition of "seeking to give world opinion a false picture of the activities of Russian border guards". It stated that "the activities of Russian border guards are restricted to the performance of tasks necessary for the safeguarding of the Tajik-Afghan border. ... The legal basis for the presence of Russian border troops in Tajikistan is the Agreement between the Russian Federation and the Republic of Tajikistan on the Legal Status of the Border Troops of the Russian Federation Situated in the Territory of the Republic of Tajikistan" which was signed in Moscow on 25 May 1993. (UN doc. S/1995/27 of 12-01-95) Besides, a border-security treaty was signed on 17 August 1994 between Russia and Tajikistan, Uzbekistan and Turkmenistan, formalizing the presence of Russian troops in all three states, thereby angering Pakistan, Iran and Afghanistan. (FEER 15-09-94 p. 17)

During a visit of the Tajik president to Iran in July 1995 negotiations were held between the president and Tajik opposition groups, resulting in a declaration. In it the 
parties agreed on joint efforts to implement the understandings reached during the interTajik peace talks (above). The parties also agreed to establish a Consultative Assembly of Tajik Peoples and to meet for a fifth round of inter-Tajik peace talks in August 1995. (UN doc. S/1995/639)

\section{Afghanistan}

(see also: 4 AsYIL 422)

A new faction in the civil war, the Taliban (Taleban) movement, aiming at the establishment of a strict Islamic state, was formed in September 1994 under the leadership of Mullah MOHAMMED OMAR. The movement was recruited from young Afghan refugees who had attended religious schools in Pakistan, most of them belonging to the Pashtun sub-tribe of Durrani. Although Pakistan publicly denied involvement, the movement seemed to be favorably viewed by Pakistan and Saudi Arabia.

In November the Taleban conquered the city of Kandahar, on 11 February 1995 it conquered Maidan Shahr, a major stronghold of the Islamic Party of GULBUDDIN HEKMATYAR (whose followers are mostly Pashtun of the Ghilzai sub-tribe). The latter's headquarters at Charasyab, 15 kilometres south of Kabul, was taken on 14 February (but lost again in March). The eastern province of Logar was equally abandoned by the Islamic Party. The conquered territories were mainly Pashtun areas bordering Pakistan. (IHT 06, 11/12, 15, 16, 21-02-95, 01 and 22-03-95; FEER 18-05-95 p. 24) It was reported in February that the Taleban had taken control of more than 40 percent of Afghanistan, in 9 or 10 of the 40 provinces. (IHT 17-02, 22-03-95) On 8 March 1995 the Taliban forces were reported to have started clashing with government troops. (IHT 09-03-95) In May 1995 government forces made several advances against the Taleban. They had taken over three regions in northern Nimroze Province and were surrounding its capital. They also had defeated Taleban forces in Farah Province in western Afghanistan and had forced the latter to withdraw to Nimroze and Helmand Province. (IHT 15-05-95) On 21 May 1995 government forces took a strategic position near Kabul, striking a new blow to the Taleban movement (IHT 22-05-95). These successes were repeated the following days. (IHT 23-05-95)

Assisted by the good offices of the UN Special Mission to Afghanistan the Afghan factions reached agreement in December 1994 on the composition of an interim mechanism of government and on the transfer of power by the president to a multiparty governing council on 20 February 1995 . However, the advance of the Taleban forces and their refusal to participate in the arrangement disrupted the plan. (IHT 17-02 and 18/19-02-95, UN doc. A/50/737 of 08-11-95) First the transfer of power was postponed to 21 March, but on 16 March the president said that he would be "waiting for a reliable mechanism" before transferring power.

In the first half of 1995 the country was effectively controlled by three major military powers: first, the president and his commander, AHMAD SHAH MASSOUD, together with their ally, Governor ISMAEL KHAN of Herat province; second, General RASHID Dostam (Dostum), head of the National Islamic Movement of Afghanistan (NIMA), mainly in the northern part of the country (see 2 AsYIL 283); third, the Taleban in the south and south-eastern provinces. (UN doc. A/50/737 of 08-11-95) 


\section{COMPENSATION}

(see also: Inter-state relations: general aspects, at p. 434)

\section{Cambodia/Vietnam - US}

The two countries concluded agreements with the US, on 6 October 1994 and 25 January 1995 respectively, concerning the settlement of mutual property claims arising from nationalization, expropriation or taking of, or other measures directed against, properties, rights and interests of the other side. Under the agreement Cambodia and Vietnam were to pay $\$ 6$ million and $\$ 208,510,481$ respectively, to the US in full and final settlement of the claims. The amounts were to be deducted from the assets of the two states that were blocked in the US and would be unblocked. (34 ILM (1995) 600 and 686)

\section{DEBTS}

\section{China's foreign debt}

At the end of 1994 China's foreign debt reached $\$ 100$ billion, about fifty percent in dollars and 25 percent in yen. The debt-service ratio was below the 20 percent of annual export earnings. (IHT 18-01-95) The dollar-value of the yen-denominated debt had risen considerably as a result of the surging yen: from $\$ 10$ billion at issue in 1979 to $\$ 16.8$ billion.

On the occasion of the Japanese prime minister's visit to China in early May 1995 the Chinese prime minister asked Japan to ease China's debt-repayment schedule. China had repeatedly asked either for new loans to help repay the debt or a softening of terms. But Japan always replied that Japan could not make an exception for China. (IHT 04-05-95; FEER 23-03-95 p. 63)

\section{Rescheduling of Russian debts}

It was reported that China had agreed to reschedule a $\$ 306$ million debt incurred by the Soviet Union in 1991. (IHT 28-06-95)

\section{Auction of Indian debts}

Russia announced its intention to auction off part of the Rs.360 billion ( $\$ 11.4$ billion) owed by India to Russia. The amount sold to bidders in any year would be about half India's annual repayments of Rs. 30 billion. It was said that Russia promised India to ensure that the rupees would remain in the hands of Russian importers. (FEER 14-07-94 p. 18) 


\section{Debt management by poor states}

On the initiative of Indonesia a meeting of poor indebted states was held in August 1994. According to World Bank figures, the world's 33 severely indebted low-income countries owed a total of $\$ 179$ billion at the end of 1992 . Among these three were Asian countries: Myanmar, Bhutan and Laos. According to the World Bank $61 \%$ of the $\$ 179$ billion owed by severely indebted countries was in the form of bilateral loans, $24 \%$ was multilateral assistance and $15 \%$ was owed to private lenders.

A Non-alignment Movement (NAM) ad hoc advisory group of debt experts had concluded that what was required was a substantial cut in total stock debt instead of further rescheduling. The report by the Group's chairman GAMANI COREA proposed that the debts of $55-60$ countries should be cut by roughly $70 \%$, corresponding to the value of the countries' debt instruments in secondary financial markets. (FEER 15-0994 p. 72)

\section{Vietnam's debts to Russia}

Among the legacy of the Soviet-Vietnamese alliance was a debt of 10 billion roubles for which no satisfactory solution has yet been found. The problems were how to include the value of the rent for the naval facilities at Cam Ranh Bay and how to calculate the current value of the debt. As to the former, Russia offered to pay $\$ 60$ million a year, to be deducted from Vietnam's outstanding debt. Vietnam refused as it did not want the debt and the naval base linked. With regard to the debt Russia would like Vietnam to pay back the debt at $\$ 1$ to the rouble, although the rouble had sunk to more than 4,000 roubles to $\$ 1$. (FEER $16-03-95$ p. 22)

\section{DEVELOPMENT AID}

(see: Economic cooperation and assistance)

\section{DIPLOMATIC AND CONSULAR INVIOLABILITY}

\section{Shooting of foreign diplomat}

An Iranian diplomat and his nine-year old son were among nine people killed in a shoot-out in Beijing on 20 September 1994 after an armed Chinese soldier ran amok. (FEER 29-09-94 p. 13)

\section{Armed attack on US consular personnel}

Masked gunmen ambushed a van of the US consulate in Karachi on 8 March 1995, killing two consulate staff members and wounding a third with automatic weapons. No group had yet taken responsibility. It was reported that policemen present at the scene did not pursue the attackers for fear of being killed. The US FBI sent agents to Pakistan and Karachi police sources revealed that the FBI would head the investigation. 
(IHT 09-03-95) On 17 April 1995 police in Karachi shot a man considered a suspect in the killing. (IHT 18-04-95)

\section{DIPLOMATIC PROTECTION}

(see also: Aliens; Migrant workers)

\section{Philippine intervention on behalf of Philippine national}

A Filipino woman had been sentenced to death by the Singapore court in April 1994 for the murder in 1991 of another Filipino woman and a 4-year old Singaporean boy. The death penalty is mandatory for murder in Singapore. The Philippine government appealed for a delay of the execution, claiming that new evidence had surfaced, and asking for another review of the case. This appeal was rejected by the Singapore government after it had investigated the allegedly new evidence and had found it untrue. The Singaporean government said the woman had received a fair trial. She was executed on 17 March. (IHT 14, 16, 17 and 18/19-03-95)

The Philippine consul-general in Singapore was quoted as saying that the woman concerned rejected advice that she refrain from signing any confession and instead insisted that she had committed the murders. This statement was in essence repeated in the consul-general's testimony before the Philippine Senate, and the Philippine ambassador to Singapore too said she never heard the woman proclaim her innocence. (IHT 20 and 24-03-95)

The hanging sparked nation-wide anger in the Philippines, leading to the recall of the Philippine ambassador 'indefinitely' on 22 March 1995 and the appointment of a chargé d'affaires. This was reciprocated by the recall of the ambassador of Singapore for consultations. There were street protests, calls to boycott Singaporean companies and the burning of the Singaporean flag in the town of Davao. A diplomatic protest by Singapore and a demand that the flag-burners be prosecuted and similar acts be prevented were rejected with a reference to 'freedom of expression'. As a result of the strained relations, a visit by the prime minister of Singapore scheduled for April was postponed, a scheduled visit to Singapore of the Philippine chief of the armed forces was cancelled, and Philippine-Singapore joint naval exercises scheduled for July 1995 were indefinitely postponed.

A military transport plane was sent to Singapore to repatriate those among the 60,200 Filipinos working in Singapore who wanted to go home. Eighty-four maids took advantage of the offer.

The Philippine president established a special commission headed by a Supreme Court judge ("Gancayco Commission") to investigate the case and warned that, if the commission would conclude that a miscarriage of justice had taken place, he would not hesitate to cut off diplomatic relations. However, he also said that if the inquiry established the woman's guilt, Filipinos must have the grace to acknowledge before the world that their outrage had been misplaced. (IHT 23-03, 31-03-95)

A government medical examiner carried out an autopsy on the body of the victim and suggested that she might not have been killed by strangulation as the Singapore court had ruled. (IHT 31-03-95) The presidential commission finished its inquiry on 6 
April 1995. It concluded that the medical examiner's finding tended to show that the convicted woman was "mistakenly blamed and hanged", and recommended reopening the double-murder case. The Singapore government reacted to the report by stating that the Commission findings were based on uncorroborated or hearsay testimonies but had ignored other crucial evidence.

The Philippine president thereupon proposed on 1 April 1995 an autopsy by a third party to resolve the conflicting autopsy reports by Philippine and Singaporean experts. The proposal was accepted by Singapore, suggesting eight forensic experts and three internationally recognized forensic research institutes. However, the two parties agreed to try to have the Singapore and Philippino forensic scientists settle their conflict of opinion before having recourse to third-party adjudication. (IHT 3, 7, 10, 11, 12 and 17-04-95) The joint autopsy which took place on 19 April failed to resolve the differences. The Singaporean experts stuck by their findings which were endorsed by US forensic experts who attended the new examination. (IHT 20-04-95) The two parties then agreed to ask the American FBI to conduct an autopsy. Singapore agreed to reopen the case if the results confirmed the findings of the Filipino experts, but if they confirmed the Singaporean findings, the Philippines would no longer pursue the case. (IHT 02-05-95; FEER 01-06-95 p. 38)

\section{DIPLOMATIC AND CONSULAR RELATIONS \\ (see also: Inter-state relations: general aspects)}

\section{Mutual expulsion of Indian and Pakistani diplomats}

In July 1994 an Indian diplomat was detained "while receiving highly sensitive documents from a Pakistani agent" and later expelled from Pakistan. While protesting against the "unlawful detention and brutal torturing" India reciprocated by expelling two Pakistani diplomats from India. (IHT 13-07-94)

Late August an Indian envoy was accused of spying in Pakistan and was expelled. This was again reciprocated by the expulsion of a Pakistani diplomat. (IHT 31-08-94)

After another round of expulsions of diplomats Pakistan on 26 December 1994 ordered India to close its consulate-general in Karachi, accusing it of 'sponsoring terrorism' in the city [involving members of the Muhajir National Movement of Muslims who migrated from India to Pakistan in 1947]. The Pakistani government said it had "evidence of Indian involvement in the planning, instigation and execution of acts of terrorism and violence in Karachi and of the propagation of disaffection and propaganda against the unity, territorial integrity and sovereignty of Pakistan". The Pakistani foreign minister said the police had arrested 14 people who claimed to have been recruited by India's secret service to create trouble in Karachi. (IHT 27-12-94) The consulate was closed on 4 January 1995. (IHT 05-01-95) 


\section{China - Latvia}

China agreed to re-open its embassy in Latvia after Latvia agreed to close the Taiwanese consulate which was opened in 1992. Sino-Latvian relations were never officially broken off. (FEER 11-08-94 p. 13)

\section{Argentine - Iranian relations}

The Argentine minister for foreign Affairs said that even if Iranian diplomats were found to be involved in a bomb attack in Buenos Aires (see (Non-)Interference) Argentina would not sever diplomatic relations with Iran. (IHT 10-08-94)

\section{Evacuation of South Korean diplomats from Algeria}

South Korea ordered its diplomats to leave Algeria because of the violent situation in that country. (IHT 17-11-94)

\section{Malaysia - Burkina Faso}

It was announced on 4 January 1995 that the two countries had established diplomatic relations. (NST 05-01-95)

\section{North Korea - Poland}

In February 1995 North Korea ordered the Polish contingent in the Neutral Nations Supervisory Commission to leave the Panmunjon border area. (see: Korean War at p. 461) Poland responded by recalling its ambassador to North Korea and demanding the downsizing of the North Korean mission in Warsaw to half. North Korea thereupon recalled its ambassador on 5 April 1995. (IHT 06-04-95)

China - US

China announced on 17 June 1995 that it was recalling its ambassador in the US "in view of the current state of Chinese-US relations", apparently referring to the visit by the Taiwanese president to the US. (IHT 17/18-06-95)

\section{DISARMAMENT AND ARMS CONTROL}

\section{Chinese stand on US ballistic missile defense system}

China warned on 17 February 1995 that the US would "increase the danger of nuclear war" if it proceeded with a plan to develop an advanced ballistic missile defense system in Asia. This opposition stems from fears that it could block China's small force of nuclear-tipped strategic missiles by the potential for a first strike without fear of retaliation. (IHT 18/19-02-95) 
DISSIDENTS

(see also: Asylum)

\section{Dalai Lama visit to Japan}

China criticized Japan for permitting the Dalai Lama to visit Japan. The Dalai Lama was invited by the Kurozumi Kyo, a religious group. (IHT 31-03-95)

\section{DIVIDED STATES: CHINA}

(see also: Arms sales and supplies; Diplomatic and consular relations; Inter-state relations: general aspects, at p. 442)

\section{Taipei white paper}

The Mainland Affairs Council in Taipei on 5 July 1994 released a policy paper on "Relations across the Taiwan Strait". In it the Taiwanese side stated that it "would no longer compete with Beijing for the right to represent China in the international arena". The document, inter alia, called on Beijing to recognize the political fact of China being a divided country under two separate governments. While affirming the principle of a single China including Taiwan, Taiwan should be acknowledged as a separate 'political entity'. Neither government should claim overall sovereignty since each had jurisdiction over only part of China. Prior to unification these two parts of China should have the right to participate alongside each other in the international community. (IHT 07-07-94; FEER 21-07-94 p. 20, 04-08-94 p. 30)

\section{New intra-Chinese talks}

(see 3 AsYIL 366)

On the occasion of a visit of the Chinese president to Indonesia the President's spokesman said on 18 November 1994 that China was willing to hold high-level reunification talks with Taiwan as long as they take place on an intra-Chinese basis. (IHT 19/20-11-94)

In his Lunar New Year speech the Chinese president said that the Taiwanese president was welcome to visit the mainland "in an appropriate capacity" and that he himself would like to visit Taiwan. He also called for a formal end to hostilities. There was an affirmation of respect for the rights of the Taiwanese people, but he also made clear his opposition to Taiwanese independence. (FEER 16-02-95 p. 14)

On 28 February 1995 the Chinese president called for a face-to-face meeting between leaders of the two sides (02-03-95) and on 9 April 1995 Taiwan officials said they expected a positive response from China over an offer to improve contacts and cooperation made by the Taiwan president. (IHT 10-04-95)

Negotiators from both sides met again in May 1995 in Taiwan in order to lay the groundwork for a second round of the highest-level meetings so far, projected for midJuly. However, on 16 June China decided to postpone such a meeting, and also preparatory talks scheduled for the end of June. (IHT 25-05 and 17/18-06-95) 


\section{Accord on repatriation of hijackers and illegal immigrants}

Negotiators for the two sides reached agreement on both subjects on 7 August 1994. The breakthrough came when Beijing conceded Taipei's demand that it had the right to exclude some hijackers from repatriation if it determined that they had valid political or religious motives. Previously China had refused to acknowledge the jurisdiction of Taiwanese courts to make such a decision.

On the repatriation of illegal immigrants it was agreed that the Chinese authorities must arrange to take them back within 20 days. On failing to respond, the Taiwanese authorities would summarily ship the offenders back to a Chinese port. (IHT 08-08-94)

The agreement, which also covered a settlement on fishery disputes and a duty to notify each other of deaths or robberies involving visitors, was signed on 8 August 1994. (IHT 09-08-94)

Renewed talks between two top members of the quasi-official bodies of the mainland and Taiwan were held on 21-27 January 1995. On 22 January it was reported that agreement was reached on the return of hijackers, but the talks broke down over fishing disputes: the Beijing government refused to have such disputes mediated by whichever side was closest to the dispute site, because this would imply the existence of 'Taiwanese waters'. (IHT 14/15 and 23-01-95; FEER 16-02-95 p. 15)

\section{Taiwan's Hong Kong-Macao Relations Bill}

In view of Taiwan's bar to direct links with the mainland, Hong Kong's reversion to Chinese rule would make travelling or trading through Hong Kong illegal for Taiwanese. As a solution Taiwan's Hong Kong-Macao Relations Bill would grant the two territories special third-party status, setting them apart from the rest of China. (FEER 01-09-94 p. 22) (see also infra on 'offshore shipping centres')

\section{Taiwan application for UN membership}

The General (steering) Committee of the UN General Assembly for a second time rejected a Taiwanese application for UN membership. The Taiwan item was originally introduced in 1993 by seven Central-American states: Belize, Costa Rica, El Salvador, Guatemala, Honduras, Nicaragua and Panama. (IHT 23-09-94; FEER 06-10-94 p. 29)

In June 1995 Taiwan offered to set up a billion-dollar fund for developing countries on condition of admission as member of the UN. (IHT 28-06-95)

\section{Conflict over attendance of officials at Asian Games}

A problem arose when the Olympic Council of Asia invited the president of Taiwan to attend the Asian Games to be held in early October 1994 at Hiroshima, Japan. After Chinese protests the invitation was withdrawn on the grounds that no political figures would be invited. Instead the Taiwanese vice-prime minister as part of a mission representing Taipei's bid to hold the 2002 Asian Games would come to the Games. Although China kept criticizing Japan for allowing the attendance of a high- 
level Taiwanese politician and cancelled the attendance of a Chinese State Councillor it did not carry out its threat to boycott the Games. (IHT 28-09-94, 01/02-10-94)

\section{Erroneous shelling from coastal island}

Taiwan forces at Xiaojinmen Island fired a dozen or more artillery shells into a village on the southern coast of mainland China on 14 November 1994. A statement from the Taiwanese side failed to fully explain how the incident occurred, but deep regret was expressed and a promise was made for the compensation of the injured. (IHT 16-11-94; FEER 24-11-94 p. 13)

\section{Relaxation of Taiwanese bans by way of 'offshore shipping centre'}

On 1 March 1995 it was announced that Taiwan would lift more curbs on contacts by permitting mainland officials to visit the island on a case-by-case basis. It would also raise the status of the Straits Exchange Foundation which represents Taiwan in intraChinese talks, and allow Taiwan banks to open representative offices on the mainland.

The government in Taiwan granted approval to a plan which would allow foreignregistered ships (although Taiwanese-owned) to carry cargoes between the mainland and the port of Kaohsiung for transshipment to other countries or from other countries. Kaohsiung would be designated 'offshore shipping centre' for these purposes. The offshore transshipment center plan was confirmed and put into force on 4 May 1995. (IHT 7/8-01 and 05-05-95; FEER 02-02-95 p. 29)

\section{Joint oil exploration}

It was reported that Chinese officials would visit Taipei in August 1995 to attend a seminar on joint oil exploration. The officials had held two previous similar meetings in Singapore. (IHT 24-04-95)

\section{Taiwan attitude towards double nationality}

Although under the applicable law in Taiwan Chinese nationals are not barred from simultaneously holding another country's nationality, the Election and Recall Law was amended so that dual citizens are not required to renounce their foreign citizenship before taking the oath of public office. A general law dating from 1929 already barred Chinese government officials from holding foreign citizenship. (FEER 18-05-95 p. 28)

\section{Feasibility of Hong Kong formula for Taiwan}

The question whether the Hong Kong formula of 'One country, two systems' could be used for Taiwan, was answered in the negative by the chairman of the [Taiwan] Mainland Affairs Council. "Hong Kong's situation is totally different from Taiwan. Hong Kong is a colony - period. Taiwan is the Republic of China. The Republic of China is a sovereign state." He said that under the Hong Kong formula the government 
in Beijing would have ultimate control, and despite the safeguards being built in, that government would prevail in any dispute. (IHT 19-06-95)

\section{Mainland-Taiwan relations after Hong Kong's return to Chinese rule}

China announced a 7-point plan for relations between Taiwan and Hong Kong after the latter's return to Chinese rule in 1997. The plan indicates that little will change. It contains, inter alia, the following: (1) Taiwanese capital and people will be welcome and their rights will be protected in accordance with Hong Kong law. Entry and exit will be governed by Hong Kong law; (2) Air and sea traffic will continue unfettered, "based on the principle of mutual benefit"; (3) Non-governmental groups in Hong Kong and Taiwan may continue contacts "on the basis of non-subordination, non-interference and mutual respect"; (4) Taiwanese organizations and staff will be able to stay on after 1997, provided they do not "engage in activities which would damage Hong Kong's stability and prosperity”. (IHT 24/25-06-95)

\section{Equation of persons from Hong Kong and Taiwan with Chinese nationals}

The Beijing municipal education department ordered the Beijing International School to reject dependents of Taiwanese and Hong Kong executives based in China as pupils. These children were claimed to be Chinese nationals and as such barred from attending foreign-backed schools. (FEER 29-06-95 p. 26)

DIVIDED STATES: KOREA

(see also: Emergency aid)

\section{Summit meeting}

As a sequel of the CARTER-KIM IL SUNG-talks a first North-South summit meeting was set for 25-27 July 1994 in Pyongyang. It was intended for the easing of tensions over North Korea's refusal to allow full inspections of its nuclear facilities. (IHT 2/307-94) The meeting was, however, postponed indefinitely because of the death of the North Korean President on 8 July 1994. (IHT 11 and 12-07-94)

In January 1995 South Korea offered to re-open government-level talks, but these were rejected by the North. (IHT 28/29-01-95)

\section{Ban on joining in mourning in North Korea}

On 14 July 1994 North Korea invited South Koreans to the North to take part in mourning rites but this was rejected by South Korea which repeated its stand that the government alone could handle contacts with North Korea. (IHT 16/17-07-94) 


\section{German-style reunification}

In apparent contradiction to earlier expressions of South Korean policy the Deputy Premier and Unification Minister confirmed on 8 August 1994 that South Korea would immediately accept a German-style formula for reunification. (IHT 09-08-94)

\section{Lift of ban on direct trade and investment}

South Korea on 7 November 1994 lifted a ban on direct trade with and investment in North Korea. The South Korean president said that the two countries should adopt a framework agreement to accelerate trade and investment and that the South would begin the process by allowing business people to visit the North. He also said that South Korea would back an application by North Korea to join APEC. South Korean conglomerates said that North Korea had earlier invited them to discuss investment matters. (IHT 08-11-94) On 10 November, however, North Korea rejected the South Korean move. (IHT 11-11-94)

It was reported in December 1994 that the South Korean Sangyong group had agreed with North Korea to produce and export cement, and to take part in projects to build free-trade zones in Rajin and Sonbong in North Korea. (IHT 19-12-94) (cf. Tumen River development area, infra p. 456)

The first investment approval by South Korea was issued in May 1995, for the production of garments and other light-industry goods. (IHT 18-05-95)

\section{Cancelation of South Korean-US manoeuvres}

For the second year in succession the two countries agreed to cancel joint military 'Team Spirit' manoeuvres, in order to placate North Korea which characterizes these exercises as rehearsals for a nuclear assault. (IHT 27-02-95)

\section{Intrusion of territorial waters}

A South Korean trawler was fired on and seized by a North Korean patrol boat after it entered the North Korean territorial waters on its way back to South Korea from China where it had been held a few days for fishing illegally in Chinese waters. A South Korean defence ministry spokesman said that according to preliminary investigation a malfunction of the ship's compass might be to blame for the incident.

South Korea had accused North Korea of having seized more than 3,500 South Korean fishermen since the war and of still holding more than 400. (IHT 31-05, 01-06-95)

\section{EAST ASIA ECONOMIC CAUCUS}

(see: 1 AsYIL 289, 2 AsYIL 305, 4 AsYIL 432)

\section{State of affairs}

Originally being a Malaysian initiative, the EAEC proposal had been pushed by 
ASEAN countries as a whole since their 1992 summit in Singapore.

During the ASEAN Ministerial Meeting at Bangkok in July 1994 Japan, China and South Korea had not yet decided to participate in the projected Caucus although China supported the idea right from the beginning. Nine of the eleven prospective members met to discuss the plan. Nobody explicitly disagreed with the idea of having a caucus, and there was agreement to continue developing the concept, and for the nine foreign ministers to meet informally for discussions. (IHT 26-07-94; FEER 15-09-94 p. 21)

In August 1994 the Japanese prime minister said during a visit to Malaysia that it was necessary to convince the US and other countries concerned that the EAEC would be an open trading system (Star 28-08 and 30-08-94), in September he said that Japan would require some time to convince its friends of the EAEC's objectives (NST 03-0994) and in December 1994 it was reported that the Keidanren (Japan Federation of Economic Organizations) was considering supporting the idea. (IHT 08-12-94)

\section{ECONOMIC COOPERATION AND ASSISTANCE}

(see also: Aliens)

\section{Development aid for the Philippines}

Donor governments meeting in Paris under the auspices of the World Bank pledged $\$ 5.6$ billion in official development assistance to the Philippines through the end of 1995. (FEER 04-08-94 p. 63)

\section{US development aid to Asia}

In fiscal 1995 the entire Asian region from Afghanistan to Indonesia was budgeted to receive $\$ 526$ million in economic assistance, $3.4 \%$ less than in fiscal 1994 . With food aid and Peace Corps volunteers excluded, this left a total of $\$ 316$ million for the region which contains more than half the world's poor.

For the fiscal year starting in October 1995 the US allocated \$282 million for development aid to East Asia and the Pacific. This was 2.65 percent of the $\$ 10.5$ billion US foreign aid budget. The Assistant Secretary of State for the region said this was a fitting proportion "given the dynamic economies of the region".

The US provides virtually no aid to countries like Thailand and Malaysia on the assumption that they have graduated beyond assistance. By contrast, such countries still receive considerable Japanese aid in the form of concessional loans as they are as it were in Japan's backyard so that the aid serves as a form of insurance. (FEER 18-0894 p. 18; IHT 16-03-95)

\section{Japan - Vietnam}

On the occasion of a the first visit by a Japanese prime minister to Vietnam in August 1994 the two countries signed five agreements on aid worth more than $\$ 73$ million and an agreement allowing Japanese peace corps workers to teach in Vietnam. 
Japan is the largest aid donor and trading partner. Aid and loans were resumed in 1992 after a 14-year suspension following the Vietnamese intervention in Cambodia. (IHT 27/28-08-94)

\section{Cooperation between Malaysia and Balkan states}

Malaysia, Bosnia-Herzegovina and Croatia agreed to work together towards the development and reconstruction of the war-torn Balkan states. Trade agreements with both countries were signed on 26 October 1994; two Malaysians were invited to sit on the governing board of the Bosnian agency for reconstruction and development; Malaysia would, inter alia, offer training in foreign relations and economy and management courses under the Malaysian Technical Co-operation Programme. (Star 2710-94)

\section{Multilateral aid to Vietnam}

At a meeting of about 30 countries and international organizations sponsored by the World Bank Vietnam was promised \$2 billion in new grants and loans for 1995. These pledges came in addition to $\$ 1.8$ billion promised in 1993 . The aid was promised by Japan, South Korea, Australia, Canada, Singapore and ten Western European countries. The US attended as an observer but made no financial commitment. (IHT 17-11-94)

\section{Japan - Myanmar}

Japan decided to resume official development assistance to Myanmar. It would probably offer 1-2 billion yen in grants annually from 1995 for humanitarian purposes.

Japan was Myanmar's largest donor when it cut off official aid in 1988 after the takeover of the government by the military. (FEER 17-11-94 p. 13)

\section{Japan - China}

Japan in December 1994 pledged to lend 580 billion yen to China from fiscal 1996 to 1998. That would make China the biggest recipient of Japanese development loans, ahead of Indonesia. (FEER 12-01-95 p. 13) The loan is part of a six-year aid programme. China is the only country that gets multi-year aid from Japan rather than aid for specific projects. The formula was adopted after the Peace and Friendship Treaty of 1978.

In 1992 Japan adopted an Official Development Aid charter (see 4 AsYIL 560) which directs reviewing the aid towards countries that cause concern in four areas: human rights, the environment, arms exports and the development of weapons of mass destruction. It was said that this requirement was adopted under the pressure of the US. Although China might not meet the tests Japan did not draw any consequence regarding the aid. (FEER 26-01-95 p. 25)

In May 1995 it was reported that Japan would cut its aid to China as a gesture of displeasure with the Chinese nuclear test conducted on 15 May. (FEER 01-06-95 p. 13) 


\section{Sino-US energy agreements}

While the two countries entered last-ditch talks to avert a trade war (see: International trade) they prepared for the signing of energy deals worth up to $\$ 8$ billion. (IHT 13-02-95)

\section{Central Asian Development bank}

Kazakhstan, Uzbekistan and Kyrgyzstan signed a series of agreements on political and economic cooperation, including the formation of a Central Asian development bank. (IHT 13-02-95)

\section{South Korea - Vietnam}

South Korea would sign an agreement on 22 March 1995 to lend $\$ 50$ million to Vietnam, the first South Korean governmental loan to that country. (IHT 21-03-95)

\section{South Korea applies for OECD membership}

The Republic of Korea on 29 March 1995 formally applied to join the Organisation for Economic Cooperation and Development. South Korea would have to reaffirm its commitment to the free market during the application procedure. (IHT 30-03-95)

\section{Japanese loans to Iran}

Japan announced it would delay the disbursement of a 45 billion yen project loan to Iran following a US imposition of a trade embargo. There would, however, be no formal suspension of economic relations. Iran supplies $9.7 \%$ of Japan's oil needs. (FEER 11-05-95 p. 13)

\section{Japan's position as aid donor}

Japan was the world's largest aid donor for the fourth straight year in the calendar year 1994. The amount granted by way of development aid was $\$ 13.24$ billion. The target of foreign aid over the five years to 1997 was $\$ 70$ billion. (IHT 30-06-95)

\section{EMERGENCY AID}

\section{Food shortage in North Korea}

North Korea asked Japan for emergency supplies of rice. In recent years North Korea has been increasingly open in admitting that it does not produce sufficient rice to feed its population. South Korean sources said that rice production totalled about 1.5 million tons in 1994, about 40 percent below subsistence levels. Japanese officials initially said it would be 'difficult' to provide rice to North Korea until the two coun- 
tries normalize their relations. Japan itself was currently a rice importer. Later there were indications that Japan might help by sending surplus rice. (IHT 27/28 and 29-0595) It would be prepared to give at least 300,000 tons, provided that South Korea would not object.

The latter already expressed willingness to help. A private South Korean shipping company said on 19 June 1995 that it had prepared vessels under a verbal agreement with the government to ship 50,000 tons of rice to North Korea. An agreement between North and South Korea on the supply of 150,000 tons of rice was signed on 21 June. The rice was expected to be provided without Republic of Korea labels. It was the first time that North Korea accepted rice from South Korea. (IHT 20, 21 and 22-06-95)

After this North-South transaction had taken place Japan decided to also provide rice to North Korea, but it was reported that the DPRK-Japanese talks stalled. One reason, among others, was Japan's request that North Korea promise not to sell the rice abroad or use it for the military. (IHT 23, 26 and 29-06-95)

On 30 June 1995 South Korea announced that it was suspending the rice deliveries because a South Korean ship had been forced to raise a North Korean flag when in port. South Korea demanded a formal apology. (IHT 30-06-95)

ENVIRONMENT POLLUTION AND PROTECTION

(see also: Inter-state relations: general aspects, at p. 437)

\section{Cases of transboundary pollution}

Forest fires in Indonesia that started in August 1994 caused smog to descend over Singapore and much of Malaysia. Indonesia and Singapore agreed on 29 September 1994 to coordinate action against future forest fires, and officials from Malaysia and Singapore were to meet in early October to discuss the problem.

Other transborder pollution problems occurred also elsewhere in Asia. Japan was being increasingly affected by acid rain caused by sulphur and nitrogen fumes from burning coal in China, and Vietnam was concerned that Thailand will draw excessive amounts of water from the Mekong River in the dry season, thus increasing intrusion of salt water from the sea into the Mekong delta region of Southern Vietnam. (IHT 3009-94)

\section{Indonesia-Malaysia biodiversity park}

The two countries on 7 October 1994 launched a transfrontier nature reserve: the Lanjak-Entimau/Bentuang-Karimun Biodiversity Conservation Area, comprising the Lanjak-Entimau Wildlife Sanctuary in Sarawak and the Bentuang-Karimun National Park in West Kalimantan. The project is possibly the largest tract of tropical rainforest in the world dedicated to total protection and biodiversity conservation, and is sponsored by the International Tropical Timber Organisation (ITTO). (Star 28-10-94) 


\section{Global warming}

A report entitled "Issues and Options in China's Greenhouse Gas Emissions Control" was issued on 29 March 1995 by the World Bank, the UNDP and China's National Environmental Protection Agency. The report predicted a sea-level rise of up to 70 centimetres off Shanghai and 60 centimetres off the Pearl River delta region by 2050 , threatening 92,000 square kilometres of land and displace 76 million people. The inundated areas would include 14 cities and counties in the Pearl River delta and 34 cities and counties in Eastern China.

China's main contribution to global warming is its 76 percent dependency on coal as an energy source, causing it to account for 10 percent of the world's carbon dioxide emissions. China's demand for the fuel would even triple to 3.1 billion tons by 2020 .

Meanwhile, a study published by the East-West Center at Hawaii and coinciding with the UN global climate conference at Berlin in April, 1995, forecast that the AsiaPacific region in 2010 will be the source of nearly half the global greenhouse gas emissions.

At the Berlin conference a group of developing countries, including China and India, backed a proposal enabling them to avoid any new commitments on cutting greenhouse gas emissions while richer countries would be asked to make more cuts.

At the 1992 Earth Summit a number of industrialized countries pledged to cut emissions to 1990 levels by the year 2000. The European Union indicated at Berlin that it would be prepared to cut emissions by further 10 percent between 2000 and 2010. On the other hand, the US, being the biggest producer of carbon dioxide, refused to commit to any further reduction next century. The US was supported by other leading carbon dioxide producers, including Japan. (IHT 31-03 and 05-04-95)

\section{Implementation of the Montreal Protocol 1987}

Malaysia would have phased out 693 tonnes (out of 1,500 tonnes phased out by all developing countries) of ozone-depleting substances (ODS) by May 1995 under the UNDP's Montreal Protocol. Malaysia was currently the second largest recipient of UNDP funds after China to finance phasing-out projects by local industries. (NST 0804-95)

\section{Caspian Sea}

Five littoral states of the Caspian Sea, Russia, Kazakhstan, Azerbaijan, Turkmenistan and Iran on 23 April 1995 launched a UN-backed effort to protect the Caspian Sea from pollution, oil projects and illegal fishing, and decided to draw up an environmental action plan. (IHT 24-04-95)

\section{ASEAN Co-operation Plan on Transboundary Pollution}

The Plan was adopted on 18 June 1995. It was prepared in connection with the haze that engulfed Malaysia, Indonesia and Singapore from August to October 1994. The Plan addresses three major areas of transboundary pollution: atmospheric, ship- 
borne and the movements of toxic and hazardous wastes, and spells out the strategies to prevent, manage and combat the three areas of pollution. It also identifies the areas of cooperation each participating country could concentrate on and the mechanism to monitor the implementation of the plan.

Atmospheric pollution is given more emphasis mainly because haze is the region's main problem, with forest fires, particularly in Indonesia, identified as a major contributing factor. (NST 15-06, 17-06, 18-06-95)

\section{Sino-Indian Protocol on Tiger Conservation}

The Protocol was signed on 2 March 1995. Its Article IV says that the two countries will "encourage on an experimental basis captive breeding activities with a view to release the species into the wild". The agreement calls upon the two states to "crack down on the illegal activities of poaching of tiger, smuggling and selling tiger, tiger bones and other parts of tiger as well as derivatives". The two countries agreed to establish bilateral research and training programmes and exchange technologies and research data for "the management of the tiger and its habitat".

This was a remarkable change in Chinese policy. China stayed away when the Global Tiger Forum, held in India in 1994, drew up an action plan.

Eighty percent of Asia's estimated 5,000 surviving tigers are in India, all belonging to the Royal Bengal sub-species. Conservationists believe there are about 400 each of the Siberian, Indonesian and Sumatran sub-species, and about 100 of the South China sub-species. (FEER 08-06-95 p. 26)

\section{ESPIONAGE}

Japan

Australian news reports alleged that Japan had mounted a high-tech spying operation to gather information from the Australian embassy at Jakarta. The report was denied by the Japanese. (IHT 26-05-95)

\section{Australia}

According to Australian television of 26 May 1995 Australia installed eavesdropping devices into the Chinese embassy in Canberra during the construction of the embassy in the late 1980s, on behalf of a US-led spying effort. The information was transmitted to a receiver at the rear of the British High Commission and relayed to the US National Security Agency. (IHT 27/28-05-95)

According to Australian news reports Australia mounted widespread and systematic spying against the Japanese embassy in Canberra. It was alleged that surveillance and eavesdropping had also been conducted at other embassies, including those of Indonesia, Iraq, Malaysia and Russia. (IHT 30-05-95) 
EXCLUSIVE ECONOMIC ZONE

(see: Territorial claims and disputes)

\section{FISHERIES}

(see also: Territorial waters)

\section{Fishery incident in Vietnamese waters}

Chinese fishermen caught while fishing illegally in Vietnamese waters fired shots at a Vietnamese patrol boat on 3 July 1994 . The incident occurred about five kilometres southeast of Ma Chau island in the Tonkin Gulf off Vietnam's Quang Ninh province. (FEER 14-07-94 p. 13)

\section{Illegal fishing in Malaysian waters}

A magistrate's court in Ipoh imposed a fine of RM1 million on the captain of an Indonesian fishing boat and RM500,000 on each of his four crew members on 22 September 1994 for illegally fishing in Malaysian waters about 34 nautical miles west of Pangkor Island. The court further ordered the confiscation of the fishing boat, equipment and catch.

On 1 April 1995 a magistrate's court in Kuala Terengganu fined the captains of two Thai fishing boats RM500,000 each, in default three months imprisonment, for encroaching into Malaysian waters. Ten of their crew were fined RM20,000 each, in default two months imprisonment, while two who were underaged were let off with a warning and ordered to be deported. The fishing boats and equipment were ordered to be confiscated.

On 9 April 1995 marine police detained three foreign fishing boats and 90 fishermen for encroaching into Malaysian waters about 70 nautical miles north of Pangkor Island. Some 2,800 kg. of fish found on board were seized.

Fourteen Thai fishermen in two fishing boats were detained in two separate incidents off Bachok, Kelantan on 5 May 1995. It was reported that the fishermen would be charged under section 15(1)(a) of the Fisheries Act 1985 which carries a maximum fine of RM1 million or six months imprisonment or both upon conviction. The boats and equipment would also be liable to confiscation. (NST 23-09-94, 11-0495; Star 02-04 and 06-05-95)

\section{Russo-Japanese fisheries pact}

Japan and Russia agreed to negotiate a fisheries pact that would allow Japanese fishing boats operate safely near the disputed 'Northern Territories' (referring to four disputed islands northeast of Hokkaido). (FEER 08-12-94 p. 13) 


\section{Release of detained Thai fishermen}

India released 51 Thai fishermen in December 1994. They were caught fishing in waters off the coast of Orissa state. (BP 16-12-94)

\section{Thai-Vietnamese Joint Committee on Fisheries}

The Thai-Vietnamese Joint Committee on Fisheries and Order at Sea, established by an agreement which entered into force on 10 November 1994, held its first meeting in Phuket on 10-11 March 1995. It was decided that nationals of both states have free access to fishery resources in the area of the Gulf of Thailand which is claimed by both states, and of which both states agreed to undertake joint assessment and management. The meeting also agreed in principle to establish joint patrols in the Gulf of Thailand.

Despite these arrangements several Thai fishing vessels were arrested by the Vietnamese in April and May 1995 (as were other Thai fishing boats by Malaysia and Myanmar). These resulted in Thai demands for their release and compensation, and in fire exchanges between Thai and Vietnamese naval vessels. As to the 31 May incident, Thailand said that it occurred 213 kilometres east of the southern Thai coastal town of Songkhla, which would put it within Thailand's exclusive economic zone. The Vietnamese said only that the incident occurred within its southwestern territorial waters.

On 7 June 1995 the Vietnamese authorities decided to release all the Thai fishing vessels and crew without any condition. (KK; FEER 15-06-95 p. 16)

[Note: In view of the forfeiture of foreign fishing vessels and the imprisonment of foreign fishermen by some states, on the offence of violating fisheries laws and regulations in the exclusive economic zone Thailand issued a statement on the matter on 3 May 1993. The statement recalled that such forfeiture and imprisonment are in breach of Art. 73, paragraphs 2 and 3, of the 1982 Convention on the Law of the Sea, and accordingly Thailand registered a strong protest through the UN Secretary General as the depositary of the Convention. (UN doc. A/48/936, annex)]

\section{FOREIGN INVESTMENT AND TRANSNATIONAL CONTRACTS}

(see also: Joint development; Oil and gas)

\section{Liberalization of Taiwan regulations}

The (Taiwan) Central Bank of China announced that existing curbs on foreign investment in local securities and bond markets would be lifted, allowing a free choice of any security and eliminating a 10 percent ceiling on bond investments. The ceiling was intended to prevent large inflows of offshore funds seeking to gain from the relatively high interest rates, thus affecting the bank's ability to conduct monetary policy. (IHT 18-07-94) 


\section{Investment in the field of aircraft-production}

It was announced on 8 August 1994 that Boeing Co. would start a series of projects in China, from component manufacture to jet servicing. In 1993 one-seventh of the aircraft production by Boeing in the US was delivered to China. (IHT 09-08-94)

\section{Malaysian investment guarantee agreements}

Malaysia concluded the following investment guarantee agreements in the past year: Namibia (5 August 1994), Argentina (6 August 1994), Jordan (2 October 1994), Bangladesh (12 October 1994), Spain (4 April 1995). It was agreed with Turkey to sign a similar agreement shortly. (NST 15-08, 08-09, 03-10, 13-10-94, 05-04-95; Star 16-08 and 30-09-94)

\section{Malaysian government contracts with British firms}

Malaysia on 7 September 1994 lifted a ban on awarding government contracts to British firms. The ban was imposed on 25 February 1994 after British media reports alleged that senior Malaysian politicians were taking bribes for awarding contracts to British business. Malaysia had also objected to allegations that there be links between a British loan for the Pergau Dam in Kelantan, Malaysia, and the Malaysian government's purchase of British defence hardware worth 1 billion pounds Sterling in 1988.

In recent months Britain sent at least nine trade missions to Malaysia in attempting to persuade the Malaysian government to end the ban. (IHT 08-09-94)

\section{Indonesian natural gas exploration}

(see also: 3 AsYIL, 381)

An agreement on the exploration and exploitation of one of the world's biggest gas fields was signed on 16 November 1994 by Exxon Corp., the Indonesian government and Pertamina, the Indonesian state oil company. The project is estimated to cost up to $\$ 40$ billion. The gas field, called D-Alpha Block, is located about 1,200 kilometres north of Jakarta and 225 kilometres northeast of the Indonesian Natuna Island in the South China Sea. The field extends 25 kilometres on one direction and 15 kilometres in another, and is estimated to contain 210 trillion cubic feet of gas, of which only 45 trillion cubic feet is considered recoverable because of its heavy mixture with carbon dioxide which is expensive to separate. The first deliveries were unlikely to take place before 2003.

The project is owned 50-50 by Pertamina and Esso Exploration and Production Natuna Inc. This is an exception of usual practice whereby Pertamina takes a 60 percent share. (IHT 11 and 17-11-94; NRC 12-11-94; FEER 17-11-94 p. 69) 


\section{Vietnamese iron ore mining}

It was reported that Krupp of Germany, Lonrho PLC of Britain and a third, undisclosed South African company were close to signing a $\$ 1.3$ billion contract with Vietnam Steel Corp. to mine iron ore in northern Vietnam. The proposed mining site is estimated to contain 300 million tons of commercially viable ore. The investment of $\$ 1.3$ billion would be required over a period of 30 years. (IHT 17-11-94)

\section{Foreign access to Chinese oil market}

It was reported that China had started discouraging foreign investments for new oil refineries. While construction of new refineries would be a waste because many of the existing refineries were underused, it was said that the policy could stem from a basic reluctance to open the domestic market to foreigners. (IHT 01-12-94)

\section{Protection of overseas Chinese foreign investment}

It was reported that China was considering legislation to protect investments by overseas Chinese. Eighty percent of foreign investment has been by ethnic Chinese living overseas and Chinese with foreign citizenships. (IHT 29-12-94)

\section{Sihanoukville region development program}

On 2 January 1995 the Cambodian government signed an agreement with a Malaysian company, Ariston Sdn.Bhd., which would undertake a \$1 billion development programme for the Sihanoukville region. The agreement would constitute the largest single investment to date in Cambodia. (NST 03-01-95)

\section{Expansion of European Toyota production}

Toyota Motor Corp. announced that it would double its production in the UK by building a second factory there. The new plant would eventually bring Toyota's British production to 200,000 cars a year. Toyota was facing the prospect of a strong yen cutting into profits from exports from Japan. (IHT 17-03-95)

\section{Japanese participation in China telecommunication}

It was reported that Japanese companies and government agencies will join in the upgrading of telecommunications in the Yangtze River area in China, and thereby invest 467 billion yen ( $\$ 5.2$ billion). The project would connect the cities of Shanghai, Nanjing and Hangzhou. A financing method called "build, lease and transfer" was being considered. (IHT 21-03-95) 


\section{Korean investments in China}

According to the Korean Foreign Trade Association South Korean firms had invested $\$ 1.7$ billion in China in 1994. China accounted for almost $17 \%$ of South Korea's direct foreign investment. (FEER 30-03-95 p. 73)

\section{Raising of foreign ownership limit in Korea}

The ceiling on foreign ownership of local stocks would be raised on 1 July 1995 from $12 \%$ to $15 \%$. The limit on state-owned firms would increase from 8 to $10 \%$. (FEER 18-05 95 p. 99)

\section{Japanese investments in Asia}

Japanese direct investment in the rest of Asia rose 47 percent in the past fiscal year ending 31 March 1995, as a result of the increased shift of production overseas because of the appreciation of the yen. Asia overtook Europe as the second-biggest recipient behind North America. (IHT 17-05-95)

\section{Malaysian investment in South Africa}

Malaysia, Australia and South Africa signed a memorandum of understanding on 19 May 1995 for a housing programme to be implemented in South Africa. Under the memorandum, a Malaysian-led consortium would embark on a pilot project for the building of about 600 low-cost houses. (NST 26-05-95)

\section{Review of Indo-US investment agreement: the Enron case}

The newly elected government of the Indian state of Maharashtra started an inquiry into a $\$ 2.8$ billion agreement for the building of a power station, concluded in 1994 between the Texas-based Enron Corp. and the previous (Congress Party) state government. The 2,015 megawatt-plant would be built by a US consortium on India's west coast.

The investigation concerned the question of how the contract was awarded to Enron and the new plant's costs to the state. A major source of opposition to the project was a guarantee given by the Indian federal government to Enron on fixed returns for foreign investors in power projects. Reports of 28 June 1995, which were denied by the review panel chairman, said that the panel had recommended the cancelation of the project without compensation. The same reports mentioned violation of the Indian Electricity Act and the Electricity Distribution Act as grounds for the cancelation. The state government would take a decision in July 1995. (IHT 06 and 29-06-95)

\section{Malaysian rejection of Indonesian-Malaysian corporate deal}

One year after the conclusion of an agreement linking the Indonesian timber enterprise P.T. Barito Pacific Timber with the Malaysian Construction and Supplies 
House Bhd the deal, already approved by the Malaysian Foreign Investment Committee and the ministry of foreign trade and industry, was rejected by the Securities Commission. (IHT 29-06-95)

\section{Investment climate in Asian countries}

A survey carried out by the East-West Center in Hawaii among international companies interested in investing in power plants and coal mines presented a rating of 13 Asian economies according to their investment climate. It placed China next to last, just ahead of Vietnam. India was fifth from bottom, ahead of China because of its western-style legal system and clearer terms for private investors. The survey found that Australia, Indonesia, Thailand, Malaysia and Taiwan had the best overall investment conditions. (IHT 30-06-95)

\section{GENERAL AGREEMENT ON TARIFFS AND TRADE (see also: World Trade Organization)}

\section{The issue of China's re-entry}

The 18th round of talks on China's re-entry started in late July 1994. One of the main issues was the US insistence that China not be admitted with developing country status. This status included special provisions in areas such as farm products and the protection of infant industries. Other US demands were: more access for US service industries, the removal of non-tariff trade barriers, and the closure of 26 factories producing pirated compact discs for export. (IHT 28-07-94) In December 1994 the talks were postponed till February 1995. (IHT 23-12-94)

\section{GROUP OF 77}

\section{Communique of the Group of 77 and China}

The Chairmen/Coordinators of the Chapters of the Group in Geneva, Nairobi, New York, Paris, Rome, Vienna and Washington D.C. adopted a communique in 1995 in which the commitment to the objectives of the Group was reaffirmed. (UN doc. $\mathrm{TD} / \mathrm{B} / 41(2) / 13)$

\section{HONG KONG}

(see also: Divided states: China; Judicial assistance)

\section{Dispute over electoral reforms shelved}

The British Minister for Hong Kong Affairs visited China in July 1994. He was the highest-ranking British foreign affairs official to visit China in a year and the visit 
marked a shelving of the dispute over electoral reforms in the colony. (IHT 08-07-94)

\section{Transfer of military sites}

After seven years of talks China and the UK reached agreement about the transfer of military sites. The two parties agreed on 30 June 1994 that 14 out of 39 military properties in Hong Kong would be handed over to the Chinese armed forces, while the others would be sold and used for eventual commercial development when the British forces leave in 1997. As part of the deal Hong Kong would build a new naval base to replace the existing facility. (IHT 01-07-94)

\section{The airport issue}

It was announced that China and the United Kingdom had reached basic agreement on the financing of the projected new airport. China agreed with a fourth British financing proposal, based on $\$ 7.8$ billion government equity and $\$ 23$ billion of debt. (IHT 10-08-94) Agreement on a general formula for the financing was reached on 3 November 1994 and an 'agreed minute' was signed a day later. (IHT 04-11-94)

On 29 March 1995 agreement was reached on forming a body to borrow the necessary funds. The points of controversy included the name of the airport managing body and the nationality of the senior executive. (IHT 30-03-95)

\section{Disbanding of Hong Kong legislature and its replacement by a provisional legislature}

The Standing Committee of the Chinese National People's Congress voted on 31 August 1994 to disband Hong Kong's legislature and other elected institutions when the colony reverts to Chinese rule in 1997. The proposal to disband was submitted in March 1994 by legislators from Guangdong Province. (IHT 01-09-94) Consequently provision had to be made for its replacement on 1 July 1997 by a provisional legislature, in anticipation of the first legislature in accordance with the provisions of the Basic Law. The provisional legislative council would be formed by a selection committee. The idea of a provisional Legco was first raised in early October 1994 by the Preliminary Working Committee, an advisory body appointed by the Chinese government. (The PWC is the precursor of the Preparatory Committee which under an NPC decision is due to be established in 1996). (IHT 8/9-10-94; FEER 24-11-94 p. 26; 08-12-94 p. 32)

\section{Award of government contracts}

China accused the Hong Kong authorities that they awarded a major stake in a giant container terminal project to the Jardine Matheson corporation in return for political backing of the Governor's program of electoral changes. (IHT 15-09-94) 


\section{Status of Hong Kong residents}

(see: 1 AsYIL 302; 3 AsYIL 387)

According to an oft-quoted estimate the number of foreign passport-holders in Hong Kong was 400,000 in a total population of 6 million. Besides there were those who did not yet have a foreign passport but had the right to enter another country in the future, like the households who will be granted full-fledged British passports under the British Nationality Scheme (see: 1 AsYIL 302).

Among those with British affiliation a distinction had to be made between persons with a full-fledged British passport, a British National Overseas (BNO) passport and those who are British Dependent Territories Citizens (BDTC), the two latter categories not being eligible for the right of abode in the United Kingdom.

Against this backdrop the Preliminary Working Committee had been discussing the political rights of ethnic Chinese with foreign passports after the take-over in 1997. The Basic Law allows persons who will be Hong Kong citizens still to use a British National Overseas passport as a travel document abroad. It also prescribes that, apart from the chief executive, senior civil servants and top judges must be Chinese Hong Kong residents without a right of abode overseas. However, it does not specify nationality requirements for most civil servants, and the Law also allows up to $20 \%$ of the membership of the Legislative Council to be filled by non-Chinese or Hong Kong Chinese with a right to abode overseas. (FEER 29-09-94 p. 20; 15-06-95 p. 21)

\section{Final Court of Appeal}

(See: 2 AsYIL 320)

In 1991 agreement was reached between China and the UK to create a Final Court of Appeal as the ultimate court for Hong Kong, replacing the Privy Council as the highest tier of the judicial system in Hong Kong. The court would have final adjudication over all cases, except those relating to defence and foreign affairs.

It was reported in late February 1995 that the UK was unilaterally preparing the establishment of the Court in 1996. (IHT 28-02-95) Until June 1995 it was the policy of the colonial government to have the new court established before 1997. (IHT 09-0695) Agreement was finally reached on 9 June 1995 after China offered a compromise. The agreement largely mirrored earlier proposals. Under the agreement the court will function from the re-establishment of Chinese rule in 1997. China dropped its concerns about the court's competence to examine constitutional questions, and agreed to limit the government's post-verdict remedial actions on the findings of the court to criminal cases only. However, the agreement specified that acts of state, such as defence and foreign affairs, would fall outside the jurisdiction of the court. (FEER 13-10-94 p. 30; 22-06-95 p. 20; IHT 10/11-06-95)

\section{Incursions in territorial waters}

Chinese patrol boats had captured persons suspected of smuggling in the waters between Hong Kong and the mainland. The Governor ordered the police and the British navy to get tough on marauding Chinese boats, accusing the latter of illegally entering 
Hong Kong waters. This was denied by the Chinese side who said that it was not unusual for vessels from either side to inadvertently enter the other's territory.

Hong Kong called for the release of the men, while the Chinese side said that the detainees and their boats would be released only if investigations showed they were not involved in illegal activities in Chinese waters. (IHT 31-03-95)

\section{US warnings}

In the boldest US warnings yet to China over the treatment of the territory after its reversion to Chinese rule, the US consul-general and the Assistant Secretary of State for East Asia expressed US apprehensions over excessive control of Hong Kong's economic and social freedoms. (IHT 26-05-95)

\section{Status of civil servants after 1997}

China declared that Hong Kong civil servants were welcome to continue serving through the transition under existing conditions, and pledged not to place mainland Chinese officials in their ranks. The termination of expatriate privileges was mentioned as one of the few changes envisioned by China for the Hong Kong civil service. (IHT 26-06-95)

\section{HOT PURSUIT}

\section{Cambodian forces on Thai territory}

Cambodian forces, straying into Thai territory in hot pursuit of Khmer Rouge rebels, killed two Thai soldiers on 28 February 1995. Thereupon Thai forces hit back and killed a number of Cambodian soldiers. (FEER 16-03-95 p. 13)

\section{Myanmar forces on Thai territory}

Forces of the Democratic Kayin Buddhist Army together with government Myanmar troops made incursions into Thai territory in trying to force Karen refugees across the Thai border back into Myanmar. As a result the Thai army warned Myanmar it would retaliate and on 5 May 1995 Thai forces indeed launched a cross-border attack on Myanmar guerrillas on the west bank of the Salween River opposite the Thai village of Mac Sam Leap. (IHT 04 and 05-05-95)

\section{IMMIGRATION AND EMIGRATION \\ (see also: Aliens)}

\section{Vietnamese Immigration Law}

An immigration law was passed by the Cambodian parliament in August 1994. 
(IHT 27/28-08-94) (see also: Minorities)

\section{Illegal immigrants in Malaysia}

There were several reports of Indonesian illegal immigrants whose boats capsized resulting in those who managed to get ashore being arrested. (NST 14-11-94, 13-04-95; Star 13-04-95)

The Malaysian Immigration Department detained nearly 50,000 foreigners in 1994 for various offences such as illegal entry, overstaying and failure to abide by the conditions in the immigration passes. Of those detained, 28,378 were Indonesians, 10,993 were Bangladeshi, 3,319 were Myanmar nationals, 2,701 Filipinos and 1, 129 Thais. Those detained were deported to their countries of origin. (NST 06-03-95)

\section{Admittance of illegal aliens}

The Philippine president signed the Alien Social Integration Act on 24 February 1995, granting about 100,000 to 500,000 illegal aliens, mostly Chinese and Indians, the right to remain in the Philippines. The Act covers foreigners who entered the country before 30 June 1992. (IHT 25/26-02-95)

\section{Chinese illegal immigrants in Japan}

In 1993 the number of Chinese caught attempting to enter Japan illegally was 5,227 , an increase of $51 \%$ from 1992 . As of the end of 1993 there were around 36,300 Chinese nationals living illegally in Japan. (FEER 04-08-94 p. 20)

\section{INSURGENTS}

\section{Offer of Myanmarese warlord to surrender}

U KHUN SA, the 'Golden Triangle' opium warlord, who declared independence for a Shan state in northeastern Myanmar, on 16 July 1994 offered to surrender in exchange for a withdrawal of the Myanmar military forces from the territory concerned. (FEER 28-07-94 p. 13) In January 1995 it was reported that the Myanmar government was on the verge of a major offensive against the so-called Shan or Mong Tai army. (IHT 28/29-01-95) KUN SA was accused by the government to hide his drug trafficking operations by claiming himself to be a liberation fighter by seeking independence for the Shan minority and forming the Shan State National Congress in December 1993. (IHT 03-04-95)

\section{Bodo insurgence in India}

An insurgence broke out among the Bodo in the Assam region of India. In February 1993 the federal government, the government of Assam state and several 
representatives of the Bodos signed an accord giving the group limited political and administrative autonomy and establishing a Bodoland Autonomous Council. But the area kept being plagued by sporadic bloodshed. The accord collapsed and tension increased between the Bodos and the much larger population of Muslim immigrants who had fled Bangladesh and Hindus from other parts of India or from Bangladesh. This majority feared that a Bodo minority administration would subject them to discrimination. From July 1994 rebels from the Bodo Security Force burned villages and attacked villagers. The Bodo militants reportedly withdrew to neighbouring Bhutan when pressed by the army.

The Bodo offensive is part of a widespread tribal agitation in northeast India ever since a group of non-indigenous politicians allowed a large influx of foreigners into the area. It was said that the Bodo militants had established links with other underground organizations such as a faction of the National Socialist Council of Nagaland, and that there was a move to internationalize the issue. (FEER 01-09-94 p. 26)

\section{Tamil insurgence in Sri Lanka}

The conflict existed since 1972 and had taken 34,000 lives so far. [Part of] the Hindu Tamil minority demanded a homeland in the north and east of the country, and accused the majority Buddhist Sinhalese of discrimination in jobs and education. Tamils make up 18 percent of the population of 17 million. The Liberation Tigers of Tamil Eelam have been involved since July 1983 . They started attacking Muslims and Sinhalese civilians in 1990, but ceased doing so after 1992, to concentrate instead on politicians and army personnel. On 26 May 1995, however, they killed tens of people in an attack on a fishing village.

Sri Lanka lifted an economic embargo on Tamil guerilla-held territory on 31 August 1994 and called for peace talks. The Tamil rebel leader accepted the government offer for unconditional peace talks on 3 September. (IHT 01 and 05-09-94, 27/2805-95)

Government officials and Tamil separatist rebels ended their first round of peace talks in Jaffna on 14 October 1994. Among the rebels' requests were a cease-fire, safe passage for travellers and the easing of economic hardships. (IHT 15/16-10-94) The talks were suspended by the government when the rebel movement was implicated in the bombing of the opposition presidential candidate on 24 October 1994, but were resumed in early January 1995 . (IHT 03-01-95) On 3 January agreement was reached to cease hostilities as a prelude to a formal cease-fire agreement. (IHT 04-01-95) The agreement included a halt in offensive operations on both sides, a neutral zone separating the warring forces and six international observer teams to monitor the 'noman's land'. The truce became effective on 8 January 1995 and would last till 22 January. (IHT 7/8-01-95)

On 6 March 1995 the government announced that the leader of the rebels had rejected a presidential offer to invite "a foreign person under the patronage of a foreign government" as a mediator to open substantive political talks between the government and the rebels. He preferred direct talks between the parties. (IHT 07-03-95)

In April the rebels decided that the government had not sufficiently met their demands for further peace talks, and broke the truce by sinking two government 
gunboats. The security forces thereupon reimposed an embargo against the rebel-held territories. (IHT 20-04-95)

On 17 May 1995 five Tamil parties, among which former militant groups, held talks with the president of Sri Lanka to find a way to end the country's ethnic conflict. The meeting was not attended by the moderate Tamil United Liberation Front who refused to sit together with former militants.

\section{Bougainville insurgence}

(see: 1 AsYIL 308)

The rebellion began in late 1988. A peace accord was reached in 1991 but came to nought. In 1994 new talks were started on 27 August with a timetable for a ceasefire. The PNG government and the leaders of the Bougainville Revolutionary Army set an agenda involving the possible creation of a South Pacific peacekeeping force to oversee the ceasefire, normalization of communications, amnesty and compensation, as well as the holding of a pan-Bougainville peace conference before the end of the year. A cease-fire accord was signed on 8 September 1994 in Honaria, Solomon Islands, and it was agreed to hold a conference before 10 October.

One of the focal points of the conflict had been the Panguna copper mine on Bougainville Island, which was controlled by the Australian mining firm CRA. The mine used to provide about $20 \%$ of PNG's government revenue and $44 \%$ of export earnings. It was closed by the secessionist rebels in 1989. (IHT 09-09-94; FEER 08-0994 p. $60 ; 15-09-94$ p. 21 )

\section{Indian support for Sri Lankan government fight against insurgents}

The Indian responded favourably to Sri Lankan government calls by establishing a naval quarantine around the guerilla stronghold at Jaffna: the Indian forces enforced an embargo across the Palk Strait which separates the two countries at India's southeastern tip. According to newspaper reports the operation had even extended further into the Indian Ocean in an effort to seal off the northeastern coast of Sri Lanka and thus to prevent the insurgents from being supplied with weapons and fuel. (IHT 2006-95)

\section{Peace talks with Communist insurgents in the Philippines}

The Philippine president in a statement released on 16 October 1994 expressed regret that preliminary talks between a government panel and exiled leaders of the National Democratic Front in the Netherlands had broken down, and urged the rebel leaders to resume the talks. (IHT 17-10-94)

The failure of the talks found its origin in a 1989 document drafted by the Communist Party of the Philippines (CPP) chief JOSE MARIA SISON who is in self-exile in the Netherlands. In the document the communist-led National Democratic Front (NDF) was described as "a belligerent force in the civil war and not a mere insurgent force". It continued by stating: "It cannot negotiate with the reactionary government if not on an equal footing under international law". Accordingly the NDF negotiators 
demanded that the draft agreement would allow it to issue safety and immunity guarantees to government officials entering rebel-held areas. This was rejected by the government as it would implicitly acknowledge a status of belligerency under international law. In fact the communist New People's Army had shrunk considerably as had the CPP's active membership, and what remained of the territories controlled by them were pockets in the mountainous Bicol area of southern Luzon, the Vsayas island of Samar and the three southwestern provinces in Mindanao. (FEER 27-10-94 p. $13 ; 10-11-94$ p. 20 )

New negotiations were announced in May 1995, to be held in Brussels in June but these were later postponed indefinitely by the NDF after the arrest of a ranking guerilla leader. (IHT 13/14 and 22-05-95) The talks were actually resumed on 26 June 1995 with a NDF demand for the release of the arrested commander in order to allow him to join the talks. According to the NDF he was covered by an agreement to protect members of the negotiating teams from arrest or capture. The government denied this as his name was not received in time, and suspended the talks. (IHT 27 and 28-06-95)

\section{Muslim insurgence in the Philippines}

There are two Muslim insurgent organizations, the Moro National Liberation Front (MNLF) led by NUR MISUARI, and the Moro Islamic Liberation Front (MILF), led by SALAMAT HASHIM, which split from the MNLF in 1978. The latter has a standing army, the Bangsa Moro Islamic Armed Forces and acts as a shadow government in many Muslim-majority areas of seven provinces of Mindanao.

So far the Philippine government had directed most of its attention to and held peace talks with the MNLF whose territory was confined largely to the Sulu archipelago. The MNLF had signed the so-called Tripoli Agreement of 1976, made under the auspices of the Organization of Islamic Conference. Under this agreement the Philippine government had committed itself to grant autonomy to 13 provinces and nine cities with a Muslim majority, covering nearly all of central Mindanao as well as Palawan Island. While the MNLF insisted on implementation of the agreement, the government held the view that autonomy had already been granted when the Autonomous Region for Muslim Mindanao was established in 1990, consisting of the four provinces of Sulu, Tawi-Tawi, Maguindanao and Lanao del Sur, plus Marawi City. (FEER 23-02-95 p. 22-28)

Talks started again on 19 June 1995 in Davao between the government and the MNLF. During these talks the insurgents demanded control over the entire southern part of the Philippines, including Palawan, Mindanao and nearby islands. This would be in accordance with the Tripoli agreement. There had been a cease-fire in force since late 1993.

A settlement of the Muslim insurgence was seen as the answer to the extremist Islamic movements, such as the break-away insurgent faction 'Abu Sayyaf'. In contradistinction to the MNLF, Abu Sayyaf aims at the establishment of an independent Islamic state in the Philippine southern islands. (IHT 21-06-95)

A sixth round of discussions was planned for 27-29 July in General Santos City. (IHT 24/25-06-95) 


\section{Kayin (Karen) and Karenni in Myanmar}

During the talks between representatives of the government of Myanmar and the UN Secretary-General (see Human rights) reference was made to a rift among the Karenni National Progressive Party and a schism in the Karen National Union and the establishment of a rival force under the name of the Democratic Kayin Buddhist Organization in December 1994. (UN doc. A/50/782)

On 26 January 1995 the Myanmar army overran the jungle headquarters of one of the Karen rebel groups at Manerplaw, which was also the rallying point for the All Burma Students' Democratic Front and other opponent groupings. It was followed by the fall of other bases along the Thai-Myanmarese border. (IHT 28/29, 30 and 31-0195)

The Democratic Kayin Buddhist Army, together with government troops, later tried to force Karen refugees across the Thai border back to Myanmar into government-held territory. (IHT 15-02-95, 02-05-95) As a result of these incursions into Thai territory the Thai army announced it would move thousands of Karen refugees from the frontier to new sites 10 kilometres inside Thai territory. (IHT 04 and 05-05-95) In June it was reported that the Karen National Union expressed its desire to continue peace talks with the government. (IHT 13-06-95)

Members of the Karenni National Progressive Party on 21 March 1995 responded to a government call for reconciliation and turned over a great many weapons in a formal ceremony in the capital of Kayah state, northeast of Yangon. With this event fourteen of the sixteen major ethnic insurgent groups had come to terms with the government. (IHT 22-03-95)

\section{INTELLECTUAL PROPERTY}

\section{Thailand - US}

The US secretary of state said his country would remove Thailand from a 'priority watch list' of countries considered to be guilty of intellectual property violations, following the Thai Parliament's approval of a new copyright law. (FEER 01-12-94 p. 81)

[Note: The act took effect on 21 March 1995. It does not explicitly state that using pirated software is an infringement of copyright. It exempts software from copyright protection if its use doesn't "unreasonably prejudice the lawful rights of the owner". The law allows for a maximum fine of 800,000 baht and a maximum jail term of four years. (FEER 15-06-95 p. 66)]

\section{China - US}

The US announced the launching of an investigation into allegations of patents and copyright piracy in China and on 30 June 1994 threatened to apply trade sanctions for such piracy allegedly covering $\$ 800$ million in lost sales annually. (IHT 01-07-94) 
[On 17 January 1992 China and the US signed a Memorandum of Understanding on the Protection of Intellectual Property. 34 ILM 676 (1995)]

It set two deadlines for China to comply with bilateral agreements on trade issues or face sanctions: 30 December for the curbing of violations of US copyrights and patents, and 31 December for adherence to a 1992 market-access agreement. (IHT 14 and 17/18-12-94) Prime targets for punitive tariffs by the US included shoes, toys, sporting goods, clothing, radios and suitcases made in China. (IHT 29-12-94)

On 30 December US sources referred to preparations for trade sanctions, immediately followed by Chinese threats for counter-retaliatory measures. On New Year's Eve the US issued a target list of $\$ 2.8$ billion in Chinese products and identified about $\$ 1$ billion worth of punitive, 100 percent tariffs. Actual sanctions would not go into effect until 4 February 1995, after a 30-day comment period, giving a chance to US importers to argue that sanctions in particular areas would cause extensive harm to US business and consumers. (IHT 31-12-94/01-01-95)

The talks were resumed on 18 January 1995 with China staunchly defending its protection of copyrights, patents and trademarks and the US insisting that China must act more decisively against major pirates of American products. (IHT 18 and 19-01-95) The US Trade Representative acknowledged a few days before the expiry of the negotiation period that a 'preliminary accord' was reached in some areas but insufficient to satisfy the US demands. (IHT 03-02-95)

On 4 February 1995 the US announced its sanctions, the largest trade sanctions in US history, to take effect on 26 February. This was immediately countered by an announcement of similar Chinese sanctions as of 26 February. These counter-measures were justified by reference to "sovereignty and national dignity". China also suspended imports of certain items and called off talks with US car producers. (IHT 06-02-95) Yet both parties decided to resume talks. (IHT 07-02-95)

The US wanted China to strengthen enforcement of laws and regulations protecting copyrights, patents and trademarks, in particular by closing down 29 factories that produce pirated compact discs. US business estimated a loss of at least $\$ 1$ billion a year to Chinese piracy. China maintains that it already made great progress. It announced 8 February 1995 that it had executed 12 people for producing fake goods in the past two years and vowed a tougher line against production of counterfeits. It accused the US of being unreasonable and of meddling in China's internal affairs. (IHT 09-02-95)

China and the US finally reached agreement which was signed on 26 February 1995 and which included a 20-page, single-spaced enforcement plan. Under the agreement China would inspect within three months 29 compact and laser disk factories and destroy pirated goods and equipment used to produce them. The accord also provided greater access for US recording and film to the Chinese market, and assurances about stiffer penalties for producers of pirated goods. (IHT 27-02-95)

It was reported in early June 1995 that six out of the seven compact disk factories had reopened. According to an official of the Chinese National Copyright Administration, the plants had indeed reopened but under the supervision of government officials. The official said that the intent of the agreement was not to close the plants forever, but to impose stiff fines and suspend production temporarily. (IHT 02-06-95) 


\section{Amendment of the Indian Patents Act}

On joining the World Trade Organization India was required to amend its Patents Act of 1970 (see 3 AsYIL 394), so that it allows patents not only for processes but also for products in the agricultural, chemical and pharmaceutical fields. (IHT 03-01-95; FEER 12-01-95 p. 81)

\section{Tokyo High Court decision on scope of first-sale doctrine}

The Tokyo High Court took a decision in a case involving Jap-Auto Products Inc. and the German company BBS Inc. Contrary to the historically accepted geographical scope of the first-sale doctrine which is limited to the country which granted the patent, the court ruled in case of a German product covered by German and Japanese patents, that a Japanese company could import the products in Germany and sell them at a higher price in Japan without violating the Japanese patent. Competitors could thus circumvent patents in their own country by importing the products concerned, produced cheaper in another country under a local patent. (IHT 18-04-95)

\section{Resolution of copyright cases in China}

On 18 May 1995 a Beijing court ordered three local publishers to pay $\$ 27,360$ to Walt Disney for unauthorized use of its cartoon characters.

The following week the US publishing concerns Prentice-Hall Inc. and Harcourt Brace won a court-mediated cash settlement and an apology from the Chinese state publisher Anhui Science and Technology Press who admitted pirating their works. The Association of American Publishers had filed suit in 1994 on behalf of the two publishers before the [new] intellectual property protection chamber of the Intermediate People's Court of Beijing.

It was said that courts often rejected claims based on what a plaintiff's property is worth outside China as such large amounts were inappropriate for Chinese to pay.

Furthermore local individuals often lack the resources required to start a court case, as the advance court fees are set proportionate to the claimed damages. Besides, bringing suit might imply the risk that the authentic products may also become tainted as possibly fake. (IHT 27/28-05-95; FEER 22-06-95 p. 80)

\section{INTER-STATE RELATIONS: GENERAL ASPECTS}

\section{Iran - US}

It was reported that the head of the US Central Intelligence Agency told the US Congress in 1992 that Iran was spending \$2 billion a year on arms, could pose a threat to the US and its allies in the Gulf within three to five years, and have a nuclear weapon by 2000 . In 1993 his successor told Congress that Iran would need 8 to 10 years to build a nuclear weapon unless it had extensive outside help. In 1994 US Ministry of Defense officials said that Iran spent only about $\$ 800$ million on arms in 1993 
and had made much less progress on its nuclear weapons program than expected. (IHT 06-07-94)

The US president made an announcement on 14 March 1995 on the issue of an executive order preventing an American oil company, through its subsidiary, from "entering into contracts for the financing or the overall supervision and management of the development of petroleum resources in Iran". The announcement was prompted by the announcement of an agreement between the Iranian government and Conoco Iran N.V., a Dutch affiliate of the Houston-based Conoco Inc. which is owned by E.I. Dupont de Nemours \& Company. The President would act for national security reasons under the International Emergency Economic Powers Act. Yet it appeared likely that the development of the oil fields would proceed, since two French oil companies (Elf Aquitaine and Total) and Royal Dutch/Shell had competed with Conoco for the project.

The US sought to isolate Iran economically and diplomatically because Iran allegedly supports terrorist groups, undermines peace efforts in the Middle East, seeks to dominate the Gulf region and endeavours to acquire nuclear weapons. Yet transactions relating to Iranian oil were allowed as long as they take place by foreign subsidiaries outside the US. (IHT 15 and 16-03-95, 22-06-95)

On 8 May 1995 the president of the US issued an executive order prescribing a total ban on US trade with and investment in Iran, taking effect in July 1995. Prior to this total boycott US companies were still allowed, through their foreign subsidiaries, to purchase Iranian oil (about 20 percent of the production at $\$ 3$ billion to $\$ 4$ billion) provided it was sold outside the US. However, even under the new executive order fully independent subsidiaries not controlled by US-based executives would not be affected. Under the ban Iran was not permitted to buy any US goods. (IHT 02-05 and 09-05-95) Since the announcement of the imminent order on 1 May fear of hyperinflation led to panic buying of US currency resulting in the rial losing more than a third of its value against the dollar. (IHT 10-05-95)

It was widely believed that it was primarily pressure from the US Congress that induced the president to take recourse to the tough policy option. Under a bill sponsored in the Congress US markets would be closed to most foreign corporations doing business with Iran. (IHT 03-05-95)

In a rare statement addressed to the US the Iranian president on 13 April 1995 called on the US to reconsider its policies on Iran. He explained US pressures to be partly based on Iran's rejection of Arab-Israeli peace efforts, qualified the US moves to isolate Iran as illegal and warned that they would lead to regional instability. (IHT 14-04-95)

In an interview with an American broadcasting company the Iranian president later said that the US missed a chance to improve relations by banning the Conoco-deal. "My suggestion to your government is not to do these immature things. ... We are not asking the United States to have relations with us. What we are asking the United States is to stop its hostility against us". (IHT 17-05-95)

A month after the US decree Iran had found other buyers for the 500,000 barrels of oil previously bought by US clients. 


\section{Relations between Asian Muslim states and Israel}

In June 1994 the brother of the king of Malaysia who is a businessman went to Israel for a private visit, but his schedule included meetings with the prime minister and the foreign minister. As this involved a violation of Malaysian law, the prince might face action by the Malaysian authorities upon return.

In the same month the Maldives for the first time allowed Israelis to visit the country, while Bangladeshi MPs met with senior Israeli officials when passing through Israel. (FEER 07-07-94 p. 28, 04-08-94 p. 13)

The Malaysian prime minister said that Malaysian recognition of Israel would be conditional upon the Palestinians and Arab countries 'being satisfied' with the implementation of their peace agreements with Israel. (FEER 13-10-94 p. 13)

Efforts to establish diplomatic relations met with another setback following Israel's negative vote against the UN General Assembly resolution granting the right to selfdetermination to Palestinians. However, Malaysian nationals were allowed to visit Jerusalem for religious purposes for not more than 14 days. (NST 10 and 20-11-94; Star 10-11 and 15-12-94)

\section{China - Germany}

The first European response to the US emphasis on Asia was by way of a visit by the German Chancellor to China in October 1993, ensuing a return visit by the Chinese Premier in July 1994 and the signing of $\$ 3.5$ billion worth of contracts with German companies. (IHT 07-07-94) The latter visit was, however, marred by a number of human rights demonstrations. (IHT 08 and 9/10-07-94)

\section{China - North Korea}

At an official gathering in Pyongyang the Chinese ambassador stressed the importance of Sino-Korean cooperation under the 1961 Sino-North Korean Treaty of Friendship and Mutual Assistance. Under this treaty the two countries are committed to offering one another immediate military and other assistance in the event of an attack on either by a third state. (IHT 09/10-07-94)

\section{Vietnam - US}

Vietnam gave new assurances of cooperation in determining the fate of missing US military personnel from the Vietnam War, but it was reported that these assurances were not considered satisfactory enough to justify a visit by the US Secretary of State who would be in Thailand in July 1994. (IHT 08-07-94)

After an agreement in principle signed in May 1994, the two countries finally decided on 28 January 1995 on the actual establishment of diplomatic relations through the opening of liaison offices.

The agreement also settled questions about compensation for diplomatic properties seized at the end of the Vietnam War in 1975. Vietnam would return or compensate for 36 US properties, and the US would turn over the former South Vietnamese 
embassy in Washington and unfreeze Vietnamese assets. (FEER 10-11-94 p. 12; 09-0295 p. 14; IHT 27-01-95) (see: Compensation)

The Vietnamese prime minister on 25 April 1995 called for normal diplomatic ties as well as full economic and commercial relations. The US had made a full accounting of still more than 2,000 US service men the determining factor for the pace of normalizing relations. (IHT 26-04-95)

\section{Myanmar - US}

It was reported that Myanmar officials had offered the US to bring down the drug baron KHUN SA against a lift of the US arms embargo. Myanmar is the source of most of the world's opium, and KHUN SA had been indicted on narcotic charges in the US in 1990. It was said that the Myanmar army needed arms and ammunition to destroy KHUN SA's stronghold and that the arms provided by China were not suitable for the mountainous terrain. Responding to these reports U KHUN SA, who is also head of the Shan State Restoration Council and commanding the Mong Tai Army, offered to surrender in exchange for a military pull-out from the northern part of the country and an independent Shan state.

In its annual report on drug trafficking the US State Department was critical of peace settlements between the Myanmar government and the ethnic groups of the Wa and the Kokang since they would permit the groups concerned to continue harvesting opium. (IHT 16/17 and 18-07-94)

The US sent a deputy Assistant Secretary of State to Myanmar in October 1994 to discuss human rights, democracy and the fight against narcotics. He delivered a message consisting of two visions of future relations. One would be increased cooperation with Myanmar based on positive movements on human rights, democratization and anti-narcotics activities. The other would be increased isolation if the Myanmar government failed to move forward in these three areas.

The US withdrew its ambassador from Myanmar in 1989 after the military takeover of the government in 1988. (FEER 10-11-94 p. 13)

\section{India - Russia}

The Indian prime minister visited Russia early July 1994. A path-breaking achievement of the visit was a joint declaration on protecting the interests of 'pluralistic' states, referring to threats to countries such as India and Russia from ethnic and religious sub-nationalism. The declaration stated, inter alia, that India and Russia had already exercised their right of self-determination. (FEER 14-07-94 p. 18)

\section{Cambodia - Thailand}

The outlawing of the Khmer Rouge (see supra p. 395) implied that the guerillas and their leaders should not be allowed to leave the country, including access to Thailand. The Cambodian government said it would ask other countries not to allow the Khmer Rouge to enter their territory and not to recognize other passports than those 
of the royal government. Thailand assured that it would abide by the new law. (FEER 21-07-94 p. 21)

On 2 July 1994 there was a coup attempt in Cambodia (see supra p. 395) led by a former interior minister, General SIN SONG, and there was suspicion of Thai involvement. The general was arrested but escaped two months later to Thailand. He was sentenced in his absence on 28 October 1994 to a prison term of twenty years. Nine Thais were sentenced on the same day to suspended prison terms of three to five years and were released for return to Thailand. (FEER 17-11-94 p. 16)

\section{China - US}

(see also: Unrecognized entities at p. 506)

On 27 August 1994 the US Commerce Secretary came to China on a mission to improve the prospects of US firms competing for business in China. It was the first visit by a US cabinet minister since the separation of the MFN-issue and human rights. (IHT 29-08-94)

For its part China pledged to resume the dialogue with the US over its human rights policy, which collapsed in February 1994. The US Commerce Secretary said he had raised US concerns "in ways that allow us to have some chance of success at achieving our goals. ... I haven't tried to bludgeon them about it. I haven't approached them with arrogance, but with concern, deep concern." (IHT 31-08-94)

On 7 September 1994 the US announced a change in Taiwan policy, reaffirming the US position that there is only 'one China', but loosening some of the strictures that had prevented US officials from carrying out direct talks with Taiwanese officials on trade and economic issues. For the first time since 1979 the most senior US official in Taiwan visited the Taiwan president to brief him on the policy change.

When the US announced changes in its Taiwan policy involving loosening some restrictions in contacts, China reacted by saying that the expansion of US official ties with Taiwan "seriously violated the three joint communiques signed between China and the US" and would seriously and adversely affect Sino-US relations. (IHT 09-and 1209-94)

China cancelled a planned visit by the US Transportation Secretary in January 1995 as a protest against the latter's trip to Taiwan in December 1994. This visit was considered to be in violation of the 1978 Sino-US agreement on the establishment of diplomatic relations. (IHT 14-12-94, 16-12-94)

In February 1995 the US Defense Secretary announced that the US was committed to maintaining "a stable forward presence in the [Asian] region, at the existing level of about 100,000 troops, for the foreseeable future". In order to avoid creating the perception that it was thereby trying to contain China much as it did the Soviet Union, the US adhered to a policy of 'constructive engagement' and accordingly started a program of exchanging information about the respective defence policies with China. (FEER 13-04-95 p. 30) 
In response to the US decision of 20 May 1995 to allow the Taiwanese president to visit the US (see: Unrecognized entities, at p. 504) China issued a denunciation on 23 May 1995 and demanded that the US reverse its decision. The Chinese statement equated the pending US visit by the Taiwanese president with his travels to various countries under the guise of 'private visits' and 'vacations' (see 4 AsYIL 430). In a later statement China accused the US of harming bilateral relations and of violating the communiques [of 1971 and 1978] establishing diplomatic relations. While the US maintained that since the visit was of a strictly private character it did not violate the US pledge to recognize only 'one China', China contends that any visit by the Taiwanese president would undermine the reunification efforts and interfere with Chinese sovereignty. (IHT 24 and 27/28-05-95)

On 26 May China cancelled a trip to the US by its defence minister. Earlier it cancelled a visit by a member of the State Council and cut short a visit by the air force commander. (IHT 27/28-05-95) On 28 May it suspended talks with the US on the control of missile technology and cooperation on nuclear energy, and put off a projected visit to China by the director of the US Arms Control and Disarmament Agency. This marked a setback for slowly warming military ties which had been the closest area of cooperation for the two countries. (IHT 29-05-95) China also recalled its ambassador in the US and announced that he would not return to his post for the time being. The Foreign ministry spokesman said: "The basis of bilateral relations has been shaken. This is no trivial matter". (IHT 22-06-95)

Trying to patch up its relations with China, the US reaffirmed its policy of recognizing only 'one China' (IHT 14-06-95) and proposed high-level talks to salvage the deteriorating ties. This was rejected by China on grounds that "[t]o this day, the US side has not taken any concrete moves to eliminate the pernicious effect created by LEE TENG-HUI's US visit". (IHT 23-06-95)

\section{Japan - South East Asia}

When in Singapore during his tour to the Philippines, Vietnam, Malaysia and Singapore the Japanese prime minister laid a wreath at the Memorial to the Civilian Victims of the Japanese Occupation and thus became the first Japanese leader to honour Singaporeans killed during the Japanese occupation.

In Malaysia he was told by the Malaysian prime minister that Japan should stop apologizing for World War II and start act as a world leader in keeping the peace. The Malaysian prime minister also rejected calls for compensation from Japan for events that occurred during the war." If you start seeking compensation for things that happened 50 years ago, what about 100 years ago or 200 years ago? It could turn into demands for compensation from colonial powers." (IHT 29-08-94)

On ending his four-nation tour the Japanese prime minister pledged to expand ties with Japan's Asian neighbours and renounced ever again threatening them militarily. He acknowledged that Japan's aggression had caused "unbearable suffering and sorrow to many people in the region." (IHT 30-08, 01-09-94) 


\section{Japan - Asia}

It was reported that Japan was being attacked by East Asian states for failing to earn their trust and thus being accepted as a representative of the region. For example, it was being reproached by Malaysia for refusing to join other East Asian countries in the East Asian Economic Caucus which was strongly opposed by the US and Australia. The Malaysian prime minister said: "The only Asian country with the ability to help fellow Asian countries refuses to do so but instead demands to know why America is not included." And on 8 November 1994 the Malaysian international trade and industry minister said: "We just need a straight answer from Japan. Does Japan want to be a member of East Asia? If it doesn't, it should say so." And at the meeting of the UN General Assembly in October 1994 not a single Asian country expressed support for Japan's bid to become a permanent member of the UN Security Council. (IHT 10-1194)

\section{Thailand - US}

Thailand requested the renegotiation of a 28-year-old 1967 Treaty of Amity which dealt exclusively with economic matters. Under the treaty US companies are granted equal rights to Thai companies and the right to $100 \%$ ownership of their Thai subsidiaries. These privileges are not accorded to other foreign companies. Fiduciary functions are exempted from the privilege.

Early April 1995 the government was advised to bar the US-owned Universal Insurance from establishing full branches in Thailand because the firm is almost entirely foreign-owned, while a 1992 insurance law restricts foreign ownership in the sector to $25 \%$. There was US suspicion that the case might be used to push for renegotiation of the 1967 treaty. (FEER 19-01-95 p. 20; 04-05-95 p. 72)

\section{North Korea - US}

(see also: Border incidents at p. 395)

In the talks on the elaboration of the August agreement in principle (see infra $\mathrm{p}$. 471), the two countries also dealt with the establishment of liaison offices in each other's capitals. (IHT 14-09-94; FEER 29-09-94 p. 22)

There was a great deal of mistrust between the parties (IHT 15-09-94) and at one time the US deployed an aircraft carrier group off the Korean coast, comprising an aircraft carrier, three cruisers, a frigate and two logistics ships by way of sending "a very strong message" and to influence the current diplomatic efforts. (IHT 23-09-94) The naval exercises were denounced by North Korea as a 'war gamble' that could complicate negotiations. (IHT 24/25-09-94)

A Framework Agreement was reached by the two states and signed in Geneva on 21 October (see: Selected Documents), providing for a three-phase plan, whereby nuclear dismantling would proceed step by step with reactor replacement, giving both sides leverage against reneging. (see also: Nuclear capability at p. 471)

Under the agreement North Korea would freeze its nuclear reprocessing program, meaning not refuelling, and shutting down, a five-megawatt graphite reactor, and 
stopping the construction of two 50-megawatt and 200-megawatt plants, resulting in a complete dismantling of the program in about ten years. The agreement also provided for a resumption of international inspections of the North Korean nuclear installations.

In exchange the US would arrange for its allies to provide North Korea with two modern, 1,000 megawatt light-water nuclear reactors worth around $\$ 4$ billion. The reactors would operate on imported uranium, facilitating some control over the North Korean nuclear program. The US would also provide for interim energy supply for North Korea until the reactors would be completed, which would take at least five years.

At the end of stage one, with construction of the first light-water reactor well under way but before key nuclear components have been supplied, North Korea would allow international inspection of the two installations suspected of harboring nuclear wastes from plutonium production.

In stage two, as construction proceeds on the two new reactors, North Korea would allow the estimated 8,000 plutonium-laden spent fuel rods which were removed from its research reactor in May 1994 to be transferred to another country.

In stage three, as the second replacement reactor nears completion, North Korea would dismantle all its old graphite reactors and reprocessing plant. This dismantling of nuclear installations is more than the NPT requires.

Also under the agreement the two countries would exchange diplomatic liaison offices and there would be a resumption of the North-South dialogue. The agreement also contained a US pledge not to use nuclear weapons against North Korea. (IHT 19, $20,21,22 / 23,26$ and 28-10-94, 03-11-94)

In a letter of 26 October 1994 to the North Korean leader the US president committed himself "to use the full powers of my office" to provide the light-water reactors for North Korea if the project would not be completed beyond the control of the latter. (IHT 27-10-94)

North Korea declared on 1 November 1994 that it had stopped the building of two nuclear reactors and shut down the 5-megawatt reactor. On the other hand South Korea and the US started their annual 'Foal Eagle' military exercise (but not the 'Team Spirit' exercise which would involve the participation of US forces which are not normally stationed in South Korea), giving cause to a North Korean response that it would hinder the carrying out of the accord. (02-11-94)

On 9 January 1995 North Korea announced it would lift restrictions on trade and financial transactions with the US as part of the framework agreement. The decision would also allow the entry of US ships into North-Korean ports and the opening of telecommunications services between the two countries. (IHT 10-01-95)

\section{South Korea - US}

The South Korean foreign minister visited the US early September 1994 to convey South Korean worries about increasing US contacts with North Korea which might diminish the effects of the US-South Korean alliance. It was expected that the South Korean emissary would emphasize two issues:(1) opening liaison offices in Washington and Pyongyang and any improvement in the US-North Korean relations must be done in parallel with improvements in relations between South and North Korea; (2) persua- 
de the US not to sign a peace treaty with North Korea with the exclusion of South Korea. (IHT 07-09-94)

\section{China - Russia}

The Chinese president arrived in Russia for a visit and talks on 2 September 1994. It was the first visit by a Chinese president in 37 years. A Declaration was signed at the end of the talks. In it the two countries agreed not to aim nuclear missiles at each other, never to use force against each other, and to sharply limit the number of troops stationed along their border. Each would also stay out of organizations that threatened the other and would prevent ideology from obstructing bilateral relations. The two presidents also signed economic agreements and an accord on the western section of the 4,400-kilometre Sino-Russian border. (IHT 3/4 and 05-09-94, BR 12/18-09-94 p. 18; FEER 15-09-94 p. 13)

\section{Iran - France}

The President of Iran in an interview published on 12 September 1992 urged France to withdraw its support of the Algerian government. He said that the French backing could be compared to the US support of the late shah in Iran. (IHT 13-09-94)

\section{Vietnam - Eastern Europe}

Vietnam started to re-establish economic relationships with Eastern Europe. In August 1994 agreements on investment promotion and protection were signed with Hungary, Romania and Poland, on avoidance of double taxation with Hungary and Poland, and on trade with the Czech Republic. (IHT 24/25-09-94)

\section{South Korea - Japan}

A meeting of delegates from China, Russia, Japan and South Korea in Seoul in September 1994 to discuss a plan for pollution control in the above sea (Northwest Pacific Action Plan) met with difficulties when the South Korean media protested against the use of the term 'Sea of Japan' when referring to the sea concerned. While the sea is known in Japan as Nihon Kai or Sea of Japan, it is referred to in Korea as the Tonghae or the East Sea. In the end it was agreed to describe the affected waters only by their latitude and longitude. (IHT 26-09-94)

\section{Iran - Iraq}

The deputy head of the foreign affairs sub-committee of the Iranian parliament said that Iran has a strategic interest in having Iraq re-emerge as a regional power. (IHT 0410-94) 


\section{India - Pakistan}

News reports referred to an Indian six-point memorandum put to Pakistan in January 1994. Five of the points were proposals to stabilize territorial flashpoints and the like. One contained nuclear security proposals: no first use of nuclear 'capability' and agreement not to target population centres with nuclear weapons in any conflict. Pakistan rejected the memorandum on ground that it did not address central issues such as the future of Kashmir, and because the nuclear proposals were exactly what a conventionally superior power would propose to a weaker one to remove the latter's main means of deterrent. (FEER 06-10-94 p. 18)

In the Indo-Pakistan conflict each side accuses the other side's intelligence service's role in destabilizing the opposite party. Indian intelligence officials charge that the (Pakistan) Inter-Services Intelligence (ISI) agency had been channelling funds to the National Socialist Council of Nagaland in northeast India through Bangladesh, and that the ISI was running training camps for Indian rebels in a number of locations in Bangladesh. Pakistan denied this, but officials acknowledged privately that the ISI was active in Kashmir. (FEER 20-10-94 p. 34)

\section{China - Israel}

The Chinese vice-prime minister paid a four-day visit to Israel. He was the highestranking Chinese official to visit Israel since the two countries established diplomatic relations in 1992. (FEER 13-10-94 p. 13)

\section{Asia - Europe}

The European Commission on 13 July 1994 called for a radical overhaul of economic and political relations with Asia to avoid being sidelined. These relations had been strained over linkages made between trade and aid to human rights and labour and environmental standards. The Commission said it was urging businesses and governments in the EU member countries to mobilize their forces to open markets, increase investment opportunities for European companies and involve Asia more closely in international economic institutions. (IHT 14-07-94)

The significant change in policy also appeared during the annual meeting with ASEAN when a new approach to Myanmar was outlined, shifting the European position away from ostracism and closer to the ASEAN policy of constructive engagement. The president of the European Council of Ministers said that Europe was prepared to follow ASEAN's lead and hold talks with the Myanmar military on ending repression and restoring democratic rule. (IHT 27-07-94)

With regard to the possible emergence of an American-Asian trade alliance in APEC the EU initially took a negative attitude but later had no objections provided Asia would remain committed to a policy of 'open regionalism', extending trade concessions within APEC to others without discrimination.

A meeting of EU and ASEAN foreign ministers took place in Kalsruhe on 24-25 September 1994. The meeting resulted in a 'Karlsruhe Declaration', highlighting 
ASEAN's claim of being a 'gateway' to the Asia-Pacific region and describing EuroASEAN cooperation as a "central element in relations between Europe and the AsiaPacific".

The EU discarded its earlier confrontational approach in dealing with the region but trade relations were likely to remain difficult. Among other things, the European Commission had proposed to terminate tariff concessions for Singapore, Brunei, Thailand, Indonesia and Malaysia, and had threatened to impose anti-dumping duties. The EU appeared reluctant to open the European markets in 1995 for Asian textiles despite commitments to phasing out textile import quotas in the Uruguay Round: from 1995 importing countries would be obliged to phase out quotas on $16 \%$ of their textile and clothing imports. This would be the first stage of a decade-long, four-stage phaseout of the Multifibre Arrangement (MFA). Being free to choose the categories of goods to liberalize at each stage, the EU planned to select items which are already exempt from MFA quotas for the first round of liberalization. The EU was also pressing for international discussions on introducing a 'labour clause' within the World Trade Organization, thus facilitating the EU and the US to shut out competitive Asian exports. Besides, Japanese requests for a bigger quota for their car exports to Europe were turned down. (FEER 06-10-94 p. 15; 13-10-94 p. 72)

In October 1994 the World Economic Forum organized a meeting of Asian and European political and business leaders at Singapore, after a first such meeting in Hong Kong in 1993. The meeting agreed on a wide-ranging program to build closer relations. The proposals included a call for regular gatherings of East Asian and European heads of government similar to the informal summit meetings of leaders from the APEC countries. Besides there were far-reaching proposals on trade and investment liberalization. The proposals said it was essential that European countries make a commitment to control the spreading use of anti-dumping measures.

During the meeting the Malaysian prime minister said that before a genuine partnership of equals could be built with East Asia most of Europe had to get rid of an attitude that "some will call incredible arrogance". Reflecting resentment among many East Asian governments at attempts by the EU to link human rights standards to trade or aid, he said that no Asian country had demanded that European states reform themselves. A former French prime minister found the statement unacceptable and said that Asian descriptions of the European Union as a highly protected fortress were belied by East Asia's large and growing trade surplus with Europe. (IHT 14 and 15/16-10-94)

The idea for a Euro-Asian summit meeting was advanced for the first time by the Prime Minister of Singapore on a visit to France in October 1994. (IHT 09-12-94) At a meeting in Singapore of senior officials of the EU and ASEAN it was agreed on 4 May 1995 to hold an East Asia-Europe summit meeting in Thailand in early 1996.

Meanwhile European leaders at a meeting at Essen, Germany, in December 1994, had endorsed a new strategy for dealing with Asia. IHT 05-05-95)

\section{South Korea - China}

Early November 1994 the Chinese prime minister, the highest-ranking Chinese official so far, visited South Korea. The two states concluded three agreements: on 
direct air links and on a joint-venture airplane project, and a memorandum of understanding on cooperation in nuclear power generation. (IHT 01-11-94)

\section{Vietnam - Cambodia}

Cambodia accused Vietnam of preventing Phnom Penh-bound cargo ships from proceeding up the Mekong River, in violation of international law. The blockade might be in retaliation of a new Cambodian immigration law which could be the basis for the expulsion of ethnic Vietnamese. (FEER 17-11-94 p. 13) (see: Minorities at p. 470)

\section{Japan - Israel}

On the occasion of the first visit of the Israeli Prime Minister to Japan in December 1994 agreements were signed on expanding cultural and scientific exchanges.

Japan long observed the Arab boycott on Israel, but had become receptive to investment and trade recently. The first Japanese economic mission to Israel was sent in August 1993. (IHT 13-12-94)

\section{Thailand - Myanmar}

An initiative of 1988 led to the decision to build a bridge across the Moei River which separates Thai and Myanmar territory. The bridge reflected a significant warming in Thai-Myanmar relations and highlights Thailand's policy of 'constructive engagement' with Myanmar.

A memorandum of understanding to build the bridge was signed in January 1990 and the bridge would be completed some time in 1996. (FEER 03-11-94 p. 16)

\section{China - Myanmar - India}

Cross-border trade between Yunnan Province and Myanmar had swollen in the last ten years from about $\$ 15$ million annually to around $\$ 800$ million.

Out of concern for China being allowed to carry out monitoring activities along the Myanmar Indian Ocean coast, India made several diplomatic representations to Myanmar in 1993 and 1994.

In August 1994 Indian coastguards intercepted what appeared to be a Chinese survey vessel that had strayed into Indian waters near the Andaman islands. At the same time three fishing vessels with Chinese crew were also detained at Port Blair on the Andamans, but were later released. (FEER 22-12-94 p. 23)

The Chinese prime minister paid a visit to Myanmar in late December, being the fourth foreign head of government to visit Myanmar since the introduction of military rule in 1988. Among the topics of discussion were border and economic issues. (IHT 27 and 28-12-94) 


\section{Iran - Norway}

Following the recall of the Iranian ambassador to Norway (see infra: Jurisdiction), Norway downgraded its diplomatic relations with Iran by way of protest against the death edict on the author SALMAN RUSHDIE. The Norwegian ambassador to Iran who was recalled for consultations on 16 January 1995 would remain in Oslo "for an indefinite period". (IHT 01-02-95)

Iran responded by threatening Norway with an economic boycott by "fully implement[ing] the economic restrictions it introduced several months ago" unless Norway would refrain from 'anti-Islamic' policies. (IHT 03-02-95)

\section{Iran - Sweden and Denmark}

Sweden cancelled its invitation to an Iranian deputy foreign minister who was on a tour of Scandinavia, under pressure of Norway. (see supra) The minister's visit to Denmark, however, would take place as planned. (IHT 4/5-02-95)

\section{China/Thailand - Laos}

China established full diplomatic relations with Laos in 1987 after the waning of Vietnamese and Russian influence, and since then Chinese aid and influence had been increasing regularly. Laos, with a population of 4.4 million, is attractive for China as a land bridge between China and Thailand and as a gateway to Southeast Asia generally. However, Thailand remained the most important economic partner of Laos, accounting for more than half of its imports and exports, while China only buys $5 \%$ of Laotian exports and supplies only $11 \%$ of its imports. (FEER 09-02-95 p. 18)

\section{Intra-Asian diplomatic contacts}

Asian diplomats in Washington, D.C. had begun bi-monthly informal meetings to discuss matters of common interest. ASEAN diplomats had been meeting regularly for several years, but meetings were now taking place on a wider, regional, basis. (FEER 16-02-95 p. 12)

\section{Japan - North Korea}

The three governing parties of Japan and the (North) Korean Workers' Party signed a declaration on 30 March 1995 urging their governments to revive efforts to normalize diplomatic relations.

Japan and North Korea began talks on normalizing relations in early 1991 but the talks broke down after the eighth round in late 1992, when North Korea rejected a Japanese demand for information about a Japanese woman allegedly abducted by North Korean agents. (IHT 31-03-95) 


\section{Nepal - India}

The Nepalese prime minister on 11 April 1995 pressed India to change a treaty between the two countries that, inter alia, prohibited arms deals by Nepal with other countries. He demanded the right to import arms from China, as "it is the right of every country to import arms which are cheaper". (IHT 12-04-95)

\section{Vietnam - South Korea}

The leader of the Vietnamese Communist Party paid his first visit to South Korea and took the opportunity to call for closer ties between the two countries. Three years after establishing diplomatic relations, South Korea had become Vietnam's third-largest trading partner and investor. (IHT 13-04-95)

\section{Japan - Iran}

It was reported that Japan had delayed a $\$ 500$ million loan to Iran because it was opposed by the US. (IHT 14-04-95)

\section{Iran - India}

The president of Iran paid a state visit to India in April 1995, being the first trip by an Iranian head of state to India since the 1979 revolution. (IHT 18-04-95) On this occasion Iranian officials called for a "regional axis of China, India and Iran to combat Western hegemonism". The Iranian president signed a tripartite agreement with India and Turkmenistan, giving India access to trade through the Iranian port of Bandar Abbas that has a rail link with Ashkhabad. This gave India direct access to Central Asia, bypassing Pakistan and Afghanistan. (FEER 15-06-95 p. 32)

\section{China - Czech Republic}

China refused to sign a student-exchange agreement to protest the visit of the Taiwanese prime minister to the Czech Republic. The latter was granted a meeting with the Czech president on 21 June 1995. (IHT 21 and 22-06-95)

\section{Sri Lanka - South Korea}

It was reported that Sri Lanka withdrew its candidature for the Asian seat on the UN Security Council in favour of South Korea, allegedly in exchange of a substantial infusion of aid and investment from the latter and the prospect of 10,000 jobs for Sri Lankans in South Korea. (FEER 08-06-95 p. 27) 


\section{Sri Lanka - Israel}

Sri Lanka decided to restore diplomatic relations with Israel after breaking them off in 1990, apparently because of its heavy dependence on Arab oil. The relations were previously severed in 1970 to be restored in 1984. (FEER 08-06-95 p. 27)

(NON-)INTERFERENCE

(see also: Inter-state relations: general aspects, at p. 438; Iraq-Kuwait War)

\section{Chinese accusation of US interference}

China on 2 February 1995 accused the US of using "the excuse of human rights" to meddle in China's internal affairs. The statement was in response to the annual report on human rights violations by the US State Department, in which China was described as an authoritarian state with a record of "wide-spread and well-documented human rights abuses". (IHT 03-02-95)

\section{INTERNATIONAL CRIMINAL LAW}

\section{Japanese comments on the ILC-draft statute for an international criminal court}

Early November 1994 the Japanese government submitted its comments on the draft statute. As a whole Japan found the draft inadequate in terms of substantive as well as procedural law. There should be a better adjustment and coordination of the draft statute and the Draft Code of Crimes against the Peace and Security of Mankind.

With regard to the substantive law great emphasis is laid on the principle of nullum crimen sine lege, which implies a precise determination, by written rules, of the constituent elements of the crimes falling under the jurisdiction of the Court, the punishments to be imposed, the factors which constitute a defence, and the factors for aggravating or mitigating a sentence.

Under these criteria Art. 20 of the draft statute is considered inadequate. As to genocide under the Genocide Convention it is said that the definition in that convention does not provide unequivocally nor precisely the constituent elements of the crime either. The same applies to Art. 33 which includes national law among the laws to be applied without elaborating which national law is referred to, nor in what cases it should take place.

With regard to penalties the comments consider it imperative that statutory penalties be fixed for each crime. Art. 4 of the draft statute does not fulfill these requirements, and the reference to penalties provided for by the national law of the state involved suffers of the same deficiencies as in Art. 33.

Because of the international character of the court and the particularly serious character of the crimes involved, resulting in the expected pressure of world opinion to exact punishment, there should be stipulated very strict safeguards to ensure a fair and impartial trial. Yet the provisions of the draft statute concerning the investigative 
and trial procedures, rules of evidence, appeal, review and execution of sentences, etc. are most elementary and inadequate. Inter alia, the issue of subpoenas and warrants for the purpose of gathering evidence should be regulated in the statute itself instead of simply empowering the Presidency to take such compulsory measures, as provided in Art. 26 of the draft statute.

Generally, Japan is of the opinion that the procedures to be followed by the court should be regulated in detail in the statute itself (i.e. by treaty) instead of in the Rules of the Court. While it is true that under Art. 19 of the draft statute the initial Rules of the Court and 'important amendments' of the rules are to be submitted to a conference of states parties for approval, yet the draft statute does not provide for the procedure for approval and, moreover, the procedure for the amendment of rules which the Court does not consider important is also inadequate.

The Japanese comments also contained critical remarks on, inter alia, the provisions concerning obligatory transfer of criminal jurisdiction by a state to the Court which may conflict with constitutional provisions on exercise of jurisdiction, the mandatory application of an absolute prohibition of double jeopardy, and the rule of "aut dedere aut punire". (UN doc. A/C.6/49/3 of 10-11-94)

\section{INTERNATIONAL MONETARY FUND}

\section{North-South conflict on creation of SDRs}

During the annual IMF-World Bank meeting in October 1994 a sharp conflict arose over the proposal made by the IMF managing director to create over $\$ 50$ billion of Special Drawing Rights. The G-7 states (US, Canada, UK, Germany, France, Italy and Japan) rejected the idea on grounds that with the growth of global capital markets, the developing countries no longer needed to rely on a big expansion of SDRs. A USBritish compromise proposal would allow the IMF to create $\$ 23.4$ billion of SDRs which would be allotted mostly to the Eastern European countries. This was voted down by the opposing bloc of developing states, resulting in no creation of SDRs at all. It was the first time since the North-South polemics of the 1970s that the poorer states were able to block the wishes of the developed states. (IHT 03 and 04-10-94)

\section{Consequences of increased economic power of Asian states}

When the IMF endeavoured to set up a $\$ 50$ billion package to bail out Mexico it turned, for the first time, also to some Asian states with reserves totalling at least four months of imports. These requests are likely to occur more often in the future and the question was that in return they would have to be offered a greater say in running the Fund.

One way would be by raising the region's share of the Fund's capital and thus its voting rights. At present South Korea, China, Singapore, Malaysia and Thailand hold a mere $4.1 \%$ of the total votes, and India and Indonesia $3.1 \%$. It took Japan and Germany eight years to increase their share in 1992. 
Another way would be to increase the number of countries that participate in the $\$ 29.4$ billion General Arrangements to Borrow, a pool of pledged money that can be drawn upon in times of crisis. So far only the G-10 plus Switzerland and Saudi Arabia take part in the arrangement. (FEER 04-05-95 p. 61)

\section{INTERNATIONAL TRADE}

(see also:) Inter-state relations: general aspects

\section{US fruit imports in China}

After two years of negotiations since May 1992 an agreement was reached in June 1994, ending a Chinese ban on American fruit and allowing the import of apples from Washington state. The Chinese quarantine law of 1992 bans fruit from 73 countries considered to be a 'medfly' risk. (IHT 16/17-07-94)

\section{US quota on textile imports from China}

The US slashed its quota on Chinese textile imports as of 1 July 1994 in retaliation for an estimated $\$ 2$ billion of Chinese textiles allegedly incorrectly labeled as originating from elsewhere. China protested against the measures, qualifying them as a violation of an agreement reached in January 1994 (see 4 AsYIL 473). According to US figures Chinese textile and clothing imports to the US in 1993 was valued $\$ 7.2$ billion. In May 1995 another cut in quotas was announced (IHT 23/24-07-94; FEER 18-05-95 p. 99)

Apart from genuine imports from China, Chinese factories also do preliminary stitching on much of the clothing imported from Hong Kong, Singapore and other Asian countries. The US apparel industry wanted to have these garments be counted against the Chinese quota. Since the mid-1980s a series of customs decisions held that a garment's origin was based on where its fabric was cut. Before that, the origin was based on where a garment was sewn and assembled. Since then labour rates had risen in places like Hong Kong, so that fabrics were cut there employing high-speed laser technology, for assembly in China. This caused the US clothing industry to demand to change the rule back to the 'sewing and assembly' standard. (see infra, p. 451) (IHT 13/14-08-94)

\section{Japanese-US trade dispute}

The framework agreement reached in July 1993 (4 AsYIL 468) provided for negotiations on a variety of sectors of trade. Yet during the following year no single deal was concluded on any of the five Japanese markets: automobiles, auto parts, insurance, and government procurement of telecommunications and medical equipment. A deadline was repeatedly moved back, accompanied by US threats of trade sanctions if no results were reached. At the end of July 1994 the US threatened to impose trade sanctions if there was no agreement by the end of September. The 60-day "consultation and negotiation period" was authorized under US trade laws. 
The failure of the negotiations so far had resulted in an appreciation of the yen, on the one hand reducing the Japanese trade surplus by pricing the Japanese goods out of the markets, but on the other hand leaving the Japanese investors unwilling to make new investments. The reaching of a trade agreement was widely seen as a means to depreciate the yen, leading to sale of yen and new investments abroad.

There were in fact two issues: first, how to ensure improved market access for American telecoms and medical-equipmentsuppliers; second, how to measure the result of the changes.

Telecommunications and medical technology were among the priority areas mentioned in the 1993 framework agreement. The US argued that the foreign share of Japan's public and private telecoms market was currently $5 \%$ compared with a foreign share of $25 \%$ of the markets of other rich countries. In the case of medical equipment, US manufacturers accounted for nearly $40 \%$ of the market in the EU, but less than half that in the Japanese market. According to the Japanese, however, the foreign share of the US market for officially procured telecoms and medical equipment is even smaller $(0.07 \%)$ than it was in Japan $(0.6 \%)$. By contrast, foreign firms accounted for a $38.5 \%$ slice of Japanese government purchases of medical equipment in 1991, against 1.5\% in the US.

The US was insisting on quantitative and qualitative benchmarks while the Japanese side dismissed such proposals as amounting to managed trade. Since the 1970s Japan and the US had negotiated 12 bilateral trade agreements on government procurement but results were said to have been minimal. (IHT 25-07, 01-08 and 29-08-94; FEER 11-08-94 p. 69)

On 13 September the Japanese side emphasized that "there are no prospects" for agreement on all aspects of the dispute by the deadline. The insurance sector where the US had not made demands for objective indicators was likely to be the first sector in which an agreement could be reached. (IHT 14-09-94)

On 1 October the two sides reached agreement in principle on opening the Japanese market in three sectors: government procurement of telecommunications and medical equipment, insurance (34 ILM 661), and flat glass. Final agreement on Japanese imports of flat-glass was reached on 12 December 1994. No numerical targets were set but a variety of objective criteria would be used to assess improvements in market access and foreign efforts made. A multi-tiered formula was used to evaluate whether there has been 'a significant increase' in access of foreign products and services. The agreement did not include any means to enforce, should penetration of the Japanese market not significantly increase.

No agreement was reached in the field of automobiles and motorcar-parts. As a result the US listed Japan under section 301 of its trade law (see 2 AsYIL 334, 4 AsYIL 469), beginning a process that could result in sanctions within 12 months. (IHT 03-10-94, 13-12-94; FEER 13-10-94 p. 18) The only operative agreement between the two countries regarding automobiles dated from 1992, when Japan pledged to buy $\$ 19$ billion worth of US auto-parts over a period ending 31 March 1995. (see 2 AsYIL 337) (IHT 18/19-03-95)

The negotiations on motorcars were resumed on 27 March 1995 with the US seeking agreement in three areas: providing more dealerships for US cars, boosting purchases of US-made parts (for new cars), and expanding sales of US replacement 
parts by a relaxation of inspection regulations. (IHT 25/26-03-95) The US demanded that Japanese carmakers renew and increase so-called 'voluntary plans' for increased purchases as made in 1992.

Japan agreed to reassure Japanese car dealers that they are free to sell competing automobiles but refused to oblige Japanese car manufacturers to allow their dealers to sell competing foreign cars. Japan also denied the US allegation that the share of foreign cars in the Japanese car market is abnormally small, referring to the fact that the market share of European cars in Japan was larger than in the US. At the market for cars with engines larger than $2,000 \mathrm{cc} 28 \%$ consists of imported cars, although it was admitted that only $20 \%$ of the cars sold in Japan belonged to this category.

As to components, accounting for $80 \%$ of the value of worldwide car sales, foreign car-parts took only $2.6 \%$ of the Japanese market, compared with $32.5 \%$ of the US market in 1994. However, purchases by Japanese car manufacturers of (foreign made) components rose from $\$ 2.5$ billion in 1986 to $\$ 20$ billion in 1994, although more than $90 \%$ of it concerned purchases by Japanese car plants in the US.

Finally, with regard to replacement parts, most vehicle inspections in Japan are performed at government-designated garages which are usually tied to Japanese manufacturers and accordingly use their parts. Japan refused to have inspections performed by more garages because of safety reasons.

As the positions of the two sides remained far apart, the Japanese trade officials threatened that if the US would impose trade sanctions, Japan would appeal to the WTO. (IHT 31-03-95) While the Japanese accused the US of trying to force them to accept numerical targets for US exports, the US contended that Japan's system of closed markets and its huge $\$ 66$ billion trade surplus with the US had to be resolved. Automobiles and car parts make up nearly 60 percent of the US trade deficit with Japan. (IHT 6/7-05-95; FEER 18-05-95 p. 97)

It was reported that while US officials conceded that unilateral tariffs would violate WTO rules, the US was preparing a counter-complaint in case Japan would take action at the WTO. The counter-complaint would allege that excess regulation and collusion among Japanese car manufacturers discriminate against the sale of foreign-made cars and car-parts. The complaint would rely on the WTO "nullification and impairment" clause. It would argue that anti-competitive features of Japan's domestic market essentially have 'nullified' the benefits of the tariff reductions to which Japan committed itself by joining the trade organization and the former GATT.

[The nullification and impairment argument was used by the US under the GATT to overturn European soybean subsidies, and invoked by the EU in 1983 to challenge collusion in the Japanese car industry] (IHT 10-05 and 13/14-05-95) As to the alleged illegality of unilateral recourse to sanctions the US Trade Representative said that there was agreement "that we'd all use the WTO's dispute settlement mechanism, but for those items not covered we'd preserve our own trade laws". (IHT 22-05-95)

According to news reports a few days later it was expected that the dispute would be settled by direct concessions from Japanese car companies rather than from the Japanese government. These concessions could consist of increasing imports of carparts produced by Japanese subsidiaries in the US. (IHT 13/14-05-95)

A target list of Japanese luxury cars for US punitive sanctions was issued on 16 May 1995, which would nearly double their prices. The sanctions would not take effect 
before the lapse of a 30-day comment period. The tariffs would wipe out Japanese exports to the US of luxury cars, but would comprise less than 2.2 percent of the value of total worldwide Japanese exports. (IHT 17-05-95) The intended US sanctions were criticized by the EU as being illegal because it would be discriminatory action in breach of the most-favoured nation obligation.

On 17 May Japan asked the US for consultations in accordance with WTO rules to try to solve the dispute, qualifying it "a case of urgency" so that it could demand a WTO panel to be established within 20 days after seeking consultations, instead of the 60 days for normal disputes. The US agreed to the consultations but rejected the urgency classification, proposing the talks to be held in the second half of June 1995. (IHT 18 and 27/28-05-95)

The EU warned that it would bring a complaint to the WTO if the US secured a car deal with Japan that was discriminatory to European manufacturers (IHT 25-05-95), and on 31 May 1995 the EU formally asked to be included in the upcoming consultations between the US and Japan, claiming it had "a substantial trade interest" in strict observance of the WTO regulations. (IHT 01-06-95) The EU request was rejected by the US. (IHT 08-06-95)

In June it was reported that there were signs of both countries edging toward a breakthrough as a Japanese newspaper reported that Toyota was preparing to increase the percentage of locally made car-parts to be used at its US factories. All publicly discussed proposals were similarly focused on increases in the 'local content' of cars made in Japanese factories in the US. Acceptance of such plans by the US would imply a withdrawal of its primary objectives, viz. the purchase of more American parts for cars made in Japan. One major question was whether the [Japanese] ministry of international trade and industry (MITI) would stop Japanese companies from issuing parts-purchasing plans because the US tended to view such plans previously as binding targets.

The US Undersecretary for International Trade said on 21 June 1995 that if the Japanese government was not prepared to meet US demands, the US was ready to accept remedial actions on the part of individual Japanese companies. He also emphasized that the US was not seeking to impose numerical quotas on Japanese imports. (IHT 22-06-95)

On 28 June 1995 the two sides reached agreement. The Japanese minister for international trade and industry said that Japan had been able to 'maintain its basic principles', i.e. its opposition to fixed numerical targets for foreign cars and car parts imports into Japan. As soon as the accord was reached major motor manufacturers in Japan announced 'voluntary' plans to increase production and investment in the US and use more US spare parts in vehicles assembled in the US. According to the agreement the plans "are not commitments and are not subject to the trade remedy laws of either country." Similar targets were also set on access for US cars to Japanese car dealerships. With regard to access for foreign car parts manufacturers to the Japanese repair market Japan merely agreed to further deregulate its car repair sector. All these plans and intentions made economic sense against the backdrop of the surge of the yen against the dollar.

Immediately after its conclusion the agreement became the object of contradictory interpretations. In view of the failure in getting Japan agree to binding numerical 
targets, the US started unilaterally to set figures which were alleged to be consequential to the agreement and, at least partly, extrapolated from it. (IHT 29 and 30-06-95)

\section{Japanese-US semiconductor trade agreement}

The two parties agreed to continue the existing agreement (1 AsYIL 321) for its full five-year term, ending in July 1996. Although Japan contends that the agreement goes no further than noting the US industry's 'expectation' that foreign share of the Japanese market would exceed 20 percent, there was Japanese criticism that the agreement virtually guaranteed foreign producers a share of the domestic market, and there were calls from Japanese producers to end the agreement. (IHT 28-07-94)

\section{Automobile import in Korea}

Although South Korea recently removed a number of legal barriers to foreign cars, Western producers kept complaining about the difficulties they had to overcome to penetrate the market. According to them, similar to the Japanese market the problem was not so much formal barriers but rather non-tariff barriers, such as perceived pressure to 'buy Korean' and dealer networks controlled by South Korean car producers.

In June 1994 the government announced a plan to improve the access by Western companies. Tariffs would be cut from 10 to 8 percent, and a surtax on luxury cars would be abolished. Restrictions on floor space at sales outlets would be eliminated and Western car producers would be permitted to advertise on television during prime time. Yet the measures were dismissed as inadequate by the Western companies. The bigger problem was said to be the fact that distribution of Western cars took place through independent dealerships which are small and scarce, in contradistinction to Korean car companies which own wide-spread dealer networks. (IHT 20/21-08-94)

In May 1995 South Korea was reported to be preparing an overhaul of its trade regulations out of concern that the US trade dispute with Japan would lead to increased efforts by the US to pry open the South Korean automobile market. (IHT 13/14-05-95)

\section{China - Japan}

Japan considered measures to control imports of Chinese textiles that undercut domestic producers. China denounced the Japanese plans, warning that the move would harm trade ties and that China would be forced to retaliate since the textile exports were an important device to balance its large trade deficit with Japan. Japan-China trade was worth $\$ 20$ billion in the first half of 1994 , and the forecast for the whole year was $\$ 45$ billion to $\$ 50$ billion. It was not clear how much of the exported textiles were made by Japanese companies operating in China. (IHT 30-09-94)

\section{EC anti-dumping duties on Asian TV sets}

The European Commission on 30 September announced the imposition of antidumping duties on TV sets made in Malaysia, China, Korea, Thailand and Singapore, 
ranging from 5 to 30 percent. The Commission was responding to a complaint made two years ago by European manufacturers. The market share of the five Asian countries increased from 9.9 to 19.6 percent in 1991-1992 while the European industry share declined from 36 to 28 percent. Units of Thomson and Philips would be among the Asian companies to suffer from the measure. (IHT 01/02-10-94)

\section{Annual quota of Japanese car imports in Europe}

(see: 1 AsYIL 322; 3 AsYIL 408; 4 AsYIL 470)

Japan and the EU reached agreement on an increase of Japanese car imports into the European Union for the year 1994, under a 1991 agreement on the matter. The estimated increase in European car demand for 1994 was 4.4 percent, but the Japanese were allowed a 1.3 percent increase. (IHT 1/2-10- 94) Yet, the European Automobile Manufacturers Association complained about the agreement because of its mainly political importance while the improvements in sales was not likely to last. (IHT 04-1094)

In February 1995 it was reported that the two parties had as yet been unable to reach agreement on the volume of Japanese car exports to Europe in 1995. They had failed to reach agreement on both the outlook for the European automobile market and whether to include three new EU members, Austria, Sweden and Finland. (IHT 18/1902-95)

On 31 March 1995 agreement was reached on expansion of the Japanese share in the European market by 1.7 percent in 1995 . On a forecast of market growth of 4.3 percent the maximum Japanese share would be 8.3 percent. But like 1994, actual imports were expected to remain well below the theoretical limit because of the eroding competitiveness of Japanese cars. The scope of the accord would be enlarged by including the three new EU members Sweden, Finland and Austria. All three were included in the 'unrestricted' category of 10 countries to which a group allotment applies. (IHT 01/02-04-95)

\section{US world trade implementing legislation}

A number of amendments which were to be introduced in the US law on world trade caused concern with Asian exporters. As to anti-dumping, it would become easier to act. Profit that a company is deemed to have earned on imports from a foreign affiliate would be deducted from the export price; US firms could claim this lower price to amount to dumping, or the selling of goods below 'fair value'. A second area of contention were the country-of-origin rules in the garment trade. The bill proposed that for quota purposes, garment exports to the US would be deemed to originate where they are assembled, not where they are cut - a provision that targets Hong Kong and China. Third, the bill called for the generalized system of preferences to expire on 31 July 1995. Malaysia, Thailand, the Philippines, Indonesia and India would be affected. (FEER 13-10-94 p. 71) 


\section{China - US}

An agreement was signed on 12 March 1995, easing access to China's markets to US products in exchange for increased US support for China's bid to enter the WTO. (IHT 11/12 and 13-03-95) The US concession would consist of recognizing that while for certain purposes China should be considered a developed country, it was to be considered a developing country for other purposes. This would imply that China would be granted extra time before it would be required to phase out certain tariffs and protective trade restrictions. (IHT 15-03-95)

Barely several weeks later the US through its Undersecretary of Commerce for international trade warned China that unless it lowered its trade barriers the US would withdraw its backing for Chinese membership in the WTO. Other means to achieve the goal were applying pressure on China to conclude deals with American companies and barring China from the US market if its products were government-subsidized.China was said to be especially protectionist in the energy, financial services and industrial equipment sectors. (IHT 10-04-95)

\section{US most-favoured nation treatment for China}

The US president on 2 June 1995 renewed most-favoured nation status for China for another year though emphasizing that he still found China's record on human rights unacceptable. Senior US officials said that the only legal criterion left affecting renewal is freedom of emigration. China welcomed the renewal but warned that the time had come for the annual review to be scrapped. (IHT $3 / 4$ and 5-06-95)

\section{Indonesia - US}

It was reported that a shift had taken place in the US policy toward Indonesia. The new relationship was said to fall into a pattern similar to that developed toward China since May 1994: US commercial and strategic interests would be given priority over concerns about democracy and human rights. The US had identified Indonesia, China, India and South Korea as the four 'big emerging markets' in Asia, likely to absorb large amounts of US exports.

Trade between the US and Indonesia amounted to $\$ 8.2$ billion in 1993 , with a large surplus for Indonesia. Cumulative investments in Indonesia since 1967 amounted to only $\$ 8.5$ billion, but these do not include projects in the oil, gas and financial sectors. (IHT 11-11-94)

\section{Japan - Europe}

There was a significant narrowing of the European chronic trade deficit with Japan in 1993 ( $\$ 26.3$ billion) as compared with 1992 (\$31.2 billion), and a continuing decline in 1994.

The EU pushed for more industrial cooperation between European and Japanese manufacturers and tried to persuade Japan to accept mutual recognition of standards for medical and other equipment. The European side also claimed that Japanese importers 
take 'discriminatory' decisions in favour of American goods because they believe their government wants them to concentrate on purchasing American products. (FEER 1108-94 p. 68)

Japan rejected the major European trade demands, such as joining the monitoring process agreed under the Japan-US agreement of October 1994 (see supra) but offered a series of smaller concessions, such as setting up "a system of parallel monitoring". Another demand that was rejected concerned the cutting of the Japanese current-account surplus from the present 3.1 percent to 2.0 percent of gross domestic product in 1995 .

It was said by the European side that the minor agreements had vindicated Europe's non-confrontational or 'persistent but diplomatic' pressure, in contrast to the US 'aggressive and unilateral' approach. (IHT 21-11-94; FEER 29-06-95 p. 70)

\section{Indian textile agreements}

India concluded textile agreements with the European Union and the US on 31 December 1994, significantly increasing or removing import quotas for Indian textiles.

The US and the European Union together buy more than two-thirds of India's textile exports. Textiles account for more than a quarter of India's exports. For its part India would ease its tariffs on certain goods in stages over three to seven years and remove all yarns and fibers from its restricted list of imports. (IHT 03-01-95; FEER $12-01-95$ p. $81 ; 02-02-95$ p. 52)

\section{Dumping of Chinese exports}

The Chinese Ministry of Foreign Trade and Economic Cooperation (MOFTEC) had recorded 37 cases in 1994 in which Chinese exports were investigated or fined in anti-dumping cases. Fifteen of the cases took place in the US, nine in Europe and five in Mexico. (IHT 06-01-95)

\section{India - US}

The US Commerce Secretary, leading a US trade and investment mission to India in January 1995, announced that the mission had concluded deals worth $\$ 5.5$ billion. Contracts worth another $\$ 1.5$ billion were expected to be signed during the last stop of the mission, in Bombay. (IHT 19-01-95)

\section{EU quotas on textile and garment imports from China}

A Sino-EU agreement of 1988 set quotas on Chinese exports of cotton and synthetic textiles as well as clothing. This agreement as well as the existing agreement on silk was modified in order to meet demands from European textile producers for stricter controls. As to the silk accord the EU argued that since China was not a GATT member nor a founding member of the WTO, the EU was entitled to fix unilateral limits on the silk imports. However, the quota set by the EU Commission in 1994 gave rise to serious protests from the European importers and retailers, so that the EU finally agreed to negotiate with China. China acknowledged that a negotiated settlement 
would ensure guaranteed access to the EU market and under a new agreement of 20 January 1995 the EU increased considerably its quota for silk, ramie and linen to 38,000 tonnes, more than double last year's quota. In exchange, China committed itself to take tougher action against international textile fraud such as using bases overseas to avoid the quotas. (FEER 02-02-95 p. 52)

\section{Economic cooperation among Indian Ocean countries}

It was reported that Australia planned calling a meeting of 38 Indian Ocean rim countries to investigate possibilities of expanding trade, investment and economic cooperation. (IHT 21-03-95)

\section{Indonesia - Malaysia}

A historic deal was concluded on 23 February 1995 worth more than RM572 million, involving the purchase by Malaysia of 6 Indonesian-made CN-235 transport aircraft in return for Indonesia's purchase of 1,500 Proton cars and 20 SME MD3-160 high training aircraft. The package also included the servicing and overhaul of Indonesian military aircraft. Indonesia's purchase of the MD3-160 aircraft was the first overseas sale of the Malaysian-made aircraft. Following the historic deal Indonesia agreed to waive the crippling 200 percent duty on completely-built-up units on the Proton cars. The Indonesian government also endorsed the move by Proton to set up an assembly plant in Indonesia within two years. This would be the second such plant for Proton outside Malaysia after the Philippines. Indonesia also offered to help Malaysia to develop its aerospace industry, including on-the-job training for Malaysians. (NST 23 and 24-02-95)

\section{Illegal Afghanistan-Pakistan trade}

(cf. Karachi High Court 9 Sep. 1992, 3 AsYIL 206)

Under applicable international conventions Afghanistan is allowed to import goods duty-free through the Pakistani port of Karachi. In practice, however, many goods are smuggled back into Pakistan, chiefly to the border cities of Peshawar, Chaman and Quetta ('turn-around goods'), making it tough for Pakistani producers and sellers of legal goods to compete against the cheap, illegal imports.

In reverse direction Pakistani foodstuffs are being smuggled into Afghanistan where they fetch far higher prices, producing shortages in Pakistan.

In February 1995 Pakistan banned 15 items from duty-free export to Afghanistan, but the Afghan president accused Pakistan of trying to destroy the Afghan economy. (FEER 11-05-95 p. 59) 
IRAQ-KUWAIT WAR

\section{Easing sanctions against Iraq}

China welcomed Iraq's announced recognition of Kuwait and called on the international community on 11 November 1994 to consider the gradual lifting of sanctions against Iraq. China had abstained from almost all Security Council votes regarding the Gulf War, bound by its long-standing opposition to international interference in any country's internal affairs. (IHT 12/13-11-94)

\section{JAPAN'S MILITARY ROLE}

\section{Participation in Rwanda peace-keeping}

In the first international deployment of Japanese forces under Japanese command since World War II 470 members of the Armed Self-Defence Forces arrived in Zaire on 23 September 1994 to serve in the refugee camps. Unlike Japanese participation in peace-keeping in Cambodia and Mozambique when Japanese military were under the orders of UN officials, the mission to Rwanda would coordinate with the UN force but it would have its own independent command. (IHT 24/25-09-94)

\section{JOINT DEVELOPMENT AND JOINT VENTURES}

(see also: Foreign investment; Military cooperation; Oil and gas)

\section{Military joint venture}

India assured Russia a central place in India's defence purchases. Several Russian defence-industry agencies would form a joint venture with Hindustan Aeronautics to set up a workshop in India to overhaul Russian aircraft used by Indian and other regional armed forces. The term of a $\$ 830$ million credit line would be extended to allow India to buy Russian equipment. (FEER 14-07-94 p. 18)

\section{Completion of new Iranian petrochemical plant}

The biggest Iranian petrochemical plant so far was opened in early August 1994, making Iran the second-largest producer of petrochemicals in the Middle East. The project started as a joint venture with the Japanese Mitsui \& Co. which invested \$1.5 billion. The uncompleted plant was repeatedly bombed and wrecked during the IranIraq War. This and a changing petrochemical market led the Japanese to withdraw from the partnership, paying \$132 million compensation. The plant was completed with the assistance of Technip, a subsidiary of Société Nationale Elf Aquitaine and a French credit line of $\$ 850$ million. (IHT 03-08-94) 


\section{Growth triangles}

The idea of a 'Northern Triangle', floated in 1991 (see 1 AsYIL 329) began taking shape in 1994, incorporating the North Sumatra provinces, the Malaysian states of Kedah, Perlis, Perak and Penang, and the five southern Thai provinces of Narathiwat, Pattani, Yala, Satun and Songkhla. (Indonesia-Malaysia-Thailand Growth Triangle: IMT-GT) It was intended to be more loosely structured with only 'terms of reference' as a framework, in contradistinction to a formal trilateral agreement for the SingaporeJohore-Riau zone.

The IMT-GT Ministerial Meeting in Penang adopted on 16 December 1994 an open sky policy whereby national carriers of the three countries can fly anywhere they wish within the IMT-GT with limited government intervention. This was regarded a historic achievement. The meeting also agreed to the extension of the Malaysian-Thai border hours. (Star 22-08-94, NST 17-12-94)

The endeavours ran into problems, however, when Thailand refused in May 1995 to give preferential treatment to a Malaysian-led consortium bidding for a power project in Satun province. (FEER 15-06-95 p. 12)

More to the east an "East Asean Growth Area" is in the making (see 4 AsYIL 479), encompassing North Sulawesi, Sabah and Mindanao, while apparently the idea of a fourth growth triangle is being developed covering Kalimantan, East Malaysia and Brunei. (FEER 28-07-94 p. 30) Malaysia had been assigned to initiate moves to explore areas of cooperation in capital and financial services in the Brunei-Indonesia-MalaysiaPhilippines East Asean Growth Area (BIMP-EAGA). (NST 20-05-95)

\section{Greater Mekong Subregion}

All regional governments supported the plans for an infrastructural network conceived by the Asian Development Bank to link the economies of Myanmar, Laos, Thailand, Cambodia, Vietnam and southwestern China, constituting the 'Greater Mekong Subregion'. At a meeting in Hanoi in April 1994 the six countries agreed to cooperate and to conduct feasibility studies for 76 projects, mostly in the transport, power, telecoms and tourism sectors. The western part of the subregion including southern China, Myanmar, Laos and Thailand is also referred to as the Northern Growth Quadrangle. (FEER 01-12-94 p. 63; 22-12-94 p. 24)

\section{Trans-Asean gas pipeline}

The participating governments in the Indonesia-Malaysia-ThailandGrowth Triangle (IMT-GT) agreed in principle to a trans-Asean pipeline with the basis being provided by the Malaysian pipeline network. The project was first proposed in January 1994. (Star 16-12-94) 


\section{Gulf of Thailand}

The Cambodian foreign minister on 14 December 1994 urged Thailand to start joint development of marine areas in the Gulf of Thailand even before a settlement was reached on the overlapping Thai and Cambodian territorial claims.

Thailand and Cambodia last discussed sea boundaries in 1970, when talks broke down over the interpretation of a Franco-Siamese Treaty of 1907 establishing these boundaries. (BP 15-12-94)

\section{Tumen River development area}

It was reported that Russian and Chinese reservations at the meeting of the Program Management Committee in July 1994 had derailed the previously agreed Tumen River Area Development Corporation. (see 4 AsYIL 477) The Corporation was to be run by the three riparian countries (China, North Korea, Russia) to lease land and attract foreign investment. The Russian reservation was related to its own current economic difficulties.

As a result the original Tumen River Area Development project involving an industrial and processing zone at the mouth of the Tumen River centred on a new port city was shelved. It was supplanted by a revamped project, called the Tumen River Economic Development Area, spreading over a much larger area of about 10,000 kilometres, encompassing the area between Hunchun (China), Chongjin (North Korea) and Vostochnyy port (Nakhodka, Russia) but focused on more modest objectives, from removing cross-border impediments and facilitating air travel to promoting investment in telephone lines, and essentially involving coordinating development rather than imposing a grandmaster plan. A Trilateral Coordination Committee was established. (FEER 10-11-94 p. 46; JP 25-06-95)

\section{JUDICIAL ASSISTANCE}

\section{Indonesian-Australian extradition treaty}

After having concluded three extradition treaties with Malaysia (1974), the Philippines (1976) and Thailand (1978), Indonesia had signed its fourth treaty with Australia in April 1992. Parliamentary approval was given on 12 October 1994. (JP 1310-94)

\section{Cambodian request for extradition from Thailand}

Cambodia made a request to Thailand for the return of a general who was involved in a coup d'état (see supra p. 433) and had escaped to Thailand, to serve his sentence. There was no extradition treaty between the two countries. (FEER 17-11-94 p. 16) 


\section{Philippine-US extradition treaty}

An extradition and mutual legal assistance treaty was signed by the two countries during a stop-over by the US president en route to the APEC summit in Jakarta in November 1994. (FEER 24-11-94 p. 13)

\section{Hong Kong-Malaysia extradition treaty}

Malaysia and Hong Kong signed an extradition treaty on 11 January 1995 which will remain in force after the reversion of Hong Kong to China. The agreement was the fourth such agreement to be signed by Hong Kong. Previously Britain concluded the treaties on behalf of Hong Kong. Prior to the agreement with Malaysia, Hong Kong concluded extradition treaties with the Netherlands, Canada and Australia. (Star 12-0195)

\section{Sino-Italian agreement}

An agreement between the two countries on judicial assistance in civil matters entered into force on 1 January 1995. (BLD 1995)

\section{Extradition of national}

A Thai court decided to allow the extradition of a former MP to the US on drugtrafficking charges after the cabinet had decided to comply with the US request. (FEER 09-02-95 p. 13)

\section{Rendition of accused person by Pakistan and the Philippines to US}

A man who was accused by the US of having participated in the bombing of the New York World Trade Center on 26 February 1993, was arrested in Pakistan in a raid joined by US agents. The Pakistani government set aside procedures that would have delayed for weeks or months. It immediately turned over the man to the US FBI which flew him to the US aboard a military aircraft. (IHT 10 and 14-02-95)

\section{Sino-Indonesian agreement on legal assistance}

The two countries signed a memorandum of understanding on 11 January 1995 on the exchange of experiences and information in the legal field. (JP 12-01-95)

\section{Punishment in excess of extradition conditions}

In a corruption case China sentenced a person to death after his extradition by Thailand. In the extradition process, however, Thailand received assurance that the man would face a maximum 15-year prison sentence. (FEER 11-05-95 p. 13) 


\section{Indian request for extradition from Sri Lanka}

India called on Sri Lanka to extradite a number of Tamil separatists, all of whom wanted in connection with the assassination of RAIIV GANDHI. The request was made in spite of the fact that there was no extradition treaty in force between India and Sri Lanka. (FEER 15-06-95 p. 13)

\section{JURISDICTION}

(see also: Military cooperation, at p. 465)

\section{Russian territorial waters around the (disputed) southern Kuril Islands}

Russian border troops shot and killed two crewmen on a Chinese fishing boat which ignored orders to stop. The ship was detained and escorted to Shikotan Island. (IHT 14-09-94)

\section{Death edict against Salman Rushdie}

It was reported that the Iranian ambassador to Norway was recalled for "failing to act in accordance with Iran's principled foreign policy stand" with regard to the death edict against the author Rushdie. Iran rejects any change in the edict issued by the Ayatollah KHOMEINI but denies being involved in efforts to carry it out. (IHT 11-01-95)

At a meeting between senior Iranian diplomats and EU representatives the Europeans had formally pressed for an Iranian commitment to end pursuits of $\mathrm{Mr}$. Rushdie by Iranian agents in Europe. After a positive response appeared to be forthcoming Iran on 22 June 1995 affirmed it would not make any such express commitment. It seemed that there was some disagreement between the Iranian foreign ministry and the more militant surroundings of the Spiritual Guide of Iran. (IHT 23-0695)

\section{Overlapping Japanese and US exclusive economic zone}

The US Coast Guard on 12 May 1995 seized two Japanese fishing boats in the Pacific Ocean for illegal fishing in US waters. The boats were spotted fishing 52 kilometres inside the US exclusive economic zone near the Northern Mariana Islands. The Japanese foreign ministry confirmed that the boats were boarded and seized southeast of the Japanese island of Minami Iwo Jima. Both states maintain a 200nautical mile-exclusive economic zone that includes the area concerned. (IHT 15-05-95) 


\section{KOREAN WAR}

\section{China leaves armistice commission}

China announced on 2 September 1994 that it was withdrawing from the Military Armistice Commission that had been overseeing the armistice since 1953 (see infra). In a statement the Chinese deputy foreign minister said the withdrawal effectively rendered the Commission inoperative but that the armistice agreement remained in force. The South Korean government was informed of the withdrawal in advance.

The Commission consisted of North Korea, China and the UN Command, dominated by the US. South Korea as such was not a party to the armistice agreement and consequently not separately represented in the Commission. Ever since a South Korean had replaced an American general as representative of the 'UN Command' on 25 March 1991 (see, however, infra) North Korea had considered the Commission to have ceased to function and sought its elimination.

Earlier in 1994 North Korea established a separate office at Panmunjom (the Panmunjom Mission of the Korean People's Army) and pulled its delegation out of the Commission. It said it wanted to scrap the armistice and instead negotiate a formal peace treaty, but only with the US. China said it agreed with North Korea that a new agreement to protect the peace on the peninsula was required. (IHT 3/4-09-94)

\section{North Korean call for a new peace mechanism}

The Korean Armistice Agreement was signed on 27 July 1953 with the objective of ensuring "a complete cessation of hostile activities and all acts of armed force in Korea in order to cease conflicts".

In a letter from the North Korean representative to the UN addressed to the Security Council the US was accused of having violated the armistice agreement frequently by, inter alia, concluding the Mutual Defense Assistance Treaty with South Korea, and the introduction into Korea of large quantities of sophisticated weapons including nuclear weapons. It was said that the US thus had abrogated sub-paragraphs 13C and 13D of the Armistice Agreement on stopping the introduction of reinforcing military personnel and combat materials into Korea.

The letter recalled that North Korea, through a statement of 28 April 1994 of its ministry of foreign affairs, had proposed to the US that negotiations be held "for the establishment of a new peace arrangement which will replace the obsolete armistice mechanism, with a view to converting the armistice agreement into a peace agreement". (UN doc. S/1994/1092; S/1995/187; S/1995/461; FEER 15-09-94 p. 13)

[Note: UNGA res. $3390 \mathrm{~B}(\mathrm{XXX})$ called for the dissolution of the United Nations Command and the replacement of the Armistice Agreement with a peace agreement.]

The US insisted that any talks towards a new peace arrangement should first be held by North and South Korea. During his visit to Seoul in October 1994 the Chinese prime minister spoke of involving 'all concerned parties', referring to the two Koreas and China and the US: the two-plus-two formula. South Korea indicated it may accept this formula, but on condition that the peace treaty be first negotiated by the two Koreas while the two 'outsiders' would only 'endorse' the arrangement. Russia 
proposed to include Japan and Russia in the talks: the two-plus-four formula. (FEER 24-11-94 p. 34; 29-12-94/05-01-95 p. 15)

In line with its policy to scrap the armistice agreement and replace it with a peace treaty, North Korea on 28 February 1995 expelled the Polish members of the Neutral Nations Supervisory Commission from the Demilitarized Zone. Poland and Czechoslovakia had represented North Korea in the Neutral Nations Supervisory Commission whose task it was to oversee the armistice agreement. In 1993 Czechoslovakia already withdrew its delegation from North Korea, also under pressure of North Korea that did not permit the Czech Republic take over the duties of Czechoslovakia on the Commission. North Korea said that neither country was an ally anymore. (IHT 01-03-95)

According to North Korea, as a result of the US abrogation of sub-paragraphs $13 \mathrm{C}$ and 13D (above) of the Armistice Agreement, paragraphs 41 and 41, charging the Neutral Nations Supervisory Commission with the supervision of the ban on the introduction of military reinforcements, lost their legal effect so that the NNSC existed only in name.

On 3 May 1995 North Korea closed the only north-south border crossing to cease fire monitors, effectively banning neutral monitors from entering North Korean territory. (IHT 04 and 05-05-95; UN doc. S/1995/187)

On the anniversary of the start of the Korean War on 25 June 1995 North Korea warned of a danger of renewed hostilities unless the armistice is replaced with a peace treaty. (IHT 26-06-95)

\section{Membership of Armistice Commission}

The post of senior UN delegate at the Armistice Commission would again be filled by a US general. In 1991 a South Korean general was appointed, resulting in the boycott of the Commission by the North Koreans. (FEER 04-05-95 p. 13)

\section{LABOUR}

\section{Review of labour practices in Indonesia}

(see: 4 AsYIL 480)

The US Trade Representative's Office (USTR) had resumed its review of labour practices in Indonesia and intended to send an investigating team before August 1994. (FEER 01-09-94 p. 12)

The International Confederation of Free Trade Unions (ICFTU) condemned Indonesia's record on workers' rights, accusing the government of systematically crushing union activity. (FEER 20-10-94 p. 13)

\section{LOANS}

(see: Economic cooperation and assistance) 


\section{MIGRANT WORKERS}

(see also: Aliens; Diplomatic protection)

\section{Thai workers in Libya}

Libya pledged during a visit by the Thai deputy foreign minister that it would stop discriminating against Thai workers. A ban on Thai workers was introduced in 1993 because Thailand had taken action against three Thai companies after these were accused by the US of helping Libya with the building of an alleged chemical weapons plant in violation of international sanctions. (FEER 06-10-94 p. 13)

\section{Recruitment in Malaysia}

It was reported that Malaysia planned to recruit 50,000 Bangladeshi workers, doctors and nurses annually. There were already about 100,000 Bangladeshi employed in Malaysia, mostly in construction and plantation projects. The country needed about 1.3 million additional foreign workers. (FEER 13-10-94 p. 79)

\section{Filipino workers in Malaysia}

The Philippines filed a diplomatic protest with the Malaysian government over a round-up and detention of 307 Filipino workers in Kuala Lumpur on 22 October 1994. The Malaysian authorities claimed that the Filipinos had false working documents and passports, but 210 were released immediately. (FEER 10-11-94 p. 13)

\section{Foreign workers in Korea}

It was reported that among South Korea's estimated 85,000 foreign workers, about 55,000 were in the country illegally. The other 30,000 worked under a governmentsponsored technical-training program instituted to cope with the acute labour shortage. The program allowed 20,000 foreigners into the country in 1994 . They are normally allowed to remain for two years.

\section{Vietnamese workers in Lebanon}

In February 1995 the Vietnamese government ordered an investigation into the unfavourable condition of Vietnamese women sent to work in hotels in Lebanon but ending up as maids in private houses. As a result the labour-export service company arranged for the repatriation of all workers concerned. (IHT 17-05-95)

\section{Philippine migrant workers}

Millions of Filipinos have fanned out across the world. The president set off the exodus in 1974 when, facing economic disaster, the Filipinos were urged to go abroad to earn hard currency and reduce unemployment. According to government figures an 
amount of $\$ 2.6$ billion was sent into the country by workers abroad in the first eleven months of 1994. (FEER 30-03-95 p. 43)

A Philippine panel, set up by the president and led by a former Supreme Court judge, went on a 17-nation tour to investigate the conditions of Philippine migrant workers. The tour came in the aftermath of the conviction and execution of a Philippine maid in Singapore (see: Diplomatic protection). There are about 4 million Filippinos working overseas. (IHT 16-06-95)

\section{Vietnamese migrant workers in Germany}

(see: Aliens)

\section{Asian migrant workers in Israel}

Israel admitted about 5,000 farm workers from Thailand into the country since April 1994 to replace Palestinians from Gaza and the West Bank. The Thais are granted non-renewable two-year visas.

It was reported that the Philippine foreign minister tried to secure a quota for Filipinos during his visit to Israel in June 1994 but that the Israeli reply was negative because private employers decide themselves who to hire. An estimated 2,500 Filipinos are already working in Israel as domestic helpers. (FEER 28-07-94 p. 80)

On the occasion of the visit to China by the finance minister several economic agreements were signed, among which one on the import of several thousand Chinese guest labourers into Israel. (FEER 25-05-95 p. 29)

\section{MILITARY ALLIANCES}

\section{Malaysian-Philippine cooperation}

The two countries concluded a defence cooperation agreement. (BLD 10-10-1994 No. 20)

\section{The scope of the Philippine-US 1951 mutual defence pact}

With regard to speculations on US commitment to come to the aid of the Philippines in case of a Sino-Philippine dispute over the Spratly islands, it was reported that various US officials declined to answer 'hypothetical' questions as whether the US would intervene in case of an armed conflict between China and the Philippines over the islands. (IHT 06-06-95)

\section{US commitment to defend freedom of navigation}

The US Assistant Secretary of Defense said that the US "would be prepared to defend freedom of navigation" in the South China Sea because any interference would "infringe an important American interest as it would also infringe an important 
Japanese interest, since Japan is heavily dependent upon sea lines of communication for so many of its imports."

Under the Japan-US security treaty Japan is limited to securing the safety of its shipping through maritime surveillance and naval escort operations only as far as 1,000 nautical miles from the Japanese home islands, a radius that does not reach the South China Sea.

It was said that the focus of the Japanese-US alliance was being shifted from defence of Japanese territory to maintenance of international peace and security. The US Assistant Secretary indicated that the 'redefinition' would include establishment of a forum involving the US, Japan, China, Russia and North and South Korea to deal with security problems in Northeast Asia. (IHT 23-06-95)

\section{MILITARY COOPERATION}

(see also: Regional security)

\section{Australia - Indonesia}

In early August 1994 Australia offered to expand military training for Indonesia, despite a US Congress ban on small-arms sales to Indonesia the previous month (see supra, p. 388) and an earlier US decision no longer to provide military training or education to the Indonesian armed forces (see, however, infra p. 467). The Australian Defence Minister said that Australia and Indonesia were also considering a joint venture to produce military armaments and equipment. (IHT 04-08-94; FEER 11-08-94 p. 13)

In the context of a regular defence operation the two countries stage three to four naval exercises each year. In early August 1994 joint naval patrol manoeuvres were staged in the Timor Sea. (FEER 18-08-94 p. 13)

\section{Exchange of military attaches}

Malaysia and China agreed on 14 September 1994 to exchange military attachés to enhance cooperation, facilitate a faster flow of information and expedite planning of common programs and activities. (NST 15-09-94)

\section{Five Power Defence Arrangement}

Twenty-nine warships and 34 aircraft from Australia, Britain, Malaysia, New Zealand and Singapore held manoeuvres in the South China Sea in September 1994. They belong to the Five Power Defence Arrangement (FPDA) established in 1971 to help protect Malaysia and Singapore from external threats. The alliance requires its members to consult one another in the event of an attack on either country.

The defence ministers meeting in Singapore were adamant that the group was not an anachronism, considered the extension of air defence cover to East Malaysia and decided to invite Brunei to join. They were also adamant that their decisions had nothing to do with the issue of rival claims on the Spratly Islands. (IHT 23-09-94) 


\section{Malaysia-Philippines memorandum of understanding}

A memorandum of understanding was signed on 26 September 1994, aimed at providing the means and opportunities for greater interaction between the armed forces and defence agencies of the two countries. (NST 27-09-94)

\section{Sino-US military cooperation}

The commander of US forces in the Pacific said that the US planned to intensify military contacts with China, including the holding of joint exercises, as part of a strategy to gain Chinese support for new security arrangements in the Asia-Pacific region. This would mark a major thaw in military ties which were frozen by the US in 1989.

The formal resumption of the ties began in November 1993 with a visit to China by the US Assistant Secretary of Defense, and by the former commander of US forces in the Pacific in July 1994. In August 1994 the deputy chief of the Chinese armed forces general staff visited the US and the US Secretary of Defense visited China in October 1994, for the first time since 1989. (IHT 04-10, 17-10, 19-10 and 20-10-94) This visit was followed by further talks between arms negotiators in early November. (IHT 01-11-94)

The talks in October 1994 dealt with six issues: North Korea, the halt of longrange missile exports by China, the spread of nuclear weapons, human rights, defence conversion and the need to make the Chinese military more transparent. Both sides affirmed commitments to a nuclear-free Korean Peninsula, the end of missile exports and nuclear non-proliferation.

An accord was signed on 17 October 1994 on the creation of a Joint Defense Conversion Commission and providing for US assistance to help the Chinese military make more civilian products than they were already currently making. China would be provided with technology for 'environmentally safe vehicles' and for air-traffic control for civilian flights. This meant a turnabout from recent US policy of considering import sanctions on civilian goods made by US military enterprises. (IHT 18-10-94) It was also reported that the two countries agreed to hold broad strategic consultations, reviving ties that were frozen after the 1989 incident. (FEER 27-10-94 p. 13)

Later in November it was reported that the director of the US Defense Intelligence Agency visited China, being the highest level known contact by a US intelligence official since 1989. At that time the US and China were cooperating on a number of intelligence operations, including the monitoring of ballistic missile tests in the Soviet Union and covert operations in Afghanistan. (IHT 09-11-94)

As reported in February 1995 a US missile cruiser made a friendly visit to China at Qingdao in March 1995. It was the third US warship to visit China since the founding of the People's Republic in 1949, the second being at Shanghai in May 1989, shortly before martial law was declared during the anti-government demonstrations. (IHT 24-02, 24-03-95) 


\section{Rejection of US supply ships in South East Asia}

Thailand, Indonesia, Malaysia and the Philippines rejected a plan for US military supply ships to be based in Southeast Asia for possible use in emergencies. The arrangement would involve "civilian ships offshore with prepositioned equipment" and would enable US military reinforcements to be quickly flown to a crisis in either the Middle East or in Northeast Asia. The material could also be used for peacetime disaster relief. The US already had 'equipment afloat ships' anchored at the Diego Garcia atoll in the Indian Ocean and in Guam, and wanted to extend the network to include Southeast Asia.

It was expected that Singapore and Brunei would be equally reluctant to agree to the plan, the latter particularly after its decision in 1992 to have the US military base closed. Indonesian officials said that while Indonesia agreed that a US presence in Asia was necessary, it should not take the form of military bases. The countries concerned were also worried that an arrangement as proposed might raise suspicions in China. (IHT 08-11-94; FEER 10-11-94 p. 13; 01-12-94 p. 13; 19-01-95 p. 20) Consequently the US started considering the placing of floating arsenals, i.e. equipment on ships, anchored off its bases in Guam and Diego Garcia. (IHT 21-03-95)

\section{Japan-US joint manoeuvres}

US and Japanese forces started joint exercises on 8 November 1994 which were the largest between the two states in their 34 years of security alliance. The exercises were planned a year ago and named 'Keen Edge 1995'. (IHT 08-11-94)

\section{Use of Vietnamese naval base}

Upon utterances from US naval officers about the feasibility of the use of the Cam Ranh Bay naval base by the US navy the Chinese foreign ministry rejected the idea: "We are opposed to any foreign country establishing a military base or stationing troops on foreign soil." (IHT 19/20-11-94)

\section{Rejection of Philippine-US logistical agreement}

Contrary to original plans the Philippine government rejected a draft Acquisition and Cross-Servicing Agreement. The agreement was designed to facilitate port calls by US Navy ships and would allow the US military to buy goods and services up to $\$ 12$ million a year in the Philippines. In view of objections raised by nationalist circles the Philippine government sent the draft back to the Mutual Defense Board for revision. Certain provisions, such as one for 'storage services' could be interpreted as violating the constitution which prohibits "foreign military bases, troops or facilities". (IHT 2311-94) 


\section{Sino-Indian combined defence manoeuvres}

India and China agreed to hold joint military exercises in summer 1995 along the border in the Himalayan region of Ladakh. (IHT 17/18-12-94)

\section{Revival of Pakistan-US Military Group}

Pakistan and the US agreed to revive the Pakistan-US Military Group to hold regular discussions on security matters and issues like joint military training, military education programs and peace-keeping roles.

The forum was set up in 1984 at the peak of the war in Afghanistan, but was abandoned because of Pakistan's nuclear program. (IHT 12-01-95)

\section{Indo-US cooperation agreement}

During his visit to India in January 1995, the US Defense Secretary signed an agreement on policy discussions, intelligence exchanges, joint military training and exercises, and defence production and research. (FEER 26-01-95 p. 15)

It was later reported that the US and Indian navies held joint training exercises off the Indian west coast in mid-May 1995. (FEER 01-06-95 p. 12)

\section{Malaysia-Singapore cooperation}

The two countries signed a memorandum on joint ventures in the production, supply and marketing of military hardware. They also agreed to set up a joint peacekeeping force to join UN operations. (FEER 02-02-95 p. 13)

\section{Cambodian military training in Indonesia}

The Indonesian military was training Cambodian soldiers at its special warfare centre near Bandung, as part of non-lethal aid to Cambodia. (FEER 16-02-95 p. 12)

\section{US military presence in Asia}

The US "East Asia Strategy Report" which was released on 27 February 1995 disclosed that the US had no plans to make further troop cuts in Asia. These troops were cut back from 135,000 in 1990 to 100,000 in 1994, but the report said that cutbacks resulting from the end of the Cold War had finished. (IHT 28-02-95) Besides South Korea $(37,000)$ the US has military forces in Japan, Guam, Saipan, Singapore, Diego Garcia and Hawaii.

The Indonesian Foreign Ministry said that Indonesia does not want a US military presence nor any foreign military base in the region but admits that the US presence could balance China's military power. (IHT 01-03-95) 


\section{South Korea - Israel}

South Korea and Israel agreed to exchange army attaches for the first time since opening diplomatic relations in 1962. (FEER 16-03-95 p. 13)

\section{US military training for Indonesian officers}

Contrary to a US State Department testimony to the Congress on grave US concerns about the human rights situation in Indonesia, the vice-chairman of the US Joint Chiefs of Staff announced that the US was eager to resume training of Indonesian military officers which were suspended in 1992 in response to alleged human rights violations in East Timor. Accordingly the US Defense Ministry had applied for funds which, according to the State Department, were meant to "improve the overall professionalism and readiness of the Indonesian armed forces". (IHT 22-03-95)

\section{Normalization of Sino-European military relations}

European Union members decided in 1994 to lift restrictions on military exchanges contained in the Madrid Agreement (a package of sanctions drawn up in response to the June 1989 crushing of the anti-government demonstrations at Beijing).

The French armed forces chief was the first senior military official from a EU country to visit China in March 1995. The Austrian chief of staff was scheduled to visit in May, and the Italian armed forces chief later in 1995. (IHT 24-03-95)

\section{South Korean-Russian cooperation on weapons research}

An agreement was concluded on 21 May 1995 on mutual cooperation in the research and development of military supplies and possible joint production. (IHT 2205-95)

\section{South Korea-US Status of Forces Agreement}

On 20 May 1995 an incident arose when US soldiers molested a Korean woman in the subway in Seoul. This led the South Korean government to prepare for a renegotiation of the current SOFA agreement of 1967. The renegotiation would aim at the ability for South Korea to detain and prosecute US soldiers who break local laws while off duty instead of having to turn them over to the US military authorities. (FEER 01-06-95 p. 13)

\section{MINORITIES}

\section{Protection of Vietnamese minority in Cambodia}

A new Cambodian immigration law was enacted on 22 September 1994, authorizing the expulsion of all unwanted 'foreigners'. There was, however, no Cambodian 
nationality law yet to define the criteria for citizenship, leaving open the possibility to expel anyone who is not ethnic Khmer.

Nobody knows exactly how many ethnic Vietnamese live in Cambodia. Estimates range from 200,000 to 500,000, although the Cambodian Interior Ministry gave a figure of 100,300 in August 1994. Another estimate is that more than half of them arrived after Vietnam's 1978 invasion of Cambodia, causing legitimate concerns with Cambodia about the legality of their residence.

There is a deeply rooted fear in Cambodia that it, with a population of 9 million, would be swallowed up by Vietnam, which has 70 million inhabitants and not that much more arable land. By way of historical example, a large part of southern Vietnam, including the Mekong delta, was appropriated by the Vietnamese from the Khmer empire in the 18th and 19th centuries.

Vietnam said on 6 September 1994 it had asked the UN to help protect the rights of ethnic Vietnamese in Cambodia. (FEER 15-09-94 p. 13, 13-10-94 p. 20-21)

During talks in Hanoi the Cambodian co-premier promised that the some 150,000 ethnic-Vietnamese living in Cambodia would not be expelled. (FEER 02-02-95 p. 13)

\section{Chakmas in India}

The Chakmas are buddhist and their original home was in the Chittagong Hill Tracts in Bangladesh. Many still live there, but since the early 1950s a land conflict arose as Muslim plainsmen moved into the hill areas and put increasing pressure on the Chakma to leave. In 1964 a big group of Chakmas fled to India where they first settled in Assam state, from where many later moved to the area that became Arunachal Pradesh state in 1987. These 70,000 Chakmas in Arunachal Pradesh had demanded Indian citizenship but the Indian Supreme Court had ruled this out. The state government was also resisting these demands and wanted the Chakmas out of the state. This attitude was in accordance with a general anti-outsider agitation in several northeastern Indian states that started in 1979. Another 55,000 Chakmas fled persecution in the Chittagong Hills in 1986 and were given shelter in Tripura state. Following bilateral talks between India and Bangladesh, more than 5,000 returned to Bangladesh in 1994. (FEER 17-11-94 p. 20)

\section{MISSILE TECHNOLOGY}

(see also: Nuclear capacity; Weapons)

Sino-US dispute over transfer of missile technology (see: AsYIL Vol. 3 p. 425 , Vol. 4 p. 485)

It was reported in September 1994 that the two states were making attempts to resolve their dispute about supply of missiles by China to Pakistan. (IHT 27-09-94) On 4 October 1994 the two sides reached agreement on a definition of what constitutes a violation of the Missile Technology Control Regime (MTCR, see 1 AsYIL 270). China consequently agreed not to export missiles capable of at least 1,000-pound (500 kilograms) payload and 'inherently capable' of reaching a range of 300 kilometres. In 
exchange the US would lift the trade sanctions, consisting of a two-year ban on the export to China of high-technology satellite systems, imposed in August 1993 because of the alleged Chinese transfer of missile technology to Pakistan contrary to the provisions of the MTCR. China had always insisted that the M-11 has a range and payload below MTCR guidelines, and also denied that it had delivered M-11s to Pakistan. (IHT 05-10-94; FEER 20-10-94 p. 20) However, it was reported in mid-November that there was a US offer to waive possible sanctions if China would admit the alleged violations of the MTCR and fully disclose its past exports to Pakistan. (IHT 15-11-94)

\section{Chinese ICBM-test}

According to Japanese reports China test-fired a mobile long-range missile with a range of 8,000 kilometres. The missile is known as the Dongfeng-31. When it enters service China will become less vulnerable to the risk of a disabling first strike. (IHT 01-06-95) The Chinese foreign ministry declared not to be aware of the launching. (IHT 02-06-95)

\section{Alleged Chinese supply of missile components to Iran and Pakistan}

It was alleged in a CIA report that China had recently delivered important components for missile systems to Iran and Pakistan. China on 22 June 1995 dismissed the report and said it was complying with its treaty obligations. A dismissal also came from Pakistan. (IHT 23-06-95)

\section{NARCOTICS PROBLEM}

\section{US-Myanmar anti-narcotics operation}

The US decided to increase anti-narcotics cooperation with Myanmar despite objections from US human rights officials (see also supra, p. 432). The new policy called for an expansion in the training of Myanmar narcotics officials and financing UN efforts to encourage Myanmarese farmers to substitute other crops fro opium. (IHT 236-95)

\section{NATIONALITY}

(see also: Aliens; Divided states: China, at p. 405; Hong Kong; Minorities)

\section{Kazakhstan-Russia Agreement}

On 20 January 1995 an agreement was concluded "on a simplified procedure for the acquisition of citizenship" by citizens of one party taking up permanent residence in the territory of the other party.

The agreement refers to the Treaty on Friendship, Cooperation and Mutual Assistance of 25 May 1992 and to the "Memorandum on Basic Principles for Settling 
Questions Relating to the Citizenship and Legal Status of Citizens" of one party "who reside permanently in the territory" of the other party, of 28 March 1994 (see supra, p. 386)

The simplified acquisition of citizenship refers to acquisition by registration on the basis of the free expression of the will of the persons concerned, and is available for each of two categories of persons. First, those who in the past were citizen of the USSR and at the same time citizen of either the (former) Kazakh SSR or the Russian SFSR, and were residing in the territory of either as at 21 December 1991, and were a permanent resident of the party whose citizenship is sought before the entry into force of the present agreement, and second, those who have close relatives (spouse, parents, children, sisters, brothers, grandparents) who are citizens of the party whose citizenship is sought and who reside permanently in the territory of that party. (Art. 1) Although not expressly prescribed, the agreement gives the impression that acquisition of the citizenship of one party implies the renunciation and the consequent loss of the citizenship of the other party (Art. 2 para. 3: "In case where citizenship of one Party is acquired and citizenship of the other Party is simultaneously renounced ...") The agreement contains special provisions for the nationality of minor children (Art. 4).

Remarkably the Agreement prescribes that "[i]n cases where the domestic legislation of the Parties establishes more favourable conditions for the acquisition of citizenship for any category of individual, the domestic legislation of the Parties shall apply". (Art. 5 para. 2) (UN doc. A/50/83)

\section{NAVAL INCIDENTS}

(see also: Territorial claims and disputes)

\section{Sino-US incident}

It was reported that on 27-29 October 1994 the US aircraft carrier Kitty Hawk encountered a Chinese nuclear submarine in open waters off the Chinese coast in the Yellow Sea. The submarine was detected by US anti-submarine aircraft through electronic monitoring devices about 200 miles from the Kitty Hawk. When the submarine eluded the carrier group the US planes dropped sonic devices to track the submarine, whereupon Chinese jet fighters appeared and flew within sight of the US planes. The submarine then returned to Qingdao and the US carrier was pulled out of the area. (IHT 15-12-94)

\section{NON-ALIGNED MOVEMENT}

\section{Split on extension of NPT}

A meeting of members of the Non-Aligned Movement in April 1995 failed to reach consensus on the question of extension of the Nuclear Non-proliferation Treaty. Delegates were split almost equally between those in favour and those against an indefinite extension of the treaty. (IHT 28-04-95) 


\section{NUCLEAR CAPABILITY}

(see also: Weapons)

\section{North Korea}

(see also: Inter-state relations: general aspects at p. 435)

Contrary to earlier estimates the IAEA said that the close-down of the North Korean research reactor in 1989 lasted only 75 days instead of the initial estimate of 100 days, and there were doubts as to the North Korean ability of reprocessing at that time, so that it could only have obtained plutonium for a single bomb (In early August 1994 a South Korean newspaper quoted South Korean officials as saying that closedowns took place in 1989, 1990 and 1991 and that, consequently, North Korea could be presumed to have extracted enough plutonium for 3 to 4 bombs) (IHT 01-07-94,0808-94) Speaking about his findings after his visit to North Korea, former US President CARTER said that in the briefings he got from US intelligence services it was never alleged that North Korea had in fact built a nuclear bomb. (IHT 07-07-94)

[Note: According to the IAEA the approximate amounts of fissionable material needed for a single nuclear weapon are 8 kilograms of plutonium, 8 kilograms of uranium 233, or 25 kilograms of uranium highly enriched in the 235 isotope. These figures are known as threshold amounts or significant quantities and used to establish a wide range of industrial safeguards meant to deter and detect the diversion of materials from peaceful purposes to the making of nuclear warheads. (IHT 22-08-94)]

In further talks in early July 1994 the US offered a pledge of assistance in obtaining technology for North Korea to build a light-water reactor, less capable of producing plutonium. In exchange, work on the existing reactor would be halted and the structure dismantled, as would another, 25-megawatt reactor and a laboratory for reprocessing reactor fuel to separate plutonium. (IHT 08-07-94) On the other hand North Korea asked security guarantees and some form of diplomatic recognition from the US. (IHT 09/10-07-94)

After the talks were suspended as a result of the death of the North Korean president on 8 July 1994, the negotiations were resumed on 5 August but no progress was made. Meanwhile North Korea warned that it would have to start reprocessing the 8,000 spent nuclear fuel rods which were removed from the research reactor in June 1994 and which were stored in a cooling pond. (IHT 6/7-08-94)

Agreement in principle was finally reached on 13 August 1994 . North Korea would commit itself to freeze or abandon the reprocessing of the 8,000 spent nuclear fuel rods for the production of plutonium. It would freeze the construction of two nuclear reactors. It would also remain a party to the Nuclear Non-proliferation Treaty. In return the US would move toward establishing diplomatic and economic relations and would arrange to provide light-water nuclear reactors to replace the existing North Korean graphite reactors. Until the completion of the reactors by 2003 the US would supply 500,000 tons of heavy oil a year. The agreement was later signed on 21 October 1994.

On 15 August the South Korean president announced that South Korea was prepared to supply the modern nuclear power plants. Apparently the US leaned toward 
supply by South Korea rather than by Russia, as had been initially envisioned. North Korea, however, rejected the South Korean offer, saying that [t]he issue of the provision of the light-water reactor is a matter that must be settled between the DPRK and the US." (IHT 15 and 29-08-94, 22/23-10-94, 08-12-94) Later the South Korean foreign minister also said that South Korea was considering supplying the North with electricity until the safer nuclear plants are completed. (IHT 17-08-94) However, South Korea and the US suggested that before the provision of a modern nuclear reactor two undeclared nuclear sites in North Korea must have undergone inspection. This "special inspection" was crucial to know whether North Korea had reprocessed spent fuel into bomb-grade plutonium in the past. (IHT 18-08-94; FEER 25-08-94 p. 14) This demand was rejected by North Korea which said that it [was only] "willing to involve [itself] in clearing up nuclear suspicion in the future". (IHT 22-08-94)

In the course of the following US-North Korean negotiations in Berlin the US agreed that North Korea store the spent nuclear rods from its reactor in welded steel containers as an interim step pending their transfer to another country. This was in accordance with a North Korean demand that the spent fuel rods be preserved and retained on North Korean territory. (IHT 12-09-94)

The talks covered several aspects of the nuclear issue, such as who would provide the light-water nuclear reactors, and how North Korea's power demand would be met in the time before the new reactors were constructed, and what would happen to the 8,000 spent nuclear fuel rods. Also North Korea had asked that the new nuclear plants be financed with a no-interest, long-term loan that would be paid back not with cash, but with goods of some kind, perhaps electricity produced by the plant itself. (IHT 1509-94)

The plan would cost $\$ 4$ billion and take 10 years. (IHT 16-09-94) The US side said it was considering the project to consist of two 1000-megawatt reactors of a design like that of reactors currently under construction in South Korea. (IHT 17/18-09-94)

On 18 September North Korea announced that it had frozen its nuclear reactor program, as promised, and vowed to dismantle the remaining elements. (IHT 19/20-0994)

At the talks which were resumed in Geneva on 23 September new demands were made by North Korea, such as payment of $\$ 2$ billion in cash as compensation for North Korea's abandonment of the development of its graphite-moderated reactors. North Korea also demanded that the light-water reactors be constructed by Germany or Russia. This would greatly complicate a deal, partly because neither Germany nor Russia was willing to provide the bulk of the financing. (IHT 24/25, 28 and 29-09-94)

After indications that it was ready to grant more access to its nuclear facilities North Korea allowed the IAEA inspectors access to a fuel-fabrication plant and a freshfuel storage building on 13 September 1994. They formed part of the seven declared nuclear sites.

The IAEA inspectors reported that North Korea apparently did not produce weapons-grade plutonium from February 1993 to March 1994 (see AsYIL Vol. 3 p. 429, Vol. 4 p. 492), the period in which it had been blocking inspections of its nuclear program. The IAEA Director General also reported to the Board of Governors that samples taken from the reprocessing plant in March and May 1994 (see 4 AsYIL 492) provided no evidence of plutonium production during the previous year. This report 
cast doubt on the widespread speculation that North Korea was producing plutonium while keeping IAEA inspectors at bay. (IHT 13 and 14-09-94)

Agreement was finally reached on 21 October 1994. (see Selected Documents) In order to carry out the tasks assigned to it under that agreement, an IAEA technical team visited North Korea from 23-28 November and held discussions which were useful and constructive. (UN doc. S/1995/353)

Since the agreement in principle was achieved, the US began assembling an international consortium to finance the plan. The discussions involved South Korea, Japan, China and Russia but also other countries in Europe and Asia. They would be invited to form an organization that has "an interest in working together to help resolve the nuclear issue" and play a role principally in providing the energy needs to meet North Korea's legitimate concerns. The group would also provide alternative energy for North Korea during up to 10 years between the shut-down of the graphite reactors and the starting of the light-water reactor. (IHT 23-09-94)

In a next stage the US, South Korea and Japan proceeded to set up an international consortium to underwrite the replacement of the North Korean graphite nuclear reactors. (IHT 15-11-94) Russia expressed disappointment about the North Korea-US agreement since Russia had been counting on supplying North Korea with light-water reactors. (IHT 16-11-94) China decided against taking part in the consortium. (IHT 18/19-02-95) A Korean Peninsula Energy Development Organization was finally established on 9 March 1995. (see Selected Documents). (IHT 10-03-95)

On 20 November 1994 technical experts of IAEA went to North Korea to monitor the 'freezing' of five graphite nuclear plants. (IHT 21-11-94) They confirmed that the nuclear facilities in Yongbyon and Taechon were not in operation and that construction work had stopped. (IHT 29-11-94)

On 5 January 1995 the US said it would start sending oil to North Korea before 23 January as the latter had so far complied with the agreement concerning its nuclear installations. (IHT 06-01-95)

The US and North Korea began a second round of expert talks on 17 January 1995 on the question of long-term storage of the 8,000 spent fuel rods from the experimental reactor. It was reported on 24 January that North Korea had agreed to put the rods in dry concrete as part of a new deal with the US (IHT 18 and 25-01-95)

Under the October Agreement both sides were to make their best efforts to conclude a reactor supply agreement within six months (by 21 April 1995). During the negotiations on the contract early February 1995, North Korea quite unexpectedly also asked another $\$ 500$ million to $\$ 1$ billion worth of extra economic and technical assistance to construct a simulator to train North Korean reactor operators, to install new transformer lines and electric-power sub-stations and to finance other reactor "accessories". (IHT 08 and 09-02-95) Furthermore, North Korea later proposed that the main contractor should be American, while South Korean companies could take part in a limited capacity. (IHT 29-03-95)

It was reported that the difficulties in reaching agreement on the implementation also had another reason: the failure of the US to begin liberalizing trade and investment relations by 21 January 1995. In the October agreement the two parties had pledged to "reduce restrictions on trade and investment, including telecommunications and financial transactions" within three months. Instead of making some significant step to 
implement this pledge the US government was reported to have made only token gestures, for fear of stirring Congressional opposition. (IHT 11-04-95)

Finally the Berlin talks failed, and new talks were started on 20 May 1995 at Kuala Lumpur which initially proceeded favourably. (IHT 20/21 and 23-05-95) During these talks North Korea again demanded additional compensation for power lines and infrastructural improvements, estimated at $\$ 1$ billion. As to the origin of the reactors the North Korean foreign ministry reiterated that while it did not matter where the reactors were made, they must carry a "Designed in America" label. (IHT 06-06-95)

On 7 June 1995 the two parties were able to announce that tentative agreement had been reached. (IHT 08-06, 12-06-95) It was signed on 13 June. (see: Selected Documents) Since North Korea refused to accept an agreement stipulating that it would receive reactors from South Korea, and since South Korea did not want to pay for the reactors unless the contract clearly stated that South Korean reactors would be used, this had, consequently, to be set forth in a side letter from the US to South Korea. Within the Korean Peninsula Energy Development Organization, consisting of the US, South Korea and Japan, it was agreed that the government-owned Korea Electric Power Company would be prime contractor for installation of the reactors. The latter would select a US firm as programme coordinator to oversee the project and act as a gobetween. (IHT 14-06-95; FEER 29-06-95 p. 22)

\section{Pakistan}

The former Pakistani prime minister, NAWAZ SHARIF, said at a rally in the Pakistani sector of Kashmir on 23 August 1994 that both India and Pakistan had nuclear weapons. In a 1993 interview with a London-based Pakistani newspaper a retired army chief-of-staff had already said that Pakistan had carried out its first successful test in cold laboratory conditions in 1987.

Pakistan as well as India officially deny having the bomb. Responding to the above statement a foreign ministry spokesman said: "In the course of its development of a peaceful nuclear program, Pakistan has acquired the capability to acquire nuclear weapons, but we have made a sovereign decision not to produce them." (IHT 24 and 25-08-94)

During a visit to the US the Pakistani prime minister confirmed that the nuclear project at Khushab involved a small reactor for an experimental purpose. She emphasized that Pakistan lacked the capability eventually to reprocess the reactor's spent fuel in order to separate the plutonium which could be used in nuclear weapons.

US officials said that the reactor was a so-called heavy-water reactor with a capability of 40 megawatts. As a reactor built largely with indigenous technology it would not be subject to international inspection. According to US intelligence reports the nuclear weapons allegedly already in possession of Pakistan are based on a Chinese design using highly enriched uranium as the fuel for nuclear fission. Smaller and more powerful plutonium-based weapons were said to fit more easily onto ballistic missiles. (IHT 10-04-95) 


\section{India}

In an attempt to stem the spread of missile technology a meeting in New Delhi of a US-led group of countries (US, Britain, Switzerland and Australia) pressed India and Pakistan to renounce their atomic weapons programs. (IHT 31-08-94)

India announced on 5 January 1995 that it had received a supply of enriched uranium from China. It would be mixed with domestically produced plutonium oxide and used to fuel the Tarapur atomic power plant near Bombay. It had thus avoided a hold applied by Western countries in their effort to press India into the existing safeguards and non-proliferation arrangements.

Most of India's reactors are locally designed and use natural (non-enriched) uranium. These reactors are outside international controls, and their spent fuel can be reprocessed to extract plutonium for atomic weapons. But the Tarapur plant, commissioned in 1969, has two 160-megawatt units supplied by General Electric and uses imported enriched uranium as fuel. Under a 1963 tripartite agreement with the US and the IAEA, Tarapur is subject to regular inspections and monitoring. After India's explosion of a nuclear device in 1974, the US withdrew from its arrangement to supply enriched uranium. Then France stepped in with a long-term agreement which expired in 1993, and Russia too decided to require adherence to the non-proliferation obligations for the supply of enriched uranium. Developing a uranium-enrichment facility for just one plant would be uneconomical. The Chinese uranium would be lowenriched and not weapons-grade, and would be subject to IAEA safeguards throughout the fuel cycle at Tarapur. (FEER 19-01-95 p. 22)

\section{Japan}

The US Energy Department announced in early September 1994 that the US would stop export of technology to Japan for the refinement of bomb-grade plutonium from breeder reactors. These exports had been taking place for the past seven years, despite the official US position against the export of any technology conducive to the spread of nuclear weapons. (IHT 10/11-09-94)

At the end of 1993 Japan's stocks of plutonium amounted to more than 10,000 kilograms. About $60 \%$ was held at plants in France and Britain that reprocess spent fuel from Japanese nuclear-power stations. A further 3,000 kilograms was stored at a government fuel fabricating plant in Ibaraki prefecture. (FEER 08-12-94 p. 13)

\section{Chinese nuclear test}

China continued its testing of a new generation of ballistic missile warheads by exploding a nuclear device beneath its western desert on 7 October 1994. The test was part of a series that was undertaken to verify the reliability of miniatured warheads designed during the 1980 s for use with Chinese strategic missiles. The Chinese foreign ministry confirmed the test and said that "China will put an end to its nuclear tests" as soon as negotiations on a comprehensive nuclear test ban treaty would be completed in 1996. 
It was China's 41 st nuclear test since 1964, compared to 44 by Britain, 210 by France and more than 1,000 by the US. (IHT 8/9-10-94)

In the fall of 1994 the US Defense Secretary raised the idea of offering China sophisticated computer simulation programs as a substitute for nuclear testing. (IHT 18/19-02-95)

On 15 May 1995 another underground test took place at the Lop Nor testing site in the western province of Xinjiang. The blast drew sharp protests from many of China's neighbours, especially Japan, Kazakhstan and Australia. At the session of the Disarmament Conference at Geneva further criticism was expressed by Japan and four other non-nuclear states: Finland, New Zealand, Argentina and Belgium. China was expected to conduct two to four more tests later in 1995. (IHT 16-05 and 02-06-95)

\section{Light-water nuclear reactors for China}

China and South Korea were due to sign an agreement in November 1994 on construction of two light-water nuclear reactors in China. (FEER 17-11-94 p. 13)

\section{Japanese nuclear waste transport}

Japan decided not to disclose the route of the "Pacific Pintail", a freighter owned by British Nuclear Fuels Ltd, which was to carry nuclear waste from Europe to Japan. The ship was to depart from Cherbourg on 23 February 1995. The waste had resulted from the reprocessing of spent nuclear material into fuel-grade plutonium. (see also 3 AsYIL 428) (IHT 22-02-95) On 28 February 1995 an Indonesian official said that Japan had guaranteed that the ship (with 13.7 tons of radio-active material) would not pass through Southeast Asian waters. (IHT 01-03-95) The ship arrived in Japan on 25 April 1995. (IHT 26-04-95)

It turned out that the ship had been routed around South America. The Panama Canal-route was avoided to prevent expected protests. This was ironic because the canal was used for more than 140 shipments of spent fuel from Japan to France and Britain over the last decade and experts usually consider spent fuel a marginally more risky cargo than reprocessed nuclear waste. (FEER 18-05-95 p. 12)

\section{US purchase of Kazakhstan uranium}

The US purchased and transfered an amount (some 600 kilograms) of enriched uranium from Kazakhstan to the US, putting it, according to the US Defense Secretary, "forever out of the reach of potential black marketeers, terrorists or a new nuclear regime". The operation was carried out with the knowledge and approval of the Kazakhstan government and Russia. The transaction was a result from a declaration by the US government in September 1993 that it was prepared to "pursue the purchase of highly enriched uranium from the former Soviet Union and other countries and its conversion to peaceful use". (IHT 24-11-94) 


\section{Progress of nuclear developments in Iran}

It was reported that "senior American and Israeli officials" had reached consensus that barring interruption "by some foreign power" Iran was more or less five years away from having an atomic bomb. These conclusions were being drawn despite the fact that Iran had done little more than amass nuclear material and some equipment, such as a neutron source reactor and an isotope separator. It had yet to build a nuclear reactor that can be used to develop nuclear weapons. Iran possesses three research reactors, among which an American one which has lacked supply of high-grade uranium since 1979. Besides Iran has at its disposal some laboratory facilities ("hot cells") for plutonium fission, and a quite small electromagnetic 'calutron' supplied by China. The worries were in fact predicated by the assumption that "the Iranians will be able to take quantum leaps in their push to collect the components needed to build an atomic weapon". "Senior Israeli officials" were also quoted as saying that if the program was not halted they would be forced to consider attacking Iran's nuclear reactors, as they did in 1981 when Israeli warplanes bombed Iraqi nuclear reactors.

According to the same reports the most active centre for nuclear weapons research and production is in Bushehr, 750 miles south of Teheran. It has two 1,300 megawatt reactors under construction. (IHT 06-01-95; NRC 07-04-95)

Russia agreed to complete the war-damaged Bushehr nuclear power station, and thus revive a project abandoned by German contractors on alleged breach of contract by the Iranian government after the 1979 Islamic Revolution. After the Iraq-Iran War the German government forbade the resumption of the project on the instigation of the US. The first of the projected two Russian units would be operational within four years. (IHT 09-01-95; NRC 07-04-95). The project which included the sale of light-water nuclear reactors was confirmed despite US protests. The deal would be worth $\$ 800$ million to $\$ 1$ billion. The Germans had withheld key blueprints and technical documents relating to the site, making it more difficult to fit 1,000-megawatt Russianmade reactors and turbines into a damaged structure intended for German-designed 1,200-megawatt reactors.

The US had provided Russia with an intelligence report on Iran's alleged ambitions to build a nuclear bomb, and had promised the Russian Atomic Energy Ministry huge projects to compensate Russia for abandoning the Iran contract. According to US officials the report showed that Iran had imported equipment needed to build nuclear weapons and that it had sought to buy enriched uranium from former Soviet republics like Kazakhstan.

Both the Russian foreign ministry and the atomic energy ministry denied that the light-water reactors could be used to create nuclear weapons, and said that Iran had not previously violated atomic agreements. (IHT 04-04 and 20/21-05-95) But according to US sources Russia had provided assurances that it did not intend to proceed with a part of the deal that particularly worried the US, viz. the proposed sale of a gas centrifuge plant that would have provided Iran with a supply of enriched uranium that could be used to make nuclear bombs. The spokesman for the Russian foreign ministry said that the plan was still being debated. (IHT 05-05-95) 
In February 1995 the Chinese Foreign Ministry emphasized that China and Russia were justified in selling civilian nuclear technology to Iran as long as it is done under the safeguards of the IAEA. (IHT 18/19-02-95) It said on 29 March 1995 that it had fulfilled its commitments against nuclear and chemical arms proliferation in its relations with Iran, and dismissed Western charges that China and Iran were engaging in transactions of nuclear and chemical weapons technology. (IHT 30-03-95) A couple of weeks later the Chinese foreign minister again rejected a plea by his US colleague not to go ahead with the sale, saying: "We respect the views of the United States, but what we are doing is consistent with international practice" and adding that no international law prohibited the deal.

Under a 1992 agreement China would build two 300-megawatt pressurized water reactors in Iran and provide nuclear know-how. Several years ago China sold Iran a small research reactor and an electromagnetic isotope separator that could be converted to enrich a small amount of uranium for research. (IHT 18-04-95) In May 1995, however, Chinese officials divulged that there were difficulties over the terms of the implementation of the agreement, such as regarding the site and other matters. (IHT 18-05-95)

On 23 March 1995 the head of the Russian intelligence agency said that his agency did not support the US contention that Iran is developing nuclear weapons. The statement said that Iran's level of achievement in the nuclear field did not exceed that of another 20 to 25 countries. The agency report said that, without help from outside, Iran would not be capable of organizing the production of weapons-grade nuclear materials. (IHT 24-03-95)

In May 1995 the director of Iran's Atomic Energy Organization stated that Iran intended to build a number of nuclear power plants (the reported number of ten was later denied and corrected to three) in the next two decades, but denied accusations that Iran was trying to develop nuclear weapons. Iran had already invested $\$ 6$ billion in the project.

He told that a formal contract with China was signed in 1994 for two nuclear power reactors. Chinese experts had completed a feasibility study and had begun to draw up blueprints and engineering reports for a site in southern Iran. Iran had already made a down payment for the project which would cost $\$ 800$ million to $\$ 900$ million. $\mathrm{He}$ denied that Iran had ever negotiated a plan to buy a gas centrifuge from Russia that could have rapidly enriched uranium to bomb-grade quality, and also denied that there existed a parallel nuclear program through the military. (IHT 15 and 18-05-95)

\section{Extension of Nuclear Non-proliferation Treaty}

(see also: Non-aligned movement)

In facing the projected conference on the permanent extension of the NPT, about 90 developing states were resisting a US-led effort towards an unconditional, indefinite extension. The objection was based on the view that the nuclear powers had not sufficiently pursued nuclear disarmament, resulting in the Treaty turning out to be a bad deal: on the one hand the commitment not to seek to obtain nuclear weapons, on 
the other hand a consolidation of the nuclear powers' military and political superiority. The overall number of US and Russian strategic nuclear arms had become more than twice the number at the time of signature of the Treaty. As a result the developing countries aimed at linking the extension to new steps toward disarmament.

Another issue complicating the drive towards extension of the Treaty was the fact that Israel, which has a substantial, undeclared nuclear arsenal, had not signed nor did it intend to sign the Treaty, nor had the US ever pressured it to endorse the Treaty. US officials were referred to as having said that it is a waste of time to urge Israel to adhere to the treaty as it has since long relied on its nuclear arsenal as the ultimate security guarantee and is highly unlikely to sign the treaty. (IHT 02-03-95)

[Note: For adherence of Asian countries to the NPT: see 3 AsYIL 256]

At the conference on the renewal of the NPT it was reported that a compromise was being forged on the basis of a split among the 111 members of the Non-Aligned Movement. (IHT 10-05-95)

\section{Sino-US nuclear cooperation agreement}

According to a US official China's negative response to US objections to a prospective Sino-Iranian deal on nuclear equipment (see above) would influence the implementation of a recently signed Sino-US nuclear cooperation agreement, meant to give China access to US civilian nuclear technology. Under US law US sales would not be permitted unless the President testified to Congress that China's nuclear trade with Iran and Pakistan was appropriate. (IHT 18-04-95)

\section{Protests against French nuclear tests}

Japan on 14 June 1995 accused France of betraying the trust of non-nuclear states by deciding to resume nuclear testing. (IHT 15-06-95)

\section{OIL AND GAS}

(see also: Foreign investment)

\section{Vietnamese offshore oil production}

It was reported that oil began flowing from the Dai Hung field off Vietnam's southeastern coast. Vietnam expects an increase in oil output to about 20 million metric tons a year by 2000 , from 6.3 million tons in 1993. (IHT 17-10-94)

In February 1995 BP, together with Statoil (Norway) and Oil and Natural Gas Corporation (India) announced the first commercial gas discovery off Vietnam, in the Nam Con Son basin of the South China Sea, which is also claimed by China. The area, some 450 kilometres southeast of Ho Chi Minh City, is claimed by Vietnam as part of its continental shelf. Oil and gas discoveries in the year ending May 1995 led to a major upgrading of Vietnam's petroleum and gas prospects. (IHT 25-05-95) 


\section{Central-Asian pipelines}

Depending on financing the building of a pipeline from Turkmenistan through Iran and Turkey to the Mediterranean would start early 1995 . When completed it would enable the transport of gas from Turkmenistan to Europe while bypassing Russia.

Kazakhstan formed a consortium with Oman to build a pipeline through Russian territory to the Black Sea, in order to avoid dependence on Russian pipelines. (IHT 19/20-11-1994)

\section{OPEC}

The organization held a meeting at Bali, Indonesia and decided on 22 November 1994 to freeze oil output through the whole of the next year, holding daily production at 24.5 million barrels. Before the middle of November the price for the OPEC basket of crude oil averaged $\$ 16.97$ a barrel, compared with its target of $\$ 21$. In inflationadjusted terms, the price was not much higher than it was before the 1973 oil embargo.

OPEC's members in 1994 were Algeria, Gabon, Indonesia, Iran, Iraq, Kuwait, Libya, Nigeria, Qatar, Saudi Arabia, the UAE and Venezuela. (IHT 21 and 23-11-94)

\section{China}

China became a net importer of oil for the first time in 1993. (IHT 03-01-95)

In early June 1995 China announced details of its annual round of bidding for oil exploration tracts in the Tarim and Junga basins in Xinjiang Province. The interest of foreign oil companies in the Tarim Basin had fallen off because of the cost of operating in harsh desert conditions and the potential problem of transporting crude oil. Under the terms offered by China the foreign companies bear 100 percent of the exploration risk, while China National Petroleum reserves the right to a 51 percent stake if oil is found. (IHT 09-06-95)

\section{Thai-Myanmarese gas agreement}

The Thai State Petroleum Authority signed an agreement to import natural gas from Myanmar starting in 1998. The project includes sending gas through a 400kilometre pipeline from the Gulf of Martaban overland to the Thai border.

Mon and Karen guerillas who operate in the territory oppose the project as providing revenue for the Myanmar government. (IHT 03-02-95) 


\section{PASSPORTS AND VISAS}

\section{Malaysia-Thai border smart card system}

The ministerial committee of the Indonesia-Malaysia-Thai Growth Triangle endorsed a proposal on 16 December 1994 to replace border passes at the MalaysiaThai border with smart cards for frequent travellers. The smart card, similar to a credit card, would simplify immigration procedures, reduce immigration manpower and provide easier access between the two countries. (Star 17-12-94)

\section{Border identification cards in lieu of passports}

Under the Second Protocol (1994) to the 1967 Malaysia-Philippine Anti-Smuggling Co-operation Agreement, which was due for signature on 29 March 1995, border residents of both countries would be issued with special border identification cards, replacing the need for international passports. (NST and Star 29-03-95)

\section{PIRACY}

\section{Increase and decline of piracy in 1994}

According to the annual Piracy Report, issued by the Regional Piracy Center (which was created in 1991 by the International Maritime Bureau), incidents of piracy worldwide declined in 1994, but increased in the Indonesian archipelago.

There were 90 incidents of piracy around the world, against 103 in 1993 and 115 in 1992. In Southeast Asia there were 33 incidents, compared with 15 in 1993, while the number of incidents in the Indonesian archipelago doubled, from 11 to 22 .

In East Asia the number sank to 38 from 68 in 1993, the South China Sea having had 14 incidents. Three incidents were reported in Southwest Asia, down from 5. (IHT 15-02-96)

\section{Instances of piracy in the South China Sea}

A Panama-flagged freighter, on its way from Singapore to a Cambodian port, was hijacked off the Vietnam coast on 23 June and headed for Chinese waters. Another freighter was hijacked on 24 March and towed to San Wei in Guangdong, China. (IHT 27-06-95)

\section{RECOGNITION}

Visit of Pakistani prime minister to Gaza

On an invitation of the Head of the Palestine Liberation Organization the Pakistani prime minister planned to visit Gaza during her trip to Egypt in September 1994. Since 
Pakistan does not recognize Israeli authority in the Occupied Territories the prime minister planned to enter the Gaza area without Israel's permission.

Israel stated that the self-rule agreement did not give the PLO the right to grant visas to enter the Gaza strip, and barred the Pakistani prime minister. Although Israel later authorized the visit after intervention by the Egyptian president the Pakistani prime minister decided not to reschedule the aborted visit. (IHT 01-09-94)

\section{REFUGEES}

\section{Indochinese refugees}

The International Conference on Indo-Chinese Refugees, Geneva 13-14 June 1989, had adopted the Comprehensive Plan of Action (CPA), being a framework for international consensus and cooperation between first-asylum and resettlement countries, Vietnam, Laos, and the UNHCR, and aimed at a comprehensive solution of the problem of refugees and non-refugees from Vietnam and Laos. Its objectives were (1) discourage clandestine departures, (2) assure access to a status-determination process for all asylum-seekers, (3) provide resettlement opportunities for those qualified as refugees, (4) repatriate in safety and dignity those volunteering or not fulfilling refugee criteria.

During 1994 7,018 Vietnamese and 6,187 prima facie Lao refugees were resettled, and 12,555 Vietnamese and 7,018 Lao were repatriated voluntarily within the CPA framework. In the first four months of 1995, 1,079 Vietnamese and 2,166 prima facie Lao were resettled, and 3,084 Vietnamese and 1,282 Lao repatriated voluntarily. [From mid-May 1995 interest in voluntary repatriation declined to negligible levels due to renewed expectations of resettlement to the US.]

The (sixth) Steering Committee meeting of the International Conference on IndoChinese Refugees on 16 March 1995 established 31 December 1995 as the target date for the conclusion of activities under the CPA in ASEAN countries and shortly thereafter with regard to Hong Kong. (UN doc. A/AC.96/846/Part II/10)

\section{Sri Lankan refugees}

8,147 Sri Lankan refugees repatriated from India in 1994. There was an acceleration in the repatriation rate to 10,013 during the first quarter of 1995 , due to the cessation of hostilities between government forces and Tamil insurgents which was in effect from 8 January to 19 April 1995. More than 31,000 persons had returned since July 1992, and approximately 54,000 refugees were still in the Indian state of Tamil Nadu. (UN doc. A/AC.96/846/Part II/10)

\section{Myanmar refugees}

In 199480,000 Muslim refugee residents of the Rakhine State in Myanmar returned from Bangladesh under the auspices of UNHCR, leaving some 120,000 scheduled to return during 1995. (UN doc. A/AC.96/846/Part II/10) 


\section{Afghan refugees}

329,400 Afghan refugees returned to Afghanistan in 1994, comprising 226,700 from Iran and 102,700 from Pakistan. They joined more than 3 million who had returned between 1990 and 1993. 2.6 million Afghans still remained in neighbouring countries. (UN doc. A/AC.96/846/Part V/13)

\section{Refugees in Iran}

At 31 December 1994, 1,623,000 Afghans and 118,000 Iraqi refugees were in Iran. In addition, there were 68,000 persons of undetermined nationality, the majority appearing to be Tajiks, Azeris and Bosnians. (UN doc. A/AC.96/846/Part V/6)

\section{Vietnamese refugees in Indonesia}

Indochinese 'boat people' had been concentrated on Galang island, south of Singapore. From the 145,000 people who had landed in Indonesia since the late 1970 s, 132,000 had been resettled during the first ten years. Since the adoption of the Comprehensive Plan of Action in 1989, 4,500 people had been voluntarily repatriated.

Seven months after the completion of the screening by the resettlement countries there was some revolt and virtual take-over of the island by a number of the remaining 8,000 Vietnamese and Cambodians who were not eligible for resettlement. (FEER 1407-94 p. 16)

\section{Vietnamese 'boat people' in Hong Kong}

Vietnam agreed to hold talks with Britain in January 1995 on the repatriation of all Vietnamese refugees being held in Hong Kong before the colony would revert to Chinese rule. About 27,000 Vietnamese were still in detention camps. (IHT 21-12-94)

\section{Repatriation of Vietnamese refugees}

Representatives of about 30 Asian countries attended the sixth technical committee meeting on Indochinese refugees in Kuala Lumpur in February 1995 to discuss ways to speed up the repatriation of the still remaining Vietnamese refugees. According to the UNHCR 5.5 percent of the 839,000 people who left Vietnam since 1975 were still in Asian 'first asylum' countries. So were 3.2 percent of the 360,000 who fled Laos. There were still more than 5,000 'boat people' in Malaysia, some 6,000 in Indonesia and 22,000 in Hong Kong.

The conference agreed on 23 February that all Vietnamese in Asian camps would be repatriated by the end of 1995, while Hong Kong was to complete the process 'shortly afterwards'. The UK representative for Hong Kong confirmed the process would be completed in 1996. China had told the meeting that it would not permit Hong Kong to remain a place of asylum after it had take over the territory in 1997. 
All efforts would be made to get the refugees back to Vietnam voluntarily, but if this failed the repatriation would be carried out under the Orderly Repatriation Program. The Vietnamese government agreed to accept 3,600 refugees a month.

Before the conference agreements had already been concluded between the UNHCR, Malaysia and Vietnam and between the UNHCR, Indonesia and Vietnam. (IHT 22 and 24-02-95, 16-03-95; NST 24-02-95; Star 18-02, 22-02 and 24-02-95)

\section{REGIONAL SECURITY}

\section{Military exercises in the Persian Gulf}

The US, Britain and Kuwait held joint military exercises off the Kuwaiti coast, close to Iranian territorial waters. Shortly after the end of the exercises Iran warned the US on 4 October 1994 against 'illegal military operations' in the Gulf, accusing US forces of having provoked Iranian helicopters and ships in the region. Iran demanded through the UN that the 'illegal movements' of US forces in the Gulf be stopped. (IHT 05-10-94)

\section{ASEAN Regional Forum}

(see also: 4 AsYIL 505)

The first formal talks among 18 states in the context of the Forum took place on 25 July 1994 at Bangkok. Apart from the ASEAN member states the meeting was attended by the US, Russia, Japan, China, South Korea, Vietnam, Australia, New Zealand, Canada, Laos, Papua New Guinea and the European Union. (IHT 25-07-94)

The meeting represented the first time such things as preventive diplomacy and the need for transparency in the region's arms build-up were discussed under ASEAN sponsorship. (FEER 04-08-94 p. 14)

The meeting agreed on annual talks and on developing measures to defuse potential conflicts but there was no determination of detailed steps to be taken. Officials envisaged that such steps would likely include exchanges of non-classified military information, cooperation in regional peace-keeping, and registering purchases of conventional arms. (IHT 26-07-94)

\section{Indo-US security agreement}

India and the US signed a security agreement on 12 January 1995 . The agreement calls for joint military exercises and training, greater cooperation and consultation between the armed forces, defence research collaboration and joint production of military hardware. The agreement refers for the first time to regular cooperation between civilians of both defence ministries, who will form a group that would review post-Cold War strategy. On the military side, the agreement calls for more high-level exchanges between services, and training and joint exercises at progressively higher levels of scale and sophistication. It also calls for expanded defence research and production. (IHT 13-01-95) 


\section{RIVERS}

(see also: Environmental pollution and protection)

\section{Mekong River cooperation}

On 5 April 1995 Cambodia, Laos, Thailand and Vietnam concluded an Agreement on the Cooperation for the Sustainable Development of the Mekong River Basin (see Selected Documents).

A couple of days later Thailand proposed ideas on better exploitation of the river. Thai and Cambodian officials would hold discussions in May 1995 on a hydro-electric dam project that would provide water to Thailand in exchange for electricity to Cambodia. The project would use three dams to divert water from the Strung Nam river in southwest Cambodia to Thai power plants in Trat Province. Electricity would be generated in an aqueduct between the countries and would be sent back to a power station in Cambodia. Thailand also proposed that Laos divert water during the rainy season from its northwestern townships to a northern Thai reservoir. Under this plan Thailand would build a 38-kilometre aqueduct to carry water south across the border. (IHT 10-04-95)

\section{Ganges River water-sharing}

The Indian and Bangladesh prime ministers discussed the water-sharing issue at the SAARC-meeting at New Delhi in early May 1995. Bangladesh was accusing India of diverting the river flow and thereby reducing the flow of water to a level of 9,000 cubic feet per second, from the level of 34,000 cubic feet agreed to in 1977. (IHT 0905-95) Indo-Bangladeshi talks ended on 25 June without any breakthrough. However, it was agreed to re-activate the Joint Rivers Commission which had not met for the past five years, to "work out details on sharing of the waters of common rivers, including the Ganges, on a permanent basis." (IHT 26-06-95)

\section{SANCTIONS}

(see also: Inter-state relations:general aspects; Iraq-Kuwait War)

\section{Remaining US sanctions against China}

The US decision in late May 1994 to extend the MFN-status of China did not affect certain measures taken by the US as a response to the 1989 Beijing incidents, such as the ban on development funds for China. The sanctions specifically bar China from receiving so-called trade development assistance and ban the payment of risk insurance for investments in China. At the time the sanctions were imposed the US Trade and Development Agency had been spending about one quarter of a roughly $\$ 30$ million fund to conduct feasibility studies. The fund had meanwhile grown to $\$ 45$ million. Another sanction involved the US Overseas Private Investment Corp. which provides risk insurance to American companies investing abroad. 
In August 1994 there were unconfirmed and repudiated reports about discussions being held on lifting the barriers. (IHT 25-08-94)

\section{US sanctions on cooperation with Khmer Rouge}

The new US 1995 Foreign Operations Act carries provisions which might affect the relations between the two countries. First, a provision mandates stopping assistance to any country "cooperating tactically or strategically with the Khmer Rouge in their military operations".

Another provision concerns aid given to the Thai military under the International Military Education Training (IMET) programme, and requires the Department of State to prepare a report by 1 February 1995 "on the extent of Thai military support for the Khmer Rouge and the efforts of the Thai Government to impede support for Burmese democracy advocates, exiles and refugees". (FEER 15-09-94 p. 16)

\section{US embargo on delivery of aircraft to Pakistan}

(see: AsYIL Vol. 1 p. 271, Vol. 2 p. 286, Vol. 4 p. 508)

On the occasion of a visit by the US Defense Secretary the Pakistani Prime Minister demanded that the US either deliver the ordered fighter planes or return the $\$ 650$ million already paid by Pakistan.

[Pakistan ordered 71 F-16s in 1989 , the prepaid amount of $\$ 658$ million covering about half of them. Under the so-called Pressler Amendment the US not only suspended delivery of the planes but also kept the money and refused to return other Pakistani military equipment sent to the US for repairs] (IHT 11-01-95)

The Pakistani demand was repeated by the prime minister during her visit to the US in April 1995. The US president agreed that the demand was reasonable and promised to consult the Congress about it. (IHT 12-04-95) The first result was that aircraft parts sent to the US for repairs were being returned to Pakistan unrepaired. (IHT 19-04-95)

\section{Easing of US embargo on North Korea}

A 44-year-old US trade embargo on North Korea was eased by allowing US firms to make telephone calls to North Korea, use credit cards there and provide some banking services. In addition, American companies would be allowed to buy North Korean magnesite. (FEER 02-02-95 p. 53)

\section{Violation of UN arms embargo against Bosnia}

It was reported that with tacit US acceptance Iran had delivered large quantities of arms to the government of Bosnia since late 1994. (IHT 15/16-04-95) 


\section{Cut in aid to protest nuclear test}

Japan announced that it would cut its grant program aid by way of protest against the recent Chinese nuclear weapon test immediately after the extension of the Nuclear Nonproliferation Treaty. It was meant as a political message and would not affect Japan's huge program of low-interest loans to support China's efforts at economic reform. (IHT 23-05-95) China expressed regret for the Japanese move, warning that it would hurt bilateral ties. The Foreign Ministry spokesman said: "We are always against politicizing economic issues and linking economic cooperation with political issues as a means to exert pressure". (IHT 25-05-95)

\section{SEA TRAFFIC \\ (see also: Territorial claims and disputes)}

\section{Vessel Traffic Monitoring System for Straits of Malacca}

The Malaysian government had decided on 26 September 1994 to have a sophisticated computerized surveillance system installed to monitor the movement of ships using the Straits of Malacca. The "Vessel Traffic Monitoring System" (VTS) would be one of the biggest of its kind to be implemented in the world and would be fully operational in 29 months.

Under the VTS, computers, radar and radio stations would be installed at strategic spots along the $765 \mathrm{~km}$ waterway. Ships using the straits would be able to communicate with the centres to know the traffic situation, weather condition, movement of ships carrying dangerous cargo and other information which could help safe navigation. When fully installed, the VTS would minimize vessel collisions in the straits where 62 incidents had been reported since 1977. (NST and Star 27-09-94)

\section{Extension of traffic separation scheme in Straits of Malacca}

The three littoral states had proposed an extension of the traffic separation scheme to the IMO in March 1995, at a seminar on conservation of marine and coastal ecosystems. At present only certain stretches of One Fathom Bank, Tanjong Piai off Johor and Pulau Batu Putih (regarded as the most congested areas) are covered by the traffic separation scheme which divides the route for north-bound and south-bound ships. The proposal would cover all stretches between One Fathom Bank and Pulau Batu Putih.

Subsequently the Malaysian government announced that it would submit proposals to improve navigation in the straits in September 1995. These proposals would include extension of the existing traffic separation scheme by another 100 nautical miles, the introduction of three designated navigational routes for different types of vessels (ships on their way to Malaysian ports, ships simply passing through the straits, ships that are berthed in transitional waters), and installation of additional navigational aids like lighthouses, signal lights and radar equipment to assist ships to navigate safely. (NST 20-03 and 07-06-95) 


\section{Vessel collisions in the Straits of Malacca}

Two collisions were reported in the first half of 1995 . The first was between a Chinese vessel, MV Fei Teng, and a timber ship, Angel Endeavour, at Port Klang on 3 January. No oil spill was reported but the Chinese vessel leaked, spoiling its soya bean cargo, and caused an overpowering stench at port. The second collision, which took place about 8 nautical miles off Kuala Sepang on 25 May, was between an empty 2,027 tonne tanker, Eastern Bliss, and a 72,759 tonne bulk carrier, Samrat Ashok. Following the collision fire broke out at the Eastern Bliss. Consequent to the collision and fire, an oil slick about $1.6 \mathrm{~km}$ in diameter from the Eastern Bliss was spotted. (NST 27-05-95)

\section{Sea lanes through Indonesian archipelago}

In the wake of the Indonesian ratification of the 1982 Convention on the Law of the Sea (CLOS) the Indonesian government moved to establish at least three north-south archipelagic sea lanes: (1) Karimata Strait - Java Sea - Sunda Strait, 615 nautical miles, linking the South China Sea and Indian Ocean, not considered suitable for ships of more than 18 meter draught; (2) Makassar Strait - Lombok Strait, 660 nautical miles, linking the Pacific Ocean, Philippine waters and the Indian Ocean; (3) Maluku Sea - Banda Sea - Indian Ocean, with three branches north of Timor extending (a) west through the Ombai and Savu straits, (b) south through the Leti Strait and (c) east through the Arafura Sea.

Indonesian officials insisted that the proposed sea lanes were not directed at restricting international shipping but at putting a rein on foreign warships. As long as they do not stray more than 25 nautical miles on either side of their charted course, submarines could remain submerged and surface vessels could launch aircraft and conduct other operations. Outside the lane the rules on innocent passage would apply: this would imply prior notification, submarines must surface and show their flag, and airplanes must stay deck-bound. The CLOS does not explicitly regulate the scope of innocent passage for warships and consequently different states have different interpretations.

The Indonesian defence ministry rejected the notion that the determination of the archipelagic sea lanes had to be approved by the International Maritime Organization.

On four occasions Indonesia had sought to close its straits to foreign shipping: in 1958, 1964, 1978 and 1988. The first two incidents were in reaction to particular events involving the Netherlands and Britain. In 1988 the Indonesian armed forces announced it would close the Sunda Strait to all traffic for two 48-hour periods and the Lombok Strait for four 48-hour periods while the Indonesian navy conducted monthlong sea exercises in the Java and Flores Seas. But it was explained later that the officers concerned did so because of an inadequate understanding of the law. In 1994 Indonesia still contended that sea lanes could be closed temporarily as long as the international community is notified beforehand and an alternative route is made available. (FEER 29-12-94/05-01-95 p. 18) 


\section{SETTLEMENT OF DISPUTES}

(see: Territorial claims and disputes)

\section{SOUTH ASIAN ASSOCIATION FOR REGIONAL COOPERATION (SAARC)}

\section{South Asia Preferential Trade Association}

The SAARC member states on 1 May 1995 approved the establishment of the South Asia Preferential Trade Association (SAPTA) that would start lowering tariffs by 8 December 1995 . SAPTA would initially cover only a small number of trade items.

\section{Joint Declaration}

In a joint declaration at the end of the summit conference the member states also called for a combined battle against terrorism and demanded the elimination of nuclear weapons. (IHT 03-05 and 05-05-95; FEER 11-05-95 p. 13)

\section{SOUTHEAST ASIA COMMUNITY}

It was reported that ASEAN was considering halfway measures to involve Vietnam, Laos, Cambodia and Myanmar in joint activities before these countries become ASEAN members. One of these would be the founding of a Southeast Asia Community. In May 1994 ten countries met in Manila to draw up a manifesto for that purpose. (FEER 28-07-94 p. 24)

\section{SPACE ACTIVITIES}

\section{Chinese launches of communication satellites}

The Apstar-1 communication satellite, owned by the seven-member APT Satellite Co. consortium consisting of three Chinese government bodies, Singapore Telecom, and Thai, Sino-Macao and Hong Kong (Taiwan-backed) companies, was launched in China on 21 July 1994 before clearing from the International Telecommunication Union which was not expected before November or December 1994. The ITU procedure includes: publication of the desired orbital position, the coordination with nearby satellites (consultation with other countries whose own satellites could be affected) and listing on the Master International Frequency Register.

The projected position of the Apstar satellite was close to two other ones already orbiting over Asia: 131 degrees east longitude, between the Sakura 3A of Nippon Telegraph and Telephone Co. at 132 degrees east, and the US-based Rimsat at 130 degrees. Negotiations were held to find a compromise. Japan accused China of violating international regulations, and threatened to take appropriate measures when the satellite's relay unit would interfere with a Japanese one. (IHT 14 and 23/24-07-94; FEER 04-0894 p. $63,18-08-94$ p. 46 et seq.) 
There are other examples of satellite operators not adhering to international conventions. By carrying StarTV, Asia Satellite Telecommunications (AsiaSat) exploited a loophole in international rules meant to prevent international TV broadcasts without prior consent from governments of the receiving countries. Another example is Tonga which, while not violating the letter of ITU rules, leases its orbital slots to others (the US-based Rimsat). (FEER 18-08-94 p. 50)

The projected launch of a second Apstar satellite, built by Hughes Aircraft Co, on 26 January 1995 met with objections from the Thai Shinawatra Satellite PLC for the same reason of having a route too close to two Thaicom satellites and thus likely to interfere with their functioning. (IHT 25-01-95) The launch failed as either the satellite or the rocket carrying the satellite exploded shortly after take-off. (IHT 27-01 and 0902-95; FEER 09-02-95 p. 53) China Pacific Insurance Co. paid $\$ 160$ million in compensation to Asia-Pacific Communication Satellite Co. for the unsuccessful launch. (IHT 29-03-95)

Apstar-2 would have enabled numerous cable-television broadcasters to compete with the dominant Star-TV network in the Asia-Pacific market. Star-TV is a prime user of AsiaSat-1, owned by Asia Satellite Telecommunications Co. and launched in 1990. The latter was scheduled to have an AsiaSat-2 launched in spring 1995 by the same kind of Chinese rocket which launched the Apstar-2. (IHT 28/29-01-95)

\section{Competition in satellite-launching}

China charges much less than Western companies for a launch, causing the US to make it a trade issue. A Sino-US agreement of 1988 limited the number of Chinese launches of US-built satellites in 1994 to nine and stipulated that China charge close-tomarket prices. A new agreement was signed in March 1995. In it China agreed to conduct no more than 11 commercial-satellite launches annually over the next seven years and not to undercut Western bids for launches by more than $15 \%$. Under a similar US-Russian agreement the Russian charge should not be lower than $7.5 \%$ below the cheapest Western bid. (FEER 18-08-94 p. 48; 23-03-95 p. 63)

\section{Japanese rocket launch}

Japan launched its domestically developed H-11 rocket on 28 August 1994 after two failed launching attempts earlier in the month. The rocket, the first Japanese-made rocket able to lift heavy satellites, carried a 2-ton government satellite for telecommunications research. Previous Japanese rockets were based entirely on US designs, which gave the US veto power over all launches. (IHT 29-08-94) However, the satellite developed serious problems because of a faulty valve controlling fuel injection. (IHT 31-0894) On 31 August the effort to place the satellite into the required orbit was abandoned. (IHT 01-09-94)

SPECIFIC TERRITORIES WITHIN A STATE: EAST TIMOR (see also: Asylum) 


\section{International developments}

In his annual report to the UN General Assembly on the subject of East Timor, published on 22 September 1994, the Secretary-General recalled that the IndonesiaPortugal dialogue had been under way since 1983 and that it was reactivated towards the end of 1992 after an interruption in 1991. There had been five rounds of discussions between the Secretary-General and the two ministers for foreign affairs, the latest one held on 9 January 1995, while a sixth round would be held at Geneva on 8 July.

During the fifth round ministerial talks an All-Inclusive Intra-East Timorese dialogue was contemplated. Indonesia said on 23 March 1995 that it would not boycott the UN-sponsored talks but was disappointed over the way the UN Secretary-General had included key dissident figures without consulting Indonesia. The meeting finally took place in Salzburg, Austria, from 2-5 June. (see infra)

Although the positions of Indonesia and Portugal remained far apart a number of mutually agreed confidence-building measures, primarily of a humanitarian nature, had been carried out.

On 6 May 1994 agreement was reached on a number of steps to be undertaken by both sides, such as continuation and expansion of access to East Timor for the UN and human rights and humanitarian organizations and of visits to East Timor by East Timorese living abroad, and of East Timorese to Portugal, the exploration of ways towards facilitating an all-inclusive intra-Timorese dialogue, and a willingness to meet separately with East Timorese representatives holding opposing views on the political status of East Timor.

The Secretary-General continued to discuss with the Indonesian government the situation of East Timorese in custody and the need for taking measures aimed at their early release. In March 1994 the UN Commission on Human Rights adopted a consensus statement on the subject (UN doc. E/1994/24-E/CN.4/1994/132 para. 482, A/AC 109/2026 of 22-06-95, IHT 11-01-95, 24 and 29-03-95) and in July 1994 the Commission's Special Rapporteur on extrajudicial, summary or arbitrary executions visited East Timor at the invitation of Indonesia. (UN doc. A/49/391; FEER 14-07-94 p. $13 ; 28-07-94$ p. 18)

Portugal's persistent demand had been a referendum on self-determination for the 600,000 East Timorese, which remained unacceptable for Indonesia. (IHT 09-01-95)

\section{Intra-Indonesian efforts to solve the conflict}

In August 1994 the Roman Catholic bishop of East Timor said in an open letter that Indonesia should hold a referendum to decide the future of the territory. Failing that he proposed talks between the Indonesian government and East Timorese political parties on how to give effective autonomy to the local population. Following these moves an overseas representative of the armed resistance movement proposed a unilateral cease-fire if the Indonesian government was prepared to start talks. (IHT 20/21-08-94)

The above efforts resulted, inter alia, in a four-day All-Inclusive Intra-East Timorese Dialogue in Austria, in early June, 1995. While admitting that the talks 
would not resolve the main dispute, the Indonesian ambassador at large for East Timor expressed the hope they might improve ties, in particular over economic and cultural issues. However, a leader of the East Timorese activists insisted on a total withdrawal of Indonesian troops, and elections. (IHT 29-03, 3/4 and 05-06-95) The meeting ended with a consensus on a common declaration and on agreement to hold further meetings. In the declaration the delegates called for respect of human rights and the preservation of the cultural identity of the region. (IHT 06-06-95)

\section{The essence of the Indonesian-Portuguese conflict}

The essence of the difference of opinion between Indonesia and Portugal is Portugal's insistence that East Timor's decolonization was not completed by Indonesianrun balloting whereby - according to Indonesia - the majority of the population opted for integration with Indonesia. (FEER 20-10-94 p. 21)

\section{US suggestions on military presence in East Timor}

The US Assistant Secretary of State for human rights urged the Indonesian government to reduce the number of troops stationed in the province since, as he put it, the presence of "a fairly substantial number" of military forces "is certainly a major concern about the process of addressing this human rights question". (IHT 21-04-95)

\section{SPECIFIC TERRITORIES WITHIN A STATE: KASHMIR}

(see also: Inter-state relations: general aspects, at p. 438)

\section{Indian middle course policy}

The Indian government on 8 August 1994 pulled back its troops which had surrounded the Hazratbal Mosque in Srinagar since 1993 but at the same time decided to extend the emergency powers under which it ruled the territory for another six months. (IHT 10-08-94)

\section{Essential Indian position}

In response to a statement issued by the Organization of the Islamic Conference on Kashmir and circulated in the UN Commission on Human Rights in March 1995, India also issued a statement in which the essentials of the Indian position was defined as follows: "Jammu and Kashmir acceded to India, in accordance with the Indian Independence Act of 1947, like the other Princely States, through an Instrument of Accession duly executed by its then Ruler and accepted by the Governor-General of India. This was ratified by a popularly elected Constituent Assembly, which went on to enact a Constitution recognizing the State as an integral part of India." (UN doc. E/CN.4/1995/167) 


\section{Offer of Iranian mediation}

During his state visit to India the president of Iran on 19 April 1995 offered to mediate the Indo-Pakistani dispute over Kashmir, and said the US must not be allowed to get involved. (IHT 20-04-95)

\section{Fight against Muslim militants}

According to Indian news reports, tens of Muslim militants, or 'infiltrators' (the official Indian term for Pakistani militants and foreign mercenaries) had died in battles with Indian troops in late April 1995. More than 11,000 people had died in secessionist-linked violence in Kashmir since 1989. (IHT 27-04-95)

On 11 May 1995 Indian government forces, which had besieged the town of Charar-i-Sharief, 40 kilometres northwest of Srinagar, since March, stormed an Islamic shrine, killing dozens of Muslim separatist guerillas and destroying the religious complex. The 650-year-old mausoleum of SHEIKH NURUDDIN NOORANI, Kashmir's patron saint, and an adjacent mosque were destroyed by fire. There were contradictory explanations as to who caused the fire, the militants or the army.

The Pakistani foreign ministry stated that "The government of Pakistan condemns this act of sacrilege, which is an affront to the conscience of Muslims the world over". (IHT 12-05-95)

\section{Considerations on autonomy}

After the Charar-i-Sharief incident there were reports of the Indian government considering larger autonomy to Kashmir.

Since independence the state had a special constitutional status and the state government had wide authority in the early years after independence in 1947. Much of it was lost in a clash with the central government in 1953 and the state came progressively under control of the central government. It lost political authority altogether with the imposition of direct rule in 1990. Muslim leaders always wanted to have the state's future decided in a plebiscite supervised by the UN, an option which had been rejected by India. The Indian prime minister repeated the Indian stand (see supra, p. 492) in an interview on 17 May 1995: "Kashmir is an integral part and parcel of India. The accession is final", referring to the accession to India in October 1947 by the Hindu ruler MAHARAJA HARI SINGH, which was never accepted by Pakistan. The latter has been holding a third of Kashmir since 1947 and has demanded a right for the Muslim majority in the Indian-ruled part to choose for joining Pakistan by way of a plebiscite. (IHT 19-05-95)

[Note: Under Art. 370 of the Indian constitution the Indian parliament can not make laws for Jammu and Kashmir except in the field of foreign affairs, defence and communications. The possibility of direct rule was constitutionally limited to five years. The Indian government had to get parliament to pass an amendment to allow direct rule after 18 July 1995.] 


\section{SPECIFIC TERRITORIES WITHIN A STATE: TIBET}

\section{Government's response to referendum plan}

Chinese government officials rejected the idea of holding a referendum proposed by the Dalai Lama. Tibet was constituted as an Autonomous Region in 1965. (IHT 1603-95)

\section{TAXATION}

\section{Malaysia-Turkey taxation agreement}

Malaysia concluded agreements on the avoidance of double taxation with: Turkey (28 September 1994) and Jordan (2 October 1994). (NST 30-09 and 03-10-94; Star 2909-94)

\section{TERRITORIAL CLAIMS AND DISPUTES}

(see also: Oil and gas)

\section{Sino-Vietnamese clashes in the South China Sea}

In April 1994 an incident occurred when Vietnamese gunboats chased away a Chinese seismic research vessel which entered into a disputed oil-drilling area in the southwestern part of the South China Sea. The activities of the Chinese vessel were related to an announcement from Crestone Energy Corp. on 19 April that it was beginning work in the Wan'an Bei 21 field, awarded to it by China in 1992. (see 2 AsYIL 378) (FEER 13-10-94 p. 29)

Later two Chinese warships blockaded a Vietnamese oil drilling rig and prevented it from working in an area claimed by both countries by turning back a Vietnamese vessel which attempted to resupply the rig. The area belonged to the same 25,000 square kilometre Wan'an Bei block (Tu Chinh for the Vietnamese), about 400 kilometres off Southern Vietnam and west of the Spratly Islands.

When Vietnam awarded an oil concession in an area just west of the Wan'an Bei block to a US-Japanese group led by the US Mobil Corp., China condemned it as illegal. In the Vietnamese view both areas are on the Vietnamese continental shelf. (IHT 19-07-94)

\section{The doughnut formula for the South China Sea}

It was reported that Indonesia had put forward a proposal on the competing claims to parts of the South China Sea that became known as the 'doughnut formula'. It would divide the South China Sea by drawing a line in the shape of an elongated doughnut by projecting 320-kilometre EEZs from the shores of the following littoral states: Vietnam, Malaysia, the Philippines and Brunei. The hole of the doughnut, i.e. the middle of the South China Sea, including the disputed Spratley chain, would be discussed by 
competing claimants as an area for potential joint economic development. It was said, however, that the proposal was not widely accepted by the other ASEAN countries, and that there was reluctance from the Chinese side to discuss the legal basis of its sovereignty claims. (FEER 11-08-94 p. 18)

\section{The Mischief Reef incident and its aftermath}

On 8 February 1995 the Philippine president referred to the deployment of warships and the building of structures by China on the Panganiban Reef (also known as Meijijiao Reef in Chinese, or Mischief Reef) in the Kalayaan Island Group (those of the Spratly Islands claimed by the Philippines and within the Philippines' exclusive economic zone). Before that China already held seven reefs in the area. The actual reef is under water and surrounds a lagoon. It seemed that China had built the structures on Mischief Reef during the last monsoon season. Philippine patrols apparently had already spotted them in November 1994 but the issue was not raised publicly until February 1995.

The actions were considered inconsistent with international law and the spirit and intent of the 1992 ASEAN Declaration on the South China Sea (3 AsYIL 480). The Philippines lodged a 'strong diplomatic protest' with China. Meanwhile a group of Filippino fishermen claimed they had been detained by Chinese military on a shoal in the area for a week in January 1995. (IHT 09-02 and 17-02-95; FEER 01-06-95 p. 20)

China on 9 February denied the Philippine accusations about the erecting of large structures and said, instead, that it had merely set up shelters at Meijijiao coral reef for Chinese fishermen. China also denied that its navy had intruded into territory claimed by the Philippines and that it had detained or arrested any Filipino ship. (IHT 10-02-95; FEER 23-02-95 p. 15)

In a statement of 15 February 1995 the Philippine president introduced a new approach, proposing that every disputed island be placed " under the stewardship of the country closest to it", provided that each state then allowed anchorage and other 'peaceful pursuits' by the other claimants. He called the Chinese occupation of the disputed reef a "multilateral concern ... of all the countries interested in the long-term stability of the South China Sea and the East Asian region as a whole." (IHT 16-02-95)

On 22 February the Philippine side announced that it would build lighthouses and run naval patrols in the area. The president said that lighthouses "ensure safety at sea for all nations that pass through those waters" and "provide landmarks to where our territories are".

The two sides started talking over the issue on 20-22 March (IHT 21, 23 and 2402-95, 15 and 21-03-95) and agreed to further discussions at an unspecified date. (IHT 23-03-95)

The Philippine president announced on 29 March 1995 that the Philippine navy had destroyed Chinese structures and removed Chinese markers on the Thomas 1 and Thomas 2 shoals, Half Moon Shoal and Pennsylvania Reef. Earlier the navy had blown up Chinese markers on Jackson Atoll, Half Moon Shoal and Sabina Reef. The chief of the armed forces said that the nearest of these markers were 80 kilometres from the southwestern Philippine island of Palawan "and therefore clearly within Philippine 
territory". The latest instance of destruction of Chinese markers was reported on 15 June 1995.

A physical confrontation between China and the Philippines took place around midMay 1995, when a Philippine navy ship carrying a general and a group of journalists came to 8 nautical miles north of Mischief Reef and launched helicopter sorties. Two Chinese vessels with markings identifying them as fishing boats blocked the Philippine ship. (IHT 17-05-95, 16-06-95)

\section{US attitude vis-à-vis the South China Sea}

In a statement of 13 February 1995 the US State Department said: "Our position on this is that we don't take a position on the merit of competing claims in the South China Sea. We have stated firmly that these conflicting claims should be resolved peacefully, that we see no justification for any threat or use of military force, and that we would view the use or threat of force as a very serious matter." (IHT 15-02-95)

In the "East Asia Strategy Report" prepared by the US Defense Department it was said: "Our strategic interest in maintaining the lines of communication linking Southeast Asia, Northeast Asia and the Indian Ocean make it essential that we resist any maritime claims beyond those permitted by the Law of the Sea Convention". (IHT 28-02-95)

On 10 May 1995 the US government issued its strongest statement of concern on the Spratly dispute, calling on China and its five neighbours to "intensify diplomatic efforts" to prevent a possible outbreak of hostilities. It said that the US had "an abiding interest" in the maintenance of peace and stability in the South China Sea, adding that unhindered navigation by ships and aircraft through and above the sea was "essential for the peace and prosperity of the entire Asia-Pacific region, including the US". (IHT $13 / 14-05-95)$

\section{The ASEAN attitude}

ASEAN reacted to the Mischief Reef incident by a statement of 18 March 1995 in which the ASEAN foreign ministers expressed their "serious concern over recent developments which affect peace and stability in the South China Sea". They urged all concerned to remain faithful to the letter and spirit of the 1992 Manila Declaration on the South China Sea (3 AsYIL 480) and called upon all parties to accordingly refrain from taking actions that could "destabilize the region and further threaten the peace and security of the South China Sea". Finally they urged the countries in the region to undertake "cooperative activities which increase trust and confidence and promote stability" and encouraged "all claimants and other countries in Southeast Asia to address the issue in various fora, including the Indonesia-sponsored workshop series on managing potential conflicts in the South China Sea". On 22 March Vietnam stated it fully supported the position of the ASEAN countries as expressed in the foreign ministers' statement. (KK)

The serious concern of ASEAN over China's intentions and policy in the South China Sea as demonstrated by its recent actions on Mischief Reef was explicitly expressed at the Sino-ASEAN consultative meeting of senior officials that took place at Hangzhou on 2-3 April 1995. (ASEAN Ann. Rep.94-95 p. 60) 
In July 1995 the ASEAN Foreign Ministers expressed their concern and called on all claimants to refrain from taking actions which could destabilize the region, including possibly undermining the freedom of navigation and aviation in the affected areas. (A/50/713 paras 139-140)

\section{The nature of the Chinese claim}

It was said that at the ASEAN-China consultative meeting at Hangzhou in April 1995 Chinese officials said they were planning to modify the Chinese claim to ownership not of the entire Spratly area, but only of the islands and reefs. (FEER 0106-95 p. 20)

\section{Taiwanese policy regarding the Spratlys}

According to news reports Taiwan planned to reinforce its claims to sovereignty over the Spratly and Pratas Islands by sending armed patrol boats and erecting a marker over Taiping Island, the biggest in the Spratlys and occupied by Taiwan marines. (IHT 30-03-95)

\section{Taiwan - Vietnam}

Vietnam accused Taiwanese artillery on Ban Than atoll to have fired at a Vietnamese supply ship on 25 March 1995 when the ship passed 800 metres from the atoll, where Taiwan had started construction work.

The incident was described as a "very serious action in violation of Vietnamese sovereignty". However, the Taiwanese authorities rejected the Vietnamese protest and maintained that the island belongs to Taiwan which was justified in expelling foreign vessels from its waters. Yet it recalled patrol boats sent to the Spratlys to protect fishermen because it did not want to risk the possibility of conflict in the area.

At around the same time the Taiwanese president as well as the Chinese foreign minister called on avoiding controversy and emphasizing joint management. (IHT 0504-95)

Malaysia - China

In March 1995 Malaysia arrested the crew of a Chinese fishing boat 70 miles off Sarawak in waters claimed by Malaysia but also falling within China's claim. (IHT 0704-95)

\section{No impediment to freedom of the seas}

There were signs that the countries involved in the dispute over the Spratlys were moving towards a peaceful settlement based on the principles of international law, and particularly the CLOS. China and the Philippines reportedly agreed on a mutual code of conduct that would allow for freedom of navigation. (UN doc. A/50/713 paras 139140) 
China, responding to concern expressed by several countries, declared that its claim to the islands is not meant to impede freedom of navigation or the safe passage of aircraft and ships of other countries. The statement was the first to clarify China's claim by separating its territorial dispute from international questions of freedom of the seas. (IHT 22-05-95)

\section{Detention of Chinese fishermen in disputed area}

The Philippine navy caught 50 Chinese fishermen and detained four Chinese fishing boats who were fishing in an area of the South China Sea claimed by the Philippines, near the Arellano shoal. (IHT 27-03-95) When demanding the release of the boats and their crews the Chinese foreign ministry said that China held indisputable authority over the Spratlys and their waters. (IHT 29-03-95) The Philippine president rejected the demand, saying the fishermen had been destroying the environment and "deserve condemnation by the international community". (IHT 30-03-95) They were charged with illegal entry and poaching with explosives and cyanide. (IHT 04-04-95)

\section{Sipadan and Ligitan Islands}

(see: AsYIL Vol. 1 p. 348, Vol. 2 p. 379)

Malaysia had proposed in the Indonesia-Malaysia Joint Working Group in September 1994 that the dispute be referred to the International Court of Justice. The proposal was made because all documents and papers in support of its claim had been discussed with Indonesia during three meetings of the JWG but the dispute remained unresolved. Malaysia wanted the dispute to be resolved speedily in a just manner so that both countries could concentrate on strengthening bilateral relations. Indonesia, while not rejecting outright Malaysia's proposal, preferred to refer the dispute to the ASEAN Higher Council, set up under the ASEAN Friendship and Cooperation Agreement, on the ground that resolution of the dispute within ASEAN would reflect Southeast Asia's ability to settle its differences amicably. This was not acceptable to Malaysia: as it also had territorial disputes with other ASEAN states, the latter could rely on 'vested interests'. In a meeting with the Indonesian president the Malaysian prime minister later agreed to settle the dispute over the two islands through bilateral negotiations.

In February 1995, however, the Malaysian foreign minister suggested that the meetings be held at a higher level, involving the leaders of the two countries, since discussions at the officials' and ministerial levels had been exhausted. This initiative was taken following press reports on 9 February 1995 that the Indonesian Survey and Mapping Coordinating Unit had included the two disputed islands into the Republic's new map.

On the basis of a report prepared by the JWG the dispute was discussed for the first time by the Indonesia-Malaysia Joint Commission in June 1995. At the end of the meeting, Malaysia and Indonesia agreed to hold high-level talks between representatives of the heads of government to find a peaceful solution. No time frame was fixed for the talks. (IHT 17/18-09-94; NST 13-09 and 18-09-94, 13-02, 17-02, 26-02, 09-06 and 10-06-95; Star 08-09-94, 13-02, 17-02, 26-02, 09-06 and 10-06-95) 


\section{Pulau Batu Putih}

Malaysia and Singapore agreed in principle to refer their dispute over Pulau Batu Putih to the International Court of Justice. The agreement was reached on 6 September 1994. No agreement could yet be reached at a meeting of officials in June 1995 on the terms of reference for the special agreement required for the submission of the dispute, and another meeting on the outstanding matters was scheduled for later in the year. (NST 08-09-94, 16-06 and 17-06-95)

\section{Terumbu Layang-Layang}

The Malaysian prime minister announced on 26 May 1995 that the island of Terumbu Layang-Layang belongs to Malaysia and that its status should not be questioned by other countries. Terumbu Layang-Layang is one of the Spratly Islands and Malaysia claims sovereignty over the island because it lies within Malaysia's exclusive economic zone. (NST and Star 27-05-95)

\section{Japanese fishing in disputed territory off Northern Japan}

A Russian patrol vessel sank a Japanese fishing boat and seized its crew in disputed waters off northern Japan. Russia notified the Maritime Safety Agency of Japan about the matter. Japan protested against the incident, warning that it could harm efforts to solve a dispute over fishing rights. (IHT 06-10-94) Talks over these rights began on 13 March 1995. (IHT 14-03-95)

\section{Russian proposal on disputed Kuril Islands}

Russia proposed a plan for a free economic zone in the disputed Kuril Islands with Japanese participation, but Japan reacted coolly and said it found it difficult to accept the proposal if the islands were kept under Russian jurisdiction. (IHT 13-10-94)

\section{Gulf of Tonkin}

In October 1994 China filed an official protest with Vietnam, accusing Vietnam of "gross violations of its rights and sovereignty" in the Gulf of Tonkin. Reacting to these protests, Vietnam accused China of "systematic and unacceptable" violations in the Gulf of Tonkin, warning that it reserved the right to "defend its territorial waters". These alleged violations comprised Chinese fishing boats systematically violating the Vietnamese EEZ and territorial waters. Besides the Chinese territorial claims in the Gulf were called a violation of the UN Law of the Sea Convention and of Vietnamese sovereignty.

Vietnam ratified the 1982 CLOS in June 1994 which it says legitimizes its claim to sovereignty over areas of the gulf and the 'Eastern Sea' (known to the Chinese as the 'South China Sea'). Discussions on demarcation began in 1993 but had not resulted in a solution. Meanwhile Vietnam had begun oil exploration in the contested area in association with foreign companies. (IHT 18-10-94) 


\section{Sino-Indian territorial claims}

China claims 90,000 square kilometres in the Indian northeastern Arunachal Pradesh state. Reversely India holds the view that China occupies 33,000 square kilometres in the Aksai Chin region of Jammu and Kashmir. (IHT 17/18-12-94)

\section{Persian (Arab) Gulf Islands}

(see: AsYIL Vol. 2 p. 379, Vol. 3 p. 450)

In mid-February 1995 US news reports quoted Defense Ministry officials according to whom Iran had stationed about 5,000 troops on Abu Musa Island and the two Tunb Islands located near the Strait of Hormuz, and equipped them with missiles. Iran insisted that the measures were of a strictly defensive nature. (IHT 01 and 02-03-95)

On 22 March 1995 the US Defense Secretary accused Iran of also having moved chemical weapons to the islands, which could threaten the safety of oil shipping in the Persian Gulf. (IHT 23-03-95)

\section{Natuna Islands and Natuna gas field}

The Natuna gas field is about 230 kilometres northeast of the Natuna Islands. It lies inside the Indonesian 200-mile exclusive economic zone. Indonesia is developing it with Exxon of the US. (see: Foreign investment, supra p. 416)

At the informal 1993 workshop on the South China Sea at Surabaya a Chinese map showed the field falling under Chinese control. Indonesia had sent a diplomatic note requesting clarification of the Chinese map. It complained that in adhering to its 'historic claims' China had not clarified whether it is claiming the islands or the seabed or the water. Asked about Indonesian concerns a Chinese foreign ministry spokesman said that maritime boundaries in the South China Sea would be settled through bilateral consultations and negotiations. (IHT 12-04-95; UN doc. A/50/713 paras. 139-140) Chinese denial of the existence of any dispute with Indonesia on the Natuna Islands was repeated in June 1995, and was accompanied by an assurance that China was prepared to settle questions of demarcation by negotiation. (Kompas 23-06-95)

\section{TERRITORIAL INTEGRITY}

\section{Russian bombing of Afghan border area}

For the fourth time during the current month it was reported on 11 January 1995 that Russian jets had bombed border areas in the northern Afghan province of Badakhshan. The province borders Tajikistan, where Russia was deploying troops to help fight ant-government Islamic guerillas suspected of having bases in Afghanistan. (IHT 12-01-95) 


\section{TERRITORIAL WATERS}

(see also: Borders; Jurisdiction)

\section{Extension of Korean territorial sea}

South Korea planned to expand its territorial sea to 12 nautical miles off its southern coast. This would affect the waterway between South Korea and Japan and would consequently need bilateral consultations. The two countries currently claimed territorial zones of 3 nautical miles in the area.

The expansion would serve to protect fishing grounds from Chinese poachers. South Korean fishermen complained that some of their richest fishing grounds, including those in the Korean Strait, were being overfished by Chinese boats. (IHT 4/503-95)

\section{Malaysia-Singapore agreement on demarcation of territorial waters}

The two countries signed an agreement on the demarcation of their territorial waters on 7 October 1994, after 14 years of negotiations which commenced in 1980 when a joint hydrographic survey was conducted.

The agreement clearly defines the boundary based on precise co-ordinates in the Straits of Johor, totalling 48 nautical miles. This was done in accordance with the Straits Settlement and Johor Territorial Waters Agreement 1927, which marked the agreement between the Sultan of Johor and the Government of the Straits Settlement on the concept of a territorial waters boundary following the deep water channel. The need to delimit precisely the territorial waters boundary was recognized in late 1971, arising from concern over reclamation activities and its effects upon navigation as well as concern over pollution in the straits. (NST 15-10-94,08-08-95)

\section{TERRORISM}

\section{Muslim militants in Pakistan}

It was suspected that clandestine Muslim training centres in North-West Frontier Province in Pakistan had been used as fronts for terrorist activities abroad by Muslim militants. The international links came to light when the suspected mastermind of the 1993 bombing of the World Trade Center in New York was captured in a boarding house in Islamabad and was immediately deported to the US (see Judicial assistance).

The prime minister stated that the government favoured closing the training centres, religious schools and other similar places but would need foreign, particularly US, assistance for doing so, because such measures would prompt the militants to fan out across Pakistan. The call for help could refer to a resumption of aid programs or to persuading other states to take back their nationals who had joined activist groups in Pakistan. (IHT 23-03-95)

[Note: The above Pakistan-born suspect was said also to have made an attempt to assassinate the Pakistani prime minister, to have been involved in plotting to assassinate 
the Pope during the latter's visit to the Philippines in January 1995, and to have been involved in the bombing of a Philippine airliner on 11 December 1994 and the preparation of the bombing of two US jumbo jets near Hong Kong. IHT 27-03-95]

\section{TRANSIT}

See: Inter-state relations: general aspects, at p. 440, 442; International trade, at p. 453

\section{UNITED NATIONS}

\section{Japanese candidacy for permanent seat in the UN Security Council}

Japan announced on 13 September 1994 that it would formally seek a permanent seat on the UN Security Council, but that it would claim exemption from actions aimed at using force. (IHT 14-09-94)(see also supra, p. 435)

\section{Malaysian peace-keeping troops in Bosnia-Herzegovina}

In mid-December 1994 the Malaysian government announced that the strength of the Malaysian troops serving under UNPROFOR would be increased from about 1600 to 3000 men. However, the defence minister announced in June 1995 that the UN had rejected Malaysia's offer and would only allow an increase of between 200 to 300 men. (Star 15-12-94 and 20-06-95)

\section{ASEAN peacekeeping force for $U N$ missions}

Malaysia and Singapore agreed on the idea of an ASEAN peacekeeping force for UN missions, and to have it accepted by the other ASEAN member countries. The idea was first announced after bilateral discussions between the Malaysian and Indonesian defence ministers in November 1994. (NST 18-01-95)

\section{Status of contributions to the UN regular budget for 1995}

State

$$
\text { scale of }
$$
contribution assessments (\%) payable (\$)

$\begin{array}{llr}\text { Afghanistan } & 0.01 & 109,278 \\ \text { Bangladesh } & 0.01 & 109,278 \\ \text { Bhutan } & 0.01 & 109,278 \\ \text { Brunei Darussalam } & 0.02 & 218,556 \\ \text { Cambodia } & 0.01 & 109,278 \\ \text { China } & 0.72 & 7,868,000 \\ \text { India } & 0.31 & 3,387,611 \\ \text { Indonesia } & 0.14 & 1,529,889 \\ \text { Iran } & 0.60 & 6,556,667\end{array}$




$\begin{array}{lrr}\text { Japan } & 13.95 & 52,442,506 \\ \text { Kazakstan } & 0.26 & 2,841,222 \\ \text { Korea (DPRK) } & 0.04 & 437,111 \\ \text { Korea (ROK) } & 0.80 & 8,742,223 \\ \text { Kyrgyszstan } & 0.04 & 437,111 \\ \text { Laos } & 0.01 & 109,278 \\ \text { Malaysia } & 0.14 & 1,529,889 \\ \text { Maldives } & 0.01 & 109,278 \\ \text { Mongolia } & 0.01 & 109,278 \\ & & \\ \text { State } & \text { scale of } & \text { contribution } \\ & \text { assessments (\%) } & \text { payable }(\$) \\ & & \\ \text { Myanmar } & 0.01 & 109,278 \\ \text { Nepal } & 0.01 & 109,278 \\ \text { Pakistan } & 0.06 & 655,666 \\ \text { Papua New Guinea } & 0.01 & 109,278 \\ \text { Philippines } & 0.06 & 655,666 \\ \text { Singapore } & 0.14 & 1,529,889 \\ \text { Sri Lanka } & 0.01 & 109,278 \\ \text { Tajikistan } & 0.03 & 327,833 \\ \text { Thailand } & 0.13 & 1,420,611 \\ \text { Turkmenistan } & 0.04 & 437,111 \\ \text { Uzbekistan } & 0.19 & 2,076,278 \\ \text { Vietnam } & 0.01 & 109,278 \\ \text { (UN doc. ST/ADM/SER } & \text { B/480) }\end{array}$

(UN doc. ST/ADM/SER.B/480)

\section{Increase of Korean contribution}

According to the foreign ministry of the Republic of Korea the country would increase its contribution to the UN to about $\$ 48$ million to reflect its growing role as a world-class economy. (IHT 13-04-95)

\section{UNRECOGNIZED ENTITIES}

\section{North Korea-Taiwan contacts}

It was reported that North Korea had stepped up contacts with Taiwan in the past year. Among the visitors arriving in Taiwan were those coming from the Korean National Development Committee, a semi-official agency. (FEER 21-07-94 p. 12)

\section{US policy vis-à-vis Taiwan}

On 7 September 1994 the US announced a change in Taiwan policy, reaffirming the US position that there is only 'one China', but loosening some of the strictures that 
had prevented US officials from carrying out direct talks with Taiwanese officials on trade and economic issues. For the first time since 1979 the most senior US official in Taiwan visited the Taiwan president to brief him on the policy change.

The adjustments included permission for cabinet-level visits, allowing a more suitable title for the Taiwanese representative office in the US, and allowing Taiwanese officials as such to visit US government offices. (IHT 09 and 12-09-94; FEER 21-0794 p. 20)

\section{Visit to the US by Taiwanese president}

In response to an invitation to the Taiwan president by Cornell University in the US to address an alumni function in June 1995 the US Senate Foreign Relations Committee and the US House International Affairs Committee approved resolutions in March and April 1995, urging an end to a long-standing restriction on visits from Taiwan leaders. (IHT 07-04-95)

On 9 May 1995 the US Senate approved a resolution with 97 to 1 vote calling on the president to allow the visit, after a similar resolution was adopted unanimously by the House of Representatives on 2 May. State Department officials said, however, that despite the Senate vote the administration would not grant a visa, and that the visit was not worth touching off a major dispute with China. A State Department spokesman said that the administration was not rethinking its position and that allowing the visit would be seen by China "as removing an essential element of unofficiality in the US-Taiwan relationship" and "would have serious consequences for US policy".

However, under intense pressure from the US Congress the US president on 20 May 1995 decided to grant a visa, thus breaking a 16-year policy and a commitment of September 1994 in which the US government assured the Chinese government that only transit stops for safety, comfort or convenience would be allowed.

[Under the 1994 upgrading of unofficial relations with Taiwan (see supra) the aircraft of the Taiwanese president could make brief transit stops in the US "for safety, comfort and convenience", as it did in 1994 for refuelling at Hawaii.] (IHT 12 and 23-05-95; FEER 25-05-95 p. 13)

\section{Australian position regarding visa for Taiwanese officials}

The Australian foreign minister told Parliament that the government was not contemplating allowing the Taiwanese president, nor for that matter the Taiwanese prime minister, to visit Australia, whether officially or otherwise. The response was given with regard to an invitation extended to the Taiwanese president to address the National Press Club in Canberra. The statement said, inter alia: "It has been the policy of the Australian government to restrict private visits to Australia by high-level officials from Taiwan to those which are strictly related to the promotion of our strong and expanding economic and trade interests". (IHT 30-05-95) 


\section{Meeting of Czech prime minister with Taiwanese prime-minister}

The prime minister of the Czech Republic met with the Taiwanese prime minister in Prague on 19 June 1995 during the latter's European tour. The meeting was classified as unofficial, informal. (IHT 20-06-95)

(NON-)USE OF FORCE

(see: Inter-state relations: general aspects)

\section{VIETNAM WAR}

\section{Number of victims}

According to incomplete figures, released by the Vietnamese government, more than 1 million soldiers and about 2 million civilians were killed from 1954 to 1975 . Another 300,000 soldiers were listed as missing and 600,000 had been wounded. Two million Vietnamese were left invalid, and nearly as many suffered from the effects of chemical defoliants used by US forces. Besides, according to US statistics 200,000 South Vietnamese troops died and 500,000 were wounded. (IHT 05-04-95)

\section{WEAPONS}

(see also: Inter-state relations: general aspects, at p. 438; Nuclear capability)

\section{Sino-US agreement on production of nuclear weapons}

On 4 October 1994 China and the US issued a joint statement pledging to work together to promote "the earliest possible achievement" of an international convention "banning the production of fissile materials for nuclear weapons". (FEER 20-10-94 p. 20)

\section{Indian attitude toward NPT}

India stated that it was prepared to meet the efforts for extending the NPT part of the way: it would ban further production of fissile materials as long as all others do the same. A convention on the matter would ban further production of highly enriched uranium or plutonium. In this respect India and the US shared the same view, and it was in accordance with India's long-standing view that non-proliferation regimes should apply equally to all countries.

India had so far resisted signing the NPT because it is flanked by China and it is in a stalemate with Pakistan. India wanted the five nuclear powers to commit themselves to deadlines for disarmament. (FEER 02-02-95 p. 16) 


\section{Indonesian attitude toward NPT}

The Indonesian foreign minister said that the Indonesian opposition to the extension of the Nuclear Non-proliferation Treaty was not final, and that members of the Nonaligned Movement were still considering whether or not to support the indefinite extension. (IHT 22-02-95)

\section{WORLD TRADE ORGANIZATION}

(see also: International trade, supra, p. 447, 451)

\section{US complaint against South Korea on quarantine}

The US filed a complaint with the WTO for mediation in a quarrel over South Korean quarantine procedures to inspect a shipment of American grapefruit for harmful chemical residue. These procedures were newly introduced and allowed for "first quarantine and later inspection", reversing the order under prior rules. South Korea said the new procedure was intended to protect consumers. (IHT 07-04-95)

The US had also asked for WTO-sponsored consultations with South Korea to demand changes in its shelf-life rules for imported meat products. (FEER 25-05-95 p. 48)

\section{Singaporean complaint against Malaysia}

Singapore filed a complaint for being hurt by Malaysian restrictions on imports of plastic resins. The sole local producer of polyethylene is Titan, a Taiwanese-Malaysian petrochemicals plant that started production in 1991; it is also one of only two local producers of polypropylene. Titan was initially protected by a $30 \%$ duty on resin imports. When foreign suppliers remained competitive the Malaysian government introduced a non-tariff barrier - the import permit. In addition it decreed that all permit applications had to be accompanied by a 'no objection' letter from Titan. (FEER 26-0195 p. 44)

\section{WORLD WAR II}

\section{Japanese compensation for Asian war victims}

On 31 August 1994 Japan officially announced a 10-year, \$1 billion program that would provide symbolic compensation for women used as prostitutes by the Japanese army during the war. It would also refer to Taiwanese conscripts whose savings were confiscated and South Korean labourers who were marooned on Sakhalin Island after the war. The money would be used for the construction and operation of vocational centres for women in several Asian countries, as well as for additional research on World War II. The program marked a major reversal in Japan's position. For years 
Japan maintained that the issue of wartime compensation had been completely settled by the 1951 peace treaty.

Besides it was possible that a privately financed endowment of $\$ 100$ million would be set up that would make payments directly to victims. the grants would be classified as 'gifts of atonement', not compensation for sexual slavery. (IHT 31-08-94) The fund was actually established in June 1995 under the name "Asian Peace and Friendship Foundation for Women". (IHT 15-06-95)

It was reported that the Japanese scheme was not favourably received by the public in several countries, such as South and North Korea and the Philippines. According to adversaries the program is an attempt by Japan to avoid legal responsibility for its actions by offering only symbolic compensation to the victimized women. (IHT 19-0794, 31-08-94, 3/4-09-94) In February 1995 supporters and survivors of some 200,000 Asian women who were forced into prostitution by the Japanese army held a conference in Seoul, rejecting 'sympathy money' and pushing the Japanese government to pay direct compensation in order to "restore the honour" of the women involved. (IHT 2802-95)

On 6 December 1994 the Japanese government officially decided to make no direct government payments to compensate 'comfort women' and would only finance the previously announced $\$ 1$ billion program. (IHT 07-12-94)

\section{Taiwan fixed-debt problem}

The Taiwan fixed-debt problem involves the unpaid wages and frozen post-office savings accounts of Taiwanese soldiers who served in the Japanese Imperial Army.

A panel of Japanese and Taiwanese politicians met in March and June 1994 to try to reach a settlement but failed to bridge a gap of more than 3 trillion yen ( $\$ 30$ billion). Japan wants to settle the debt on the basis of the original sums due, plus interest and an allowance for inflation. Taiwan argues that the Taiwanese soldiers should be accorded the same status as soldiers in Japan's post-war Self-Defence Forces and should be compensated accordingly. That would mean multiplying the original debt by about 7,000 times, or roughly equivalent to Japan's defence budget.

Initially the government at Taiwan refused to have anything to do with Taiwanese veterans' claims as it felt "not obliged to help people who had helped the enemy". The turning point came in the early 1980 s, when democratization unleashed popular pressure on the government to admit and to actively encourage war claims against Japan. From the Japanese side the Supreme Court ruled in 1982 that Taiwanese soldiers were entitled to compensation. (FEER 20-10-94 p. 24)

On 21 December 1994 Japan announced it would spend 35 billion yen ( $\$ 350$ million) over the next five years to settle World War II debts to people from Taiwan. Claims included military pay-checks owed to conscripts from Taiwan who fought for Japan and money in postal savings accounts that was never paid back. However, the interest groups involved denounced the amount as insulting. (IHT 22-12-94) 


\section{Lawsuit by Chinese victims}

Thirty-six Chinese victims of World War II on 26 April 1995 filed a lawsuit in Tokyo against the Japanese government and Japanese conglomerates, demanding an apology and compensation.

The Chinese state had taken the position that it would not seek war indemnities but would not stop private individuals from demanding compensation. (IHT 27-04-95)

\section{Gas weapons left from the war}

Japan was to send a study team to southern China in late February 1995 to start sealing or dismantling chemical bombs left there in World War II. New documents were said to show that Japan produced more than 5 million gas shells and grenades by the end of the war. The report could shed light on poison gas shells left in China by retreating Japanese troops, an issue currently under discussion by the two governments. (FEER 23-02-95 p.13; IHT 25-05-95)

\section{Japanese apologies for the war}

At the insistence of the Japanese prime minister, the Japanese Parliament passed a resolution on 9 June 1995, expressing an apology for Japanese conduct relating to the war. The resolution was directed principally at Asian countries that were invaded by Japan, to mark the 50th anniversary of the end of the war. The relevant paragraph of the resolution has been translated in various ways:

"Recalling many colonial rules and acts of aggression in the modern history of the world, we recognize and express deep remorse for those acts our country carried out in the past and unbearable pains inflicted upon people or: abroad, particularly people of Asia",

"While giving thought to the many acts of colonial control and aggression that have occurred in modern world history, we recognize the acts of this kind carried out by our country in the past and the suffering that we caused the people of other countries, especially those of Asia, and we express our feeling of deep remorse", or:

"Recalling many aggressive-like acts and instances of colonial rule in modern world history, we recognize and express deep remorse for these kinds of actions carried out by our country in the past. They brought unbearable pain to people abroad, particularly in Asian countries".

(IHT 07, 08 and 10/11-06-95) 